UNIVERSIDADE DE SÃO PAULO

INSTITUTO DE FÍSICA

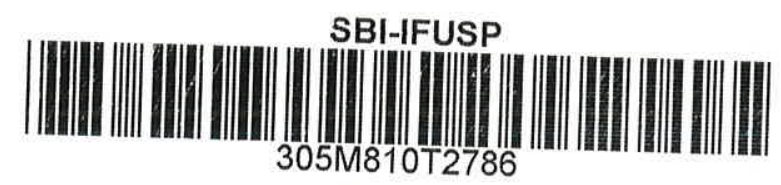

\title{
CRESCIMENTO EPITAXIAL POR FEIXE MOLECULAR DE CAMADAS PARA APLICAÇÃO EM DISPOSITIVOS
}

\author{
ALEXANDER LUZ SPERANDIO
}

Comissão examinadora:

Prof. Dr. Alain André Quivy (Orientador)

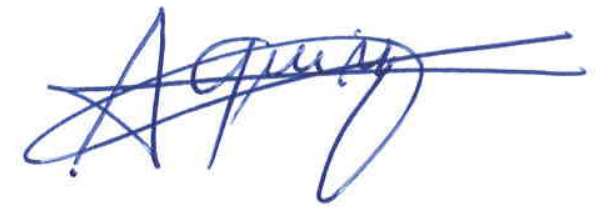

Profa. Dra. Maria Cecília Barbosa S. Salvadori

Prof. Dr. Mauro M. Garcia de Carvalho Júnior

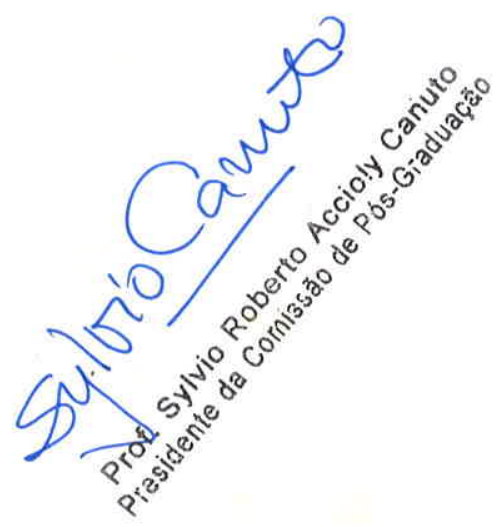

Dissertação apresentada ao
Instituto de Física da
Universidade de São Paulo
para a obtenção do título de
Mestre em Ciências

São Paulo

- 1998 -

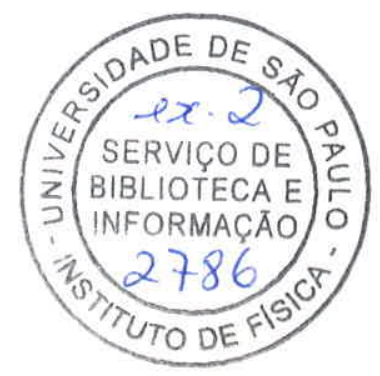


FICHA CATALOGRÁFICA

Preparada pelo Serviço de Biblioteca e Informação do Instituto de Física da Universidade de São Paulo

Sperandio, Alexander Luz

Crescimento Epitaxial por Feixe Molecular de Camadas para Aplicação em Dispositivos. São Paulo, 1998.

Dissertação (Mestrado) Universidade de São Paulo. Instituto de Física - Departamento de Física dos Materiais e Mecânica.

Orientador: Prof. Dr. Alain André Quivy Área de Concentração: Física dos Materiais

Unitermos: 1. MBE; 2. AIGaAs/GaAs; 3. Dopagem; 4. Dispositivos. 


\section{AGRADECIMENTOS}

Aos meus pais Maria de Lourdes e David, e ao meu irmão Charles, pela dedicação e carinho em todos esses anos de vida;

Aos meus tios e primos pelos alegres momentos: Emmanoel, Marilia, Ana, Gilberto, Bento, Aristides, Norma, Olegário, Valéria, Adriana, Tatá, Fabrício e os demais...

Ao meu orientador e amigo Prof. Alain Quivy, pelo grande apoio e dedicação nesta jornada de trabalho, que muito contribuiu em meu aprendizado;

À Profa. Euzi pelos momentos de discussão, esclarecendo muitas das minhas dúvidas;

Ao Prof. José Roberto Leite, chefe do grupo LNMS;

À Enza, pela dedicação com que sempre nos atendeu;

Aos amigos do grupo LNMS pela grande convivência e alegrias compartilhadas: Malinha, Lara, André, Negão, Mike, Tabata, Marcos, Pimenta, Sacha, Thomás, Ademir, Geraldão, Paulinho, César, Nilo, Valtão, Antônio, Renata, Adriano, Rogério (MBE) e os demais;

Aos amigos do apto. 206, CRUSP, pelos anos de solidariedade: Wagner, Rogério, Edvaldo, Fernando;

Ao Wagner, pela amizade que perdura desde a graduação na UFMS e que me proporcionou muitas felicidades e reflexões;

Ao Mike e Rogério pelas correções em meu trabalho com grande zelo;

Ao Marcos pelas fotos;

A Jô, pelos vários anos de carinho e cumplicidade; 
$\dot{A}$ todos os amigos do Instituto, que tive a felicidade de conhecer;

Ao $\mathrm{CNPq}$, pelo apoio financeiro;

E principalmente à Deus, que me proporcionou toda essa alegria. 


\begin{abstract}
In this work, we studied the growth of III-V semiconductor compounds by molecular beam epitaxy (MBE). Much effort was initially spent to understand the functioning of the whole system and optimize the use of some specific instruments available for in situ characterization. We gave some emphasis to the homogeneous doping of p-type layers using two new techniques and, for the first time, a thick p-type GaAs layer was successfully grown using co-evaporation of $\mathrm{Si}$ atoms on top of (001) GaAs substrates. Finally, layers with high electron mobility were obtained, as well as distributed Bragg reflectors (DBRs) showing high reflectivity. These two types of structures have many applications in microelectronics and optoelectronics industry.
\end{abstract}




\section{RESUMO}

Neste trabalho, estudamos o crescimento de camadas semicondutoras de compostos III-V pela técnica de epitaxia por feixe molecular (MBE). Um grande esforço foi inicialmente realizado para entender o funcionamento do sistema inteiro e otimizar o uso de cada instrumento disponivel para a caracterização in situ. Demos uma ênfase particular ao estudo da dopagem homogênea de camadas do tipo $p$ usando duas novas técnicas e, pela primeira vez, obtivemos com sucesso camadas do tipo p crescidas pela co-evaporação de átomos de Si sobre substratos de GaAs(001). Finalmente, camadas de alta mobilidade eletrônica foram conseguidas, assim como espelhos de Bragg (DBRs) de alta refletividade. Estes dois tipos de estrutura possuem numerosas aplicações na indústria da microeletrônica e optoeletrônica. 


\section{ÍNDICE}

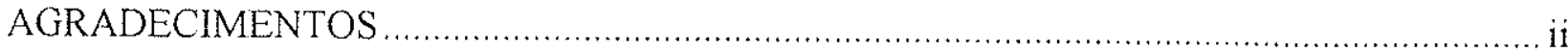

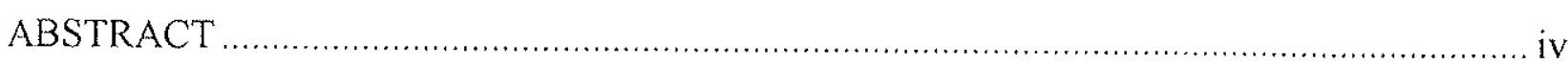

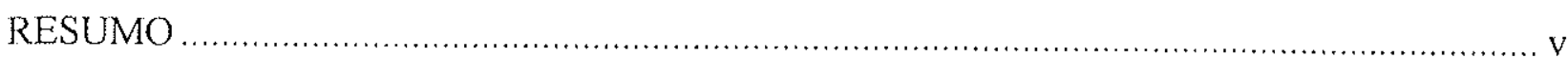

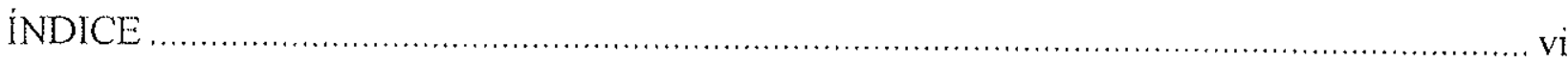

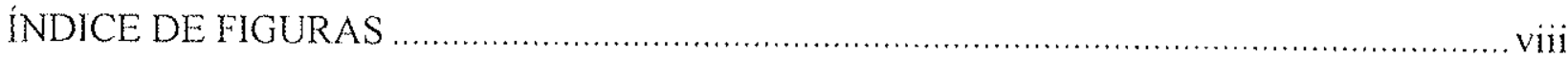

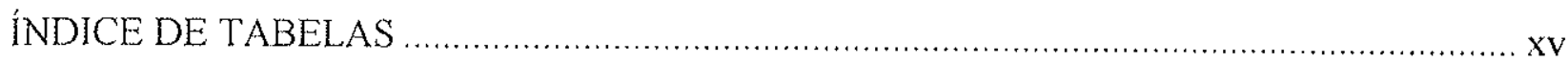

INTRODUÇÃO

1-O sistema de crescimento epitaxial por feixe molecular 1

I.1 - Descrição geral do sistema ....................................................................................... I

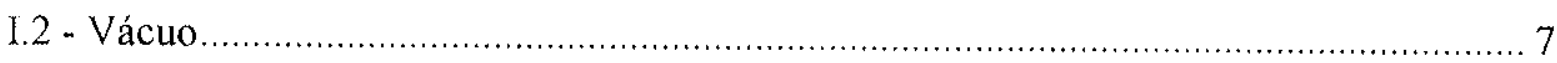

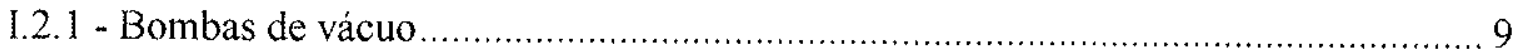

I.2.1.1 - Bomba Ventury (ar comprimido) …………............................................

I.2.1.2 - Bomba de adsorção................................................................................... 10

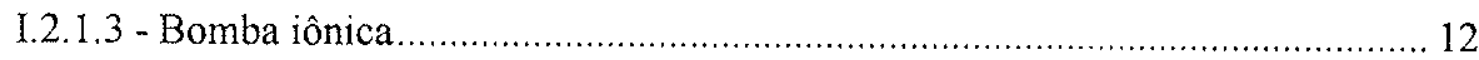

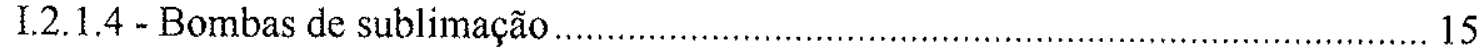

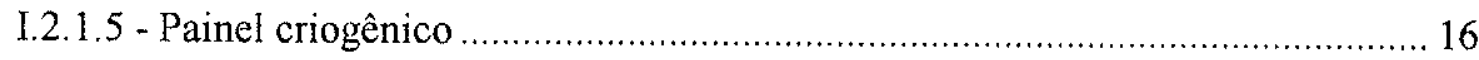

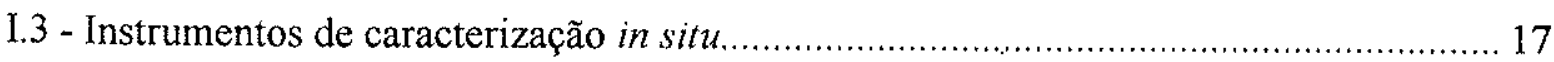

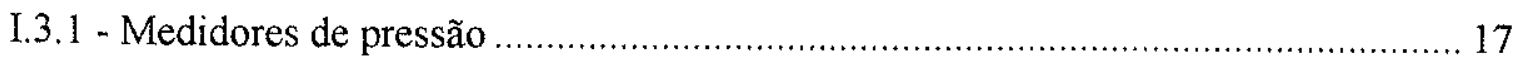

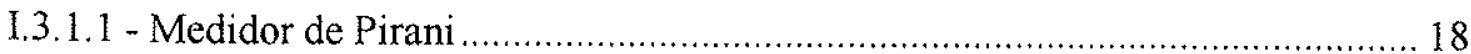

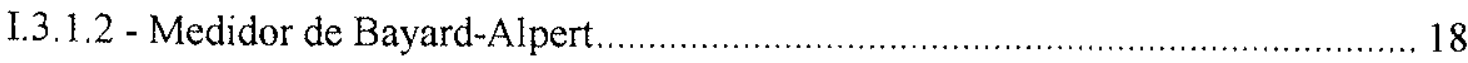

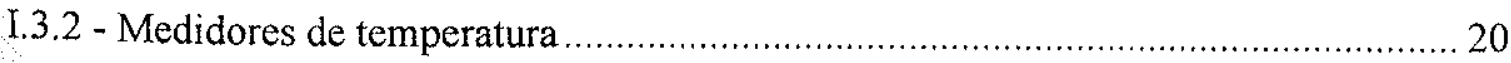

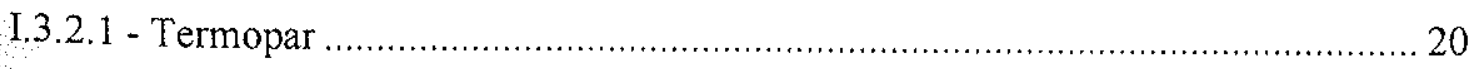

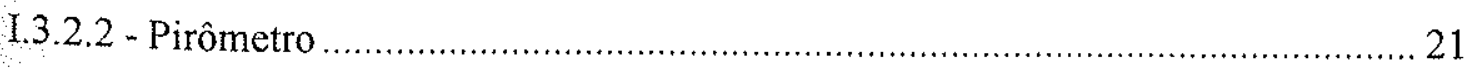

1.3.3 - Espectrômetro de massa quadrupolar.................................................................. 22

1.4 - Células de efusão de Knudsen................................................................................ 24

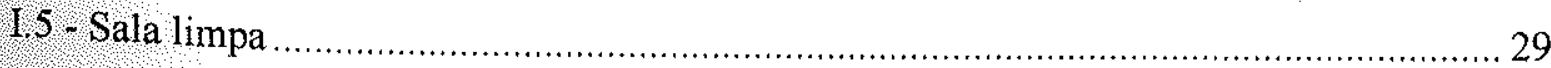

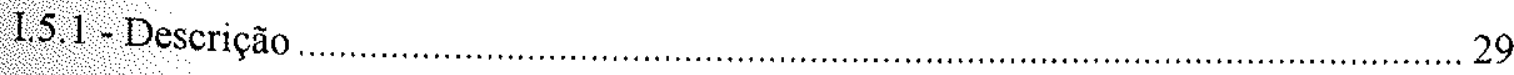

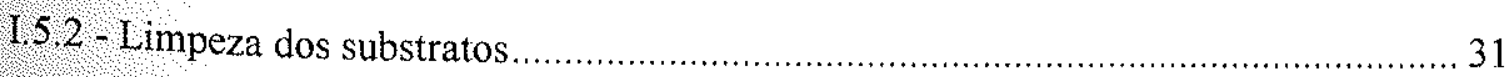

I.5.3 - Limpeza dos blocos de molibdênio ................................................................... 32

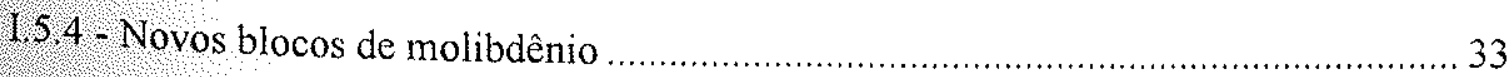

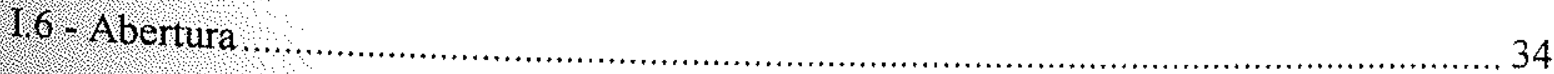




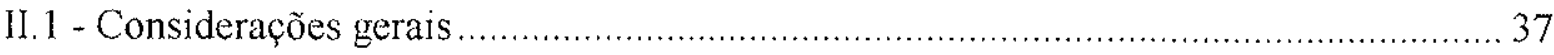

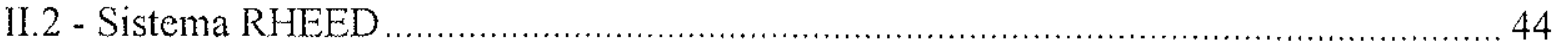

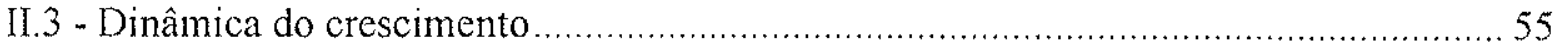

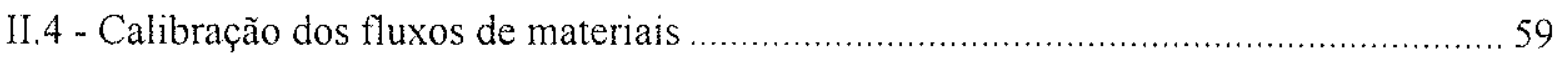

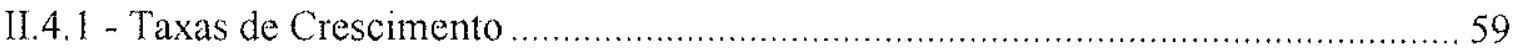

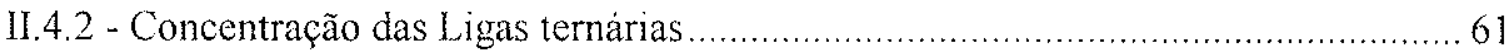

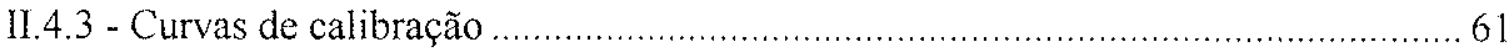

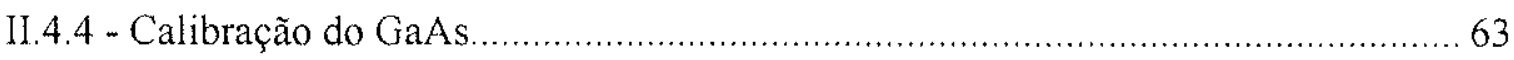

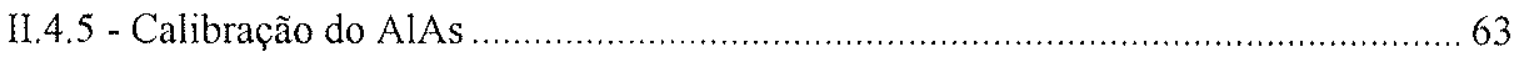

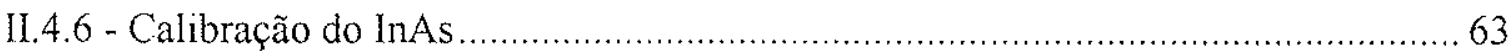

III - Otimização dos parâmetros de crescimento de GaAs e $\mathrm{Al}_{2} \mathrm{Ga} a_{1 \times}$ As 65

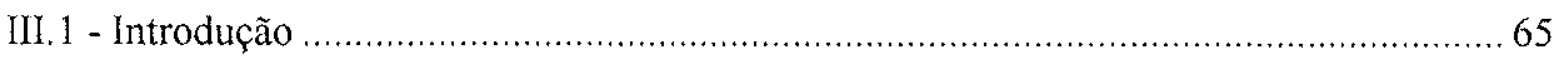

III.2 - Razão de fluxo dos elementos das famílias V e III............................................ 66

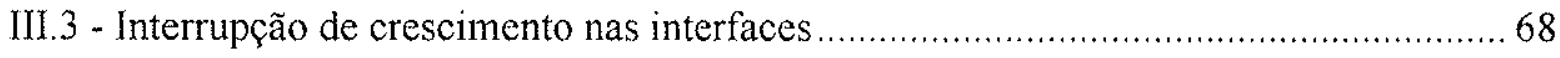

IV - Crescimento de camadas dopadas 72

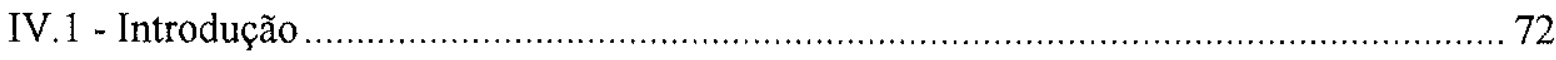

IV.2 - Incorporação não intencional de impurezas ...................................................... 73

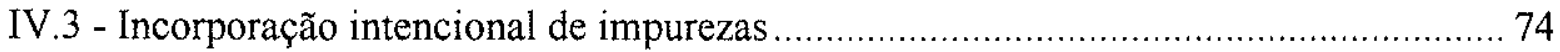

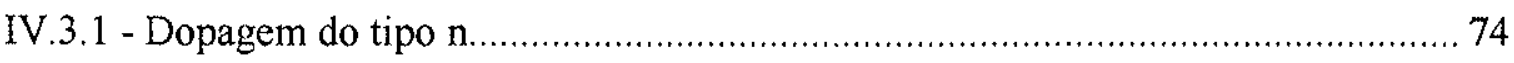

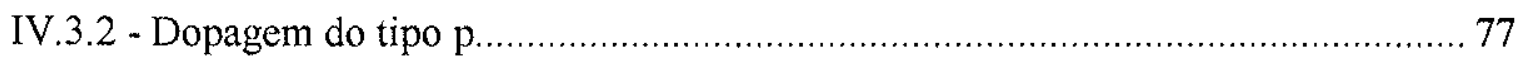

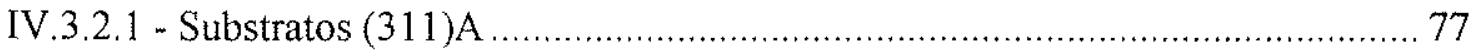

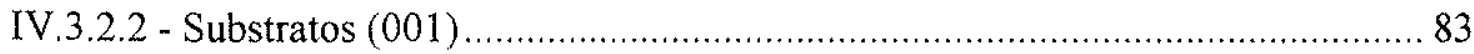

$\underline{V}$-Camadas epitaxiais para dispositivos eletrônicos e optoeletrônicos $\quad 88$

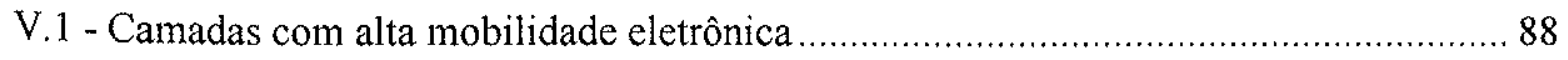

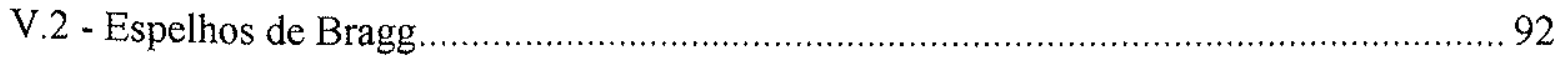

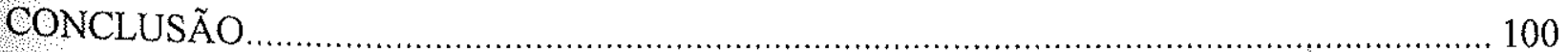

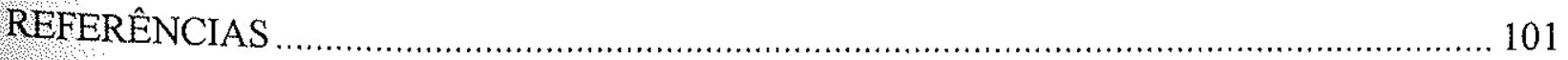




\section{ÍNDICE DE FIGURAS}

Figura 1-1 - Esquema do sistema MBE do LNMS-IFUSP com algumas de suas características; as câmaras são construídas em aço inoxidável e isoladas entre si por válvulas do tipo gaveta; o sas de entrada da câmara de entrada/saída abre dentro de uma sala limpa. 1

Figura 1-2 - Carrinho de amostras ("trolley") usado em nosso sistema, mostrado sobre o trilho da câmara intermediária; o carrinho possui capacidade para 16 blocos de Mo de 3 " cada e se movimenta através de imãs (as meia luas na parte superior do carrinho ${ }^{10}$...... 2

Figura I-3 - Detalhes das câmaras intermediária (lado esquerdo da figura, com a câmara de crescimento ao fundo) e de entrada/saída (à direita); a)válvula gaveta que separa as duas câmaras; b)válvula gaveta entre a câmara de entrada/saída e sua bomba iônica; c)conexões com as para bombas Ventury e de adsorção; d)bomba iônica da câmara intermediária; e)um dos transferidores; f)janela de observação.

Figura l-4 - Interior da câmara de crescimento de nosso sistema MBE; uma válvula gaveta separa as câmaras de crescimento e intermediária; o painel criogênico cerca a região dos fluxos; o medidor de pressão fora dessa região mede a pressão do gás residual na câmara, enquanto que o outro (a $180^{\circ}$ do porta-amostras) é usado como medidor de fluxo, quando estiver na posição do substrato.

Figura I-5 - Foto da câmara de crescimento, com vista das células de efusão de a)Si, b)As, c)Al e d) $\mathrm{Ga}$; continuando em sentido horário, temos as outras células de $\mathrm{Ga}$, In, As e Be, não mostradas na foto; e)tela fluorescente do sistema RHEED, f)espectrômetro de massa........ 5

Figura 1-6 - Fotos do conjunto sustentando o forno da amostra; a)vista da peça por inteiro, onde pode-se ver a flange (1), os eixos de rotação (2) e o porta-amostras (3); b) detalhes da parte superior, mostrando a parte externa do forno (3), as engrenagens para a rotação (4) e a posição do medidor de fluxo (retirado no momento da foto) (5) ....................................... 7

Figura 1-7 - Esquema de operação de uma célula de Penning; K1 e K2 são os cátodos de Ti, A é o ânodo cilíndrico e B o campo magnético gerado por um imã permanente externo; a trajetória dos elétrons e íons é também mostrada; o bombeamento por adsorção do gás no filme de Ti ocorre em A e nos extremos de K1 e K2; o bombeamento por implantação no cátodo acontece na região central (em $\mathrm{Z}$ ) onde acontece o sputtering do $\mathrm{Ti}$ - cratera Iustrada em K2.

Figura 1-8 - Esquema mostrando a construção de uma bomba iônica do tipo diodo, formada por um conjunto de várias pequenas células de Penning para aumentar a eficiência do 
bombeamento $^{17} ; 1$ e 2 são as placas do cátodo de Ti, e B o campo magnético produzido por um imã permanente externo.

Figura I-9 - Esquema de operação de uma bomba iônica do tipo triodo ${ }^{17}$; A - o ânodo e F - o coletor, são aterrados; $\mathrm{K}$ é o cátodo, na forma de grade e B é o campo magnético na direção $Z$; o Ti é renovado com freqüência nas superfícies de $\mathrm{A}$ e $\mathrm{F}$, pelos choques dos íons formados no ânodo, com a grade $\mathrm{K}$; a perda de energia cinética com os choques, reduz a liberação dos gases inertes, pela implantação em $\mathrm{F}$, tornando o bombeamento mais eficiente.

Figura $1-10$ - Os dois tipos de bombas de Ti utilizadas em nosso sistema: (a)a bomba da câmara intermediária com três filamentos; (b)bola de Ti(1) e escudo(2) da câmara de crescimento; devido ao uso freqüente e proximidade da bola, o escudo é resfriado pelo sistema de água em circuito fechado.

Figura l-11 - Fotos mostrando os dois painéis criogênicos independentes de nosso sistema; (a)painel que circunda a região de crescimento(1); o canhão de elétrons do sistema RHEED(2) e a flange do manipulador de substratos(3) são mostrados como referência; (b)flange dos fornos (de 18"), mostrando o segundo painel criogênico(1) e os obturadores $\operatorname{dos}$ fornos(2).

Figura I-12 - Esquema mostrando o princípio de operação do medidor por condutividade térmica (medidor de Pirani); o fio tem um diâmetro $2 \mathrm{r}_{1} \sim 5-20 \mu \mathrm{m}$ e comprimento $1 \sim 50-100 \mathrm{~mm}$ e é esticado dentro de um tubo cilíndrico de diâmetro $2 \mathrm{r}_{2} \sim 20-30 \mathrm{~mm}$. 18

Figura I-13 - Princípio de operação de um medidor de vácuo por ionização; K é o cátodo termoiônico, A o ânodo e C o coletor.

Figura I-14 - Esquema dos medidores de Bayard-Alpert utilizados em nosso sistema - modelo com flange; notar a diferença de configuração com o medidor padrão (Figura I-13).

Figura l-15 - Esquema do funcionamento de um termopar; A e B são os dois fios de materiais diferentes que formam a junção e $\mathrm{V}$ é o voltímetro para medir a diferença de potencial que é função da diferença de temperatura entre as duas junções.

Figura 1-16 - Esquema mostrando a refletividade das superficies de um mesmo material A; em (a) a superfície polida possui alta refletividade, portanto baixa emissividade $\varepsilon_{1}$; em (b), a superficie apresenta menor refletividade e portanto, emissividade $\varepsilon_{2}>\varepsilon_{1}$; em (c) a superfície possui uma refletividade muito pobre se aproximando de um corpo negro onde $\varepsilon=1$.....21

Figura 1.17 . Esquema dos três estágios de um espectrômetro de massa quadrupolar; o estágio lonizador, do tipo Bayard-Alpert, é composto unicamente dos filamentos e da grade; a 
região de filtragem é composta de 4 cilindros dispostos simetricamente, que produzem o campo eletromagnético através de voltagens continuas e de radiofreqüência e seleciona os ions; e o detector, que coleta os ions selecionados e amplifica o sinal.

Figura I-18 - Os três estágios do espectrômetro de massa quadrupolar; no ionizador(a), os filamentos termoiônicos emitem elétrons, que passam pela grade (positiva), ionizando os elementos em seu interior que são levados à placa de focalização para a região de filtragem(b); nesta região, os íons são selecionados pela aplicação de voltagens combinadas, e apenas os íons com uma certa razão massa/carga são estáveis na trajetória e chegam ao detector(c); nele, os íons entram em uma eletromultiplicadora que amplifica o sinal de entrada.

Figura 1-19 - Espectro típico, como observado em um osciloscópio, dos vários elementos no interior da câmara de crescimento, durante o crescimento; a altura dos picos é relacionada com a abundância de cada elemento na câmara; o eixo x, mostra a razão massa/carga do elemento; assim, o pico 18 corresponde ao $\mathrm{H}_{2} \mathrm{O}^{+}$e o 28 corresponde aos elementos $\mathrm{CO}^{+}$e $\mathrm{N}_{2}^{+}$

Figura 1-20 - Gráfico, em coordenadas polares, da distribuição angular das partículas do gás no processo de efusão, segundo o modelo de Clausing; o reservatório é uma célula cilíndrica com um orifício de dimensão $d_{0}$ em uma parede de espessura $L_{0}$; para $L_{0}=d_{0}$ (linha contínua), a distribuição das partículas não obedece a lei cossenoidal (linha pontilhada). . 25

Figura I-21 - Distribuição angular, em coordenadas polares, da efusão, a partir de um reservatório cilíndrico, com $L_{0}$ variando a medida que o conteúdo do reservatório vai evaporando; nota-se que o ângulo sólido se torna cada vez menor devido ao aumento de $\mathrm{L}_{0}^{26}$

Figura I-22 - Perfil da distribuição do feixe em função da forma do cadinho e da quantidade de material restante $\left(F_{1}\right.$ e $F_{2}$ indicam o nível de material no cadinho); pode-se ver que, com o cadinho completamente cheio $\left(F_{1}\right)$ o perfil é o mesmo para os dois modelos, enquanto que em $F_{2}$, com o cadinho parcialmente preenchido, a uniformidade da amostra em (a) passa a ser comprometida devido à influência crescente das paredes do cadinho.

Figura 1-23 - Esquema das células de efusão utilizadas em nosso sistema; (1)cadinho cônico de PBN que contém o material a ser evaporado; (2)os filamentos de tântalo (em vermelho) para o aquecimento; (3)camadas de tântalo para o isolamento térmico; (4)o termopar, tocando o fundo da célula, é fixado a um sistema de molas; (5)folha de tântalo da parte externa da célula; (6)flange de $4,5^{\prime \prime} ;(7)$ conector elétrico; (8)conector para o termopar. ... 28 
Figura 1-24 - Foto do interior da sala limpa do LNMS, usada para a preparação e colagem das amostras e limpeza de instrumentos, antes de serem inseridos no sistema MBE; são mostrados os fluxos laminares no teto da sala; (a)capela, com um fluxo laminar no teto e um exaustor na parte inferior; (b)filtro para o estágio final de deionização da água; (c)extremo da câmara de entrada/saída com o sas.

Figura 1-25 - Preparação de um substrato inteiro com os novos blocos de molibdênio; (a)o substrato é colocado, com a face para baixo, sobre o novo bloco; (b)colocação do anel de pressão - nessa configuração, não é mostrada a placa de safira; (c)o resultado final, com a face da amostra para cima ${ }^{35}$.

Figura 1-26 - Fotos mostrando a máquina MBE (a)em operação e (b)em baking, com os painéis para o aquecimento e isolamento térmico.

Figura II-1 - Representação esquemática dos três modos de crescimento de cristais ${ }^{42}$; (a)camada por camada (2d) ou modo de Frank-van der Merwe; (b)camada por camada seguido de ilhas ou modo de Stranski-Krastanov; (c)crescimento por ilhas (3d) ou modo de Volmer-Weber. $\theta$ representa o número de monocamadas depositadas sobre o substrato. 40

Figura II-2 - Esquema mostrando a estrutura zincblende do GaAs; sendo a o parâmetro de rede da célula convencional, observa-se que, na direção [001], a distância entre duas monocamadas é igual à metade do parâmetro de rede.

Figura II-3 - Esquema da superfície de um substrato desorientado de GaAs; $\theta$ é o ângulo de desorientação que origina uma densidade de terraços de largura $l$ e altura h igual à distância entre duas monocamadas - a/2, na direção [001].

Figura II-4 - Modelos de incorporação das moléculas de (a)As $\mathrm{A}_{2}$ e (b) $\mathrm{As}_{4}$ sobre uma superfície rica em gálio.

Figura II-5 - Reflexão de Bragg de uma família particular de planos da rede separados por uma distância d; os raios incidentes e refletidos são mostrados para os dois planos vizinhos; a diferença de caminho é 2 dsen $\theta$.

Figura II-6 - Modelo de von Laue, ilustrando a diferença de caminho para os raios espalhados por dois pontos separados por uma distância d.

Figura 117 - Esfera de Ewald no espaço recíproco bidimensional; $\vec{k}$ é o vetor de onda incidente, $\vec{k} \cdot e^{\prime} 0$ vetor difratado e $\vec{K}$ é o vetor da rede recíproca que satisfaz a relação (II-14). 48

Figura II-8 - a) Espaço recíproco de uma rede de Bravais bidimensional, mostrando as soluções da equação de von Laue (visto de lado); os bastões passando por cada ponto da rede; a 
interseção deste bastões com a esfera de Ewald constitui o padrão de difração sobre a tela fluorescente; b) mesmo fenômeno, mas visto de cima; por semelhança de triângulos podemos determinar diretamente o parâmetro de rede na tela.

Figura II-9 - (a)transmissão, reflexão e difração em superfícies rugosas; (b)reflexão e difração em uma superfície atomicamente lisa

Figura II-10 - Padrão de difração observado na tela fluorescente quando (a)a amostra é rugosa, e (b)quando é lisa. 50

Figura II-11 - Projeção no plano (110) de uma superfície de GaAs (001) reconstruída e terminada com ânions. Em (a) a reconstrução é realizada por dimerização. Em (b) há criação de vacâncias na camada superficial. As ligações pendentes dos ânions estão completamente preenchidas (em preto) e as dos cátions vazias (em branco) ${ }^{56}$ 52

Figura II-12 - Visão esquemática superior de uma superfície reconstruída terminada com ânions, exibindo uma estrutura $2 \times N$ com $D$ ânions diméricos na camada superior e $4 \times(N-D)$ cátions expostos na segunda camada; as ligações pendentes dos ânions (preenchidas) e ligações pendentes vazias dos cátions são também representadas ${ }^{56}$.

Figura II-13 - Outras configurações atômicas satisfazendo a regra de contagem dos elétrons para a reconstrução $2 \times 4^{56}$. A estrutura $\alpha-(2 \times 4)$ possui dois dímeros de arsênio na superfície e dois dímeros de gálio na segunda camada. A estrutura $\beta 2-(2 \times 4)$ possui dos dímeros de arsênio na primeira camada e um terceiro dímero de arsênio na terceira camada. 54

Figura II-14 - Representação da formação das duas primeiras monocamadas completas de GaAs na direção [001] e a correspondente observação através do sistema RHEED; $\theta$ representa o número de monocamadas depositadas; a incidência dos elétrons está na direção [110]; note que as ilhas são mais alongadas na direção [-110].

Figura II-15 - Típica figura mostrando as oscilações RHEED durante o crescimento de GaAs sobre uma amostra (de número 580).

Figura Il-16 - Taxa de deposição (em monocamadas por segundo) em função da temperatura dos fornos de alumínio e gálio ( 2 fornos); os dados foram obtidos por medidas realizadas com o sistema RHEED.

Pigura 1 H-1- Espectro de difração de raios X (Intensida- de[1000 cps] $\times \Delta \omega[\operatorname{arcsec}]$ ) do conjunto de amostras crescido com razão crescente de velocidades de incorporação V/III; (a)\#664, (b)\#663, (c) \#662, (d)\#666, (e)\#667.

Pigura II-2 - Estrutura de um poço quântico de GaAs de $100 \AA$, com barreiras de $\mathrm{Al}_{\mathrm{x}} \mathrm{Ga}_{1-\mathrm{x}} \mathrm{As}$ de 300 A de largura contendo $30 \%$ de alumínio. 
Figura III-3 - Fotoluminescência (PL) das amostras de poços de $\mathrm{GaAs} / \mathrm{Al}_{\mathrm{x}} \mathrm{Ga}_{1-\mathrm{x}} \mathrm{As}$ com variação do tempo de interrupção nas interfaces. A estrutura das amostras é composta de um único poço de $100 \AA$ e barreira de $300 \AA$ com $x=0,3$ 70

Figura IV-1 -- Geometria simples de uma amostra e dos contatos necessários para realizar uma medida de efeito Hall; A, B, C e D representam os contatos elétricos, enquanto que t, l e w são as dimensões da amostra; a corrente elétrica é aplicada entre A e B, e a voltagem de Hall é medida entre C e D 75

Figura IV-2 - Configuração de Van der Pauw para medidas de efeito Hall; A, B, C e D são os contatos elétricos na superficie da amostra. 76

Figura IV-3 - Medidas de efeito Hall (300K) e de fotoluminescencia $(1,4 \mathrm{~K})$ realizadas sobre os conjuntos de amostras de GaAs(100):Si variando-se a temperatura da célula de Si; (a)concentração de elétrons em função de $1 / \mathrm{T}$ ( $\mathrm{T}$ é a temperatura do forno de $\mathrm{Si}$ ); (b)espectros de fotoluminescência das amostras altamente dopadas (segundo conjunto); ambas as medidas mostram o efeito de compensação a alta concentração. 76

Figura IV-4 - Diagrama esquemático das ligações atômicas da superficie do GaAs(311)A projetada no plano (110). 78

Figura IV-5 - Medidas de efeito Hall $(300 \mathrm{~K})$ e de fotoluminescência $(1,4 \mathrm{~K})$ realizadas sobre os conjuntos de amostras de GaAs(311):Si variando-se a temperatura da célula de Si; (a)concentração de buracos em função de $1 / \mathrm{T}$ ( $\mathrm{T}$ é a temperatura do forno de silício); (b)espectros de fotoluminescência das amostras altamente dopadas. 81

Figura IV-6 - Oscilações da intensidade luminosa do feixe especular devido à incorporação de arsênio por 15 camadas de gálio previamente depositadas sobre a superfície de GaAs(100); a célula de gálio ficou aberta até o tempo $t=37 \mathrm{~s}$, provocando uma reconstrução $4 \times 2$ e uma baixa intensidade do feixe especular; no tempo $t=37 \mathrm{~s}$, o obturador da célula de gálio foi fechado e o da célula de arsênio aberto; as oscilações são provocadas pela incorporação de arsênio dentro da camada de gálio puro, formando quinze camadas de GaAs, como demonstra o número de oscilações.

Figura IV-7 - Espectro de fotoluminescência $(1,4 \mathrm{~K})$ da amostra \#920 de GaAs(001):Si mostrando uma banda intensa a $1,42 \mathrm{eV}$, o mesmo valor da energia que para as amostras altamente dopadas da Figura IV-3a onde o efeito de compensação foi relacionado com a formação de um complexo $\mathrm{Si}_{\mathrm{As}}-\mathrm{V}_{\mathrm{Ga}}$; o pico de menor intensidade corresponde a transição da banda de condução para o nível aceitador de carbono $(1,493 \mathrm{eV})$. 85

Figura V-1 - Diagramas de bandas de energia para amostras de poços quânticos múltiplos não 
dopados, com dopagem homogênea e dopagem modulada ${ }^{1 / 6}$; os pontos pretos representam o nível das impurezas doadoras que são presentes unicamente na barreira no caso da dopagem modulada; o gás de elétrons se encontra no material de menor gap que forma o poço.

Figura V-2 - (a)esquema das estruturas do tipo HEMT crescidas em nosso sistema; (b)diagrama de bandas de energia próximo à interface $\mathrm{Al}_{\mathrm{X}} \mathrm{Ga}_{1-\mathrm{X}} \mathrm{As} / \mathrm{GaAs}$; neste tipo de estrutura, o gás de elétrons é bidimensional e confinado num poço de potencial estreito criado na interface entre os dois materiais.

Figura V-3 - Diagrama esquemático dos espelhos de Bragg crescidos para $\lambda=810 \mathrm{~nm}$; a superrede limita a migração dos átomos de cromo contidos no substrato; $\mathrm{L}_{1}$ e $\mathrm{L}_{2}$ indicam a largura da camada para cada material.

Figura V-4 - Medidas de refletividade dos espelhos de Bragg; são apresentados os gráficos normalizados da refletividade das amostras (a)do primeiro conjunto, crescido para obter-se um máximo em $\lambda=810 \mathrm{~nm}$ e (b)do segundo conjunto $\operatorname{com} \lambda=980 \mathrm{~nm}$.

Figura V-5 - Espectro de raios $\mathrm{X}$ das amostras do primeiro conjunto obtido com a configuração de cristal duplo; na ordenada temos o logaritmo do número de contagem I e na abcissa o ângulo de espalhamento, em graus; a curva vermelha representa os dados experimentais e a preta a simulação teórica com os dados nominais do crescimento. 98 


\section{ÍNDICE DE TABELAS}

Tabela IIl-1 - Parâmetros usados para o crescimento das amostras do primeiro conjunto (1 $\mu$ m de espessura).

Tabela III-2 - Tempo de interrupção de crescimento realizado nas duas interfaces das amostras do segundo conjunto.

Tabela IV-1 - Dados e resultados do crescimento das amostras do primeiro conjunto, usado para a calibração da taxa de evaporação do forno de silício; uma camada de GaAs dopada com silicio, de $1 \mu \mathrm{m}$ de espessura, foi depositada sobre substratos de GaAs possuindo uma superficie paralela ao plano (001) - números ímpares - e (311)A - números pares. 80

Tabela IV-2 - Dados do crescimento das amostras altamente dopadas com silício, formando o segundo conjunto, crescidas sobre substratos de GaAs; os números ímpares correspondem aos substratos (001), e os pares aos (311)A.

Tabela V-1 - Parâmetros de crescimento e resultados experimentais das estruturas HEMTs de $\mathrm{GaAs} / \mathrm{Al}_{\mathrm{x}} \mathrm{Ga}_{1-\mathrm{x}} \mathrm{As}$

Tabela V-2 - Dados do crescimento dos espelhos de Bragg para $\lambda=810 \mathrm{~nm}$; $L$ é a largura das camadas em $\AA$. 95

Tabela V-3 - Dados do crescimento dos espelhos de Bragg para $\lambda=980 \mathrm{~nm}$; $L$ indica a largura das camadas em $\AA$; a amostra $\# 822$ foi crescida usando-se o método de pseudo-liga. 


\section{INTRODUÇÃO}

No final da década de sessenta, ocorreu uma revolução tecnológica na indústria da microeletrônica e optoeletrônica devido à aparição de fibras ópticas que podiam ser utilizadas para a transmissão de informações a longa distância. Precisou-se então produzir novos dispositivos operando em mais altas freqüências ${ }^{1,2}$ (transistores de alta mobilidade) ou emitindo uma radiação próxima ao espectro visível ${ }^{3,4}$ (diodo luminoso, laser). Houve também uma grande preocupação em diminuir o tamanho dos dispositivos para que o tempo de transferência pelo componente seja minimizado. Portanto, técnicas de produção de filmes finos precisavam ser empregadas para que a escala vertical do dispositivo pudesse ser reduzida significativamente.

Junto com este interesse tecnológico, a curiosidade científica relacionada com as propriedades peculiares de camadas finas, apresentando efeitos quânticos pronunciados 5 , impulsionou o surgimento de novos métodos de crescimento de amostras. No final da década, técnicas tais como LPE (liquid phase epitaxy), CVD (chemical vapor deposition), sputtering e a evaporação térmica já eram conhecidas. Todavia, nenhuma delas possibilitava o controle da deposição de material a nível atômico.

Em $1970^{6}$, Cho propôs uma nova técnica de evaporação, onde, graças à presença de ultra alto vácuo na câmara de deposição, feixes de materiais de alta pureza podiam ser incididos sobre um substrato aquecido, produzindo um filme fino de mesma estrutura cristalina que o substrato. Devido às baixas taxas de crescimento obtidas e ao controle extremamente preciso dos feixes, as camadas podiam ser depositadas com precisão atômica. A possibilidade de obtenção de perfis de dopagem abruptos ${ }^{7}$, a disponibilidade de ligas ${ }^{8}$ possuindo um gap diferente e parâmetros de rede compativeis, assim como a existência de uma instrumentação sofisticada de caracterização ${ }^{9}$ in situ fizeram da técnica de epitaxia por feixe molecular (MBE, molecular beam epitaxy) uma das mais populares e mais poderosas do mercado.

Em 1991, nosso grupo de pesquisa (o Laboratório de Novos Materiais Semicondutores, LNMS) adquiriu um sistema de crescimento epitaxial por feixe molecular para fornecer aos pesquisadores brasileiros amostras de heteroestruturas semicondutoras de compostos III-V de alta qualidade. Entre os compostos semicondutores III-V mais estudados atualmente, o arseneto de gálio (GaAs) e seus derivados (AlGaAs, InGaAs, InAs, AlAs), que podem agora ser crescidos em nosso laboratório, destacam-se pelas suas propriedades ópticas e eletrônicas muito interessantes tanto do ponto de vista da pesquisa básica quanto de suas aplicações na indústria da microeletrônica, da optoeletrônica e das telecomunicações. 
Até o final de 1996, a maior parte das amostras crescidas por nosso sistema MBE, tanto para nosso grupo quanto para outros grupos de pesquisa, era destinada à pesquisa básica. Tratavam-se principalmente de estruturas com poços quânticos, super-redes e dopagem planar usando ligas binárias ou ternárias. Como um sistema MBE é a ferramenta ideal para produzir camadas semicondutoras de alta pureza e qualidade cristalina, iniciamos em 1996 uma nova linha de pesquisa baseada no estudo de camadas epitaxiais dopadas, do tipo n e p, para aplicação na área da microeletrônica e optoeletrônica.

Este trabalho representa o primeiro passo de uma longa caminhada até a fabricação de um dispositivo possuindo boas propriedades ópticas ou eletrônicas.

O primeiro capítulo foi dedicado exclusivamente à descrição do sistema MBE em geral e de alguns de seus instrumentos ou equipamentos característicos. Ele representa uma parte importante do trabalho no sentido que o crescimento de amostras de boa qualidade só é possível se o crescedor dominar perfeitamente cada parâmetro do sistema. Ele foi escrito de tal maneira que possa servir, no futuro, como ponto de partida e manual de referência para os próximos alunos que precisarão operar o sistema MBE.

As características e condições do crescimento epitaxial por feixe molecular foram abordadas no segundo capítulo. O sistema RHEED (reflection high-energy electron difraction) foi descrito nesta parte, já que ele é o instrumento de caracterização in situ mais versátil e poderoso do sistema MBE e que ele pode ser utilizado tanto para fornecer parâmetros básicos do crescimento quanto para investigar fenômenos superficiais a nível atômico.

Para obterem-se camadas de natureza diferente numa mesma amostra, o crescimento de cada uma precisa ser otimizado para que as outras não sejam prejudicadas. O terceiro capítulo aborda o problema da otimização do crescimento de camadas espessas de GaAs e AlGaAs. Foram estudadas algumas condições para o crescimento e otimização de heteroestruturas formadas por esses dois materiais.

A dopagem de uma amostra é indispensável quando se deseja crescer camadas epitaxiais destinadas à fabricação de dispositivos eletrônicos. Estudamos, no capítulo quatro, os dois tipos de dopagem, $n$ e $p$, e investigamos mais particularmente a produção de camadas do tipo $p$ por novas técnicas, já que o elemento berílio, geralmente utilizado neste caso, não estava disponivel em nosso sistema.

No último capítulo, amostras específicas foram crescidas e representaram a primeira tentativa de aplicação de camadas epitaxiais (realizadas em nosso grupo) em dispositivos eletrônicos e optoeletrônicos. Camadas com alta mobilidade de portadores foram conseguidas, 
assim como espelhos de alta refletividade que são muito úteis na fabricação de lasers semicondutores a cavidade vertical. 


\section{I - O sistema de crescimento epitaxial por feixe molecular}

\section{I.1 - Descrição geral do sistema}

O sistema de epitaxia por feixe molecular do Laboratório de Novos Materiais Semicondutores do Instituto de Física da USP (LNMS/IFUSP) é composto por três câmaras de ultra alto vácuo (UHV, ultra-high vacuum) construidas em aço inoxidável e isoladas entre si por válvulas do tipo gaveta. Essas câmaras são chamadas de câmara de entrada/saída, câmara intermediária e câmara de crescimento (Figura l-1).

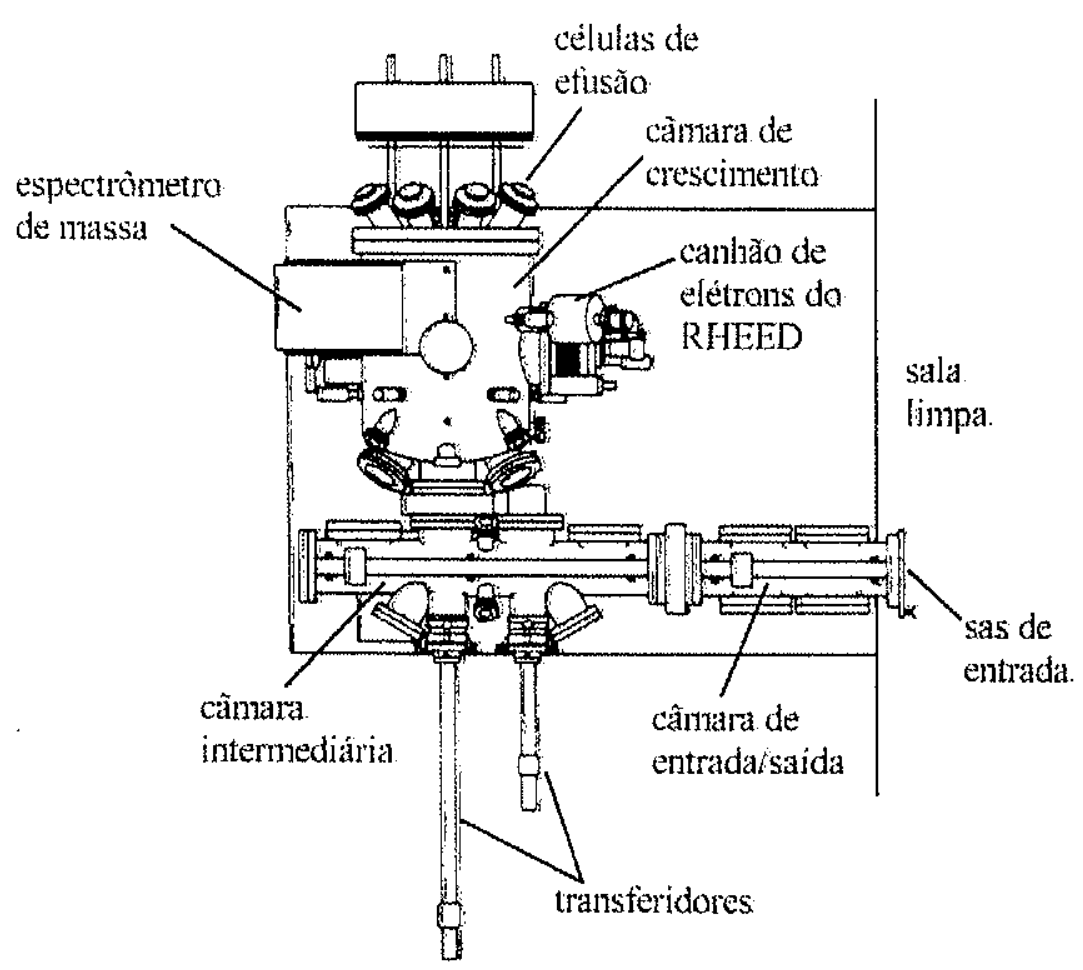

Figura I-I - Esquema do sistema MBE do LNMS-IFUSP com algumas de suas caracteristicas ${ }^{10}$; as câmaras são construidas em aço inoxidável e isoladas entre si por válvulas do tipo gaveta; o sas de entrada da câmara de entrada/saida abre dentro de uma sala limpa.

Cada câmara possui um sistema de bombeamento próprio, constituído por uma bomba iônica e uma bomba de sublimação de titânio (exceto a câmara de entrada/saída que possui unicamente uma bomba iônica). Estas três câmaras são também interconectadas a um sistema comum de pré-vácuo, usado quando o sistema MBE é levado à pressão ambiente para manutenção, constituído por uma bomba Ventury, funcionando com ar comprimido, e duas 
bombas de adsorção, resfriadas por nitrogênio liquido.

As câmaras de entrada/saida e intermediária são percorridas, em sua parte inferior, por um trilho sobre o qual pode-se deslocar um "carrinho" contendo os substratos prontos para o crescimento. Dessa maneira, as amostras introduzidas na câmara de entrada/saida podem ser transferidas para a câmara intermediária (uma vez que a válvula gaveta, separando as duas câmaras, for aberta), e posteriormente para a câmara de crescimento.

Esse carrinho (Figura l-2), com capacidade para 16 amostras, é movido sobre o trilho, usando-se um ímã permanente externo que interage com os imãs permanentes fixados na parte superior de sua estrutura. Desta maneira, a amostra desejada pode ser posicionada frente aos transferidores da câmara intermediária usados para levá-la em locais específicos das câmaras (no forno de desgaseificação da câmara intermediária e no forno da câmara de crescimento). Todas

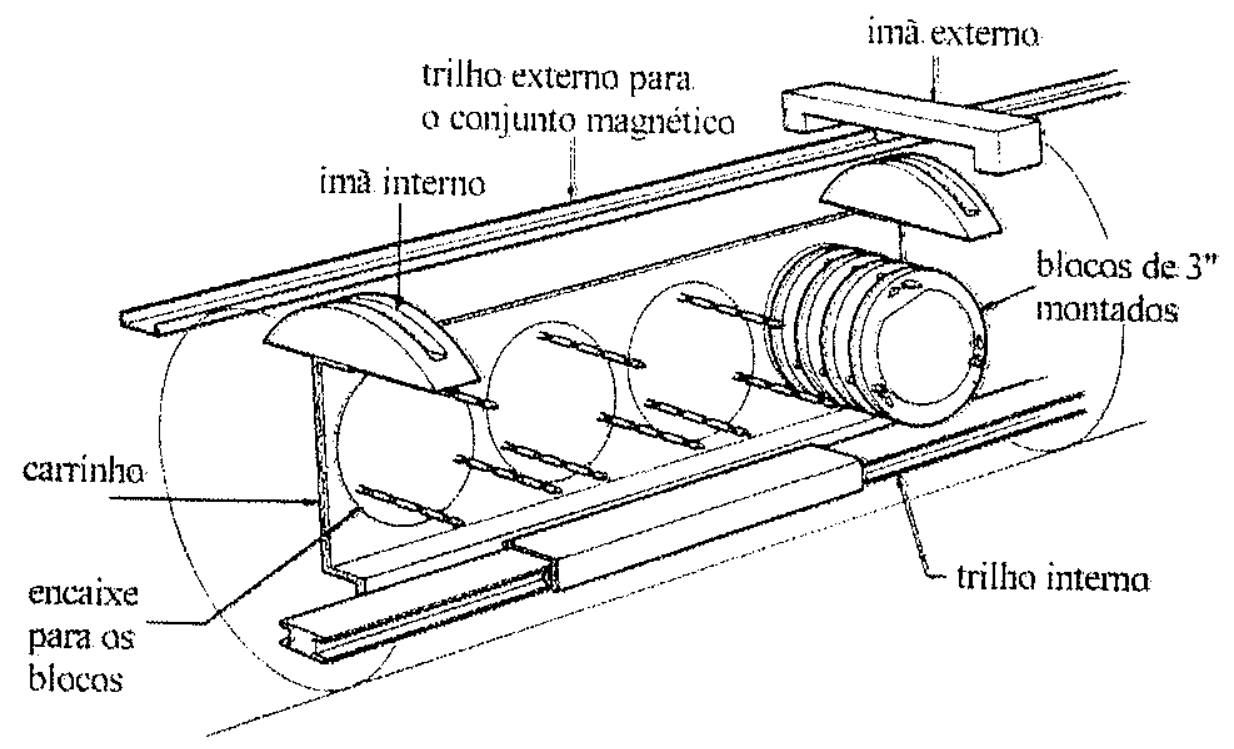

Figura I-2 - Carrinho de amostras ("trolley") usado em nosso sistema, mostrado sobre o trilho da câmara intermediária; o carrinho possui capacidade para 16 blocos de Mo de 3 " cada e se movimenta através de imấs (as
meia luas na parte superior do carrinho) ${ }^{10}$.

as câmaras possuem várias janelas de observação, estrategicamente dispostas, para o manuseio dos transferidores e a observação dos substratos. Vários instrumentos, tais como medidores de pressão do tipo Bayard-Alpert, um espectrômetro de massa quadrupolar, um pirômetro e um sistema RHEED, são utilizados in situ para caracterizar a qualidade do vácuo ou as condições de crescimento.

A câmara de entrada/saída (à direita na Figura I-3) é a menor das três câmaras. O sas de entrada é o único acesso ao interior do sistema MBE e encontra-se dentro de uma sala limpa 
para minimizar a contaminação do ambiente interno. Esta câmara possui uma bomba iônica com vazão de 60 1/s, um medidor de pressão do tipo Bayard-Alpert e duas resistências elétricas de 40 cm de comprimento, situadas simetricamente de cada lado da entrada, para a desgaseificação do carrinho e suas amostras. A desgaseificação é realizada a $200^{\circ} \mathrm{C}$ por uma hora (no mínimo), sempre que novas amostras são preparadas e introduzidas no sistema de crescimento. Esse tratamento térmico é necessário para minimizar a contaminação do resto do sistema MBE pelos produtos usados durante a limpeza dos substratos ou pelo carrinho que pode ter sido contaminado durante o tempo em que permaneceu na sala limpa. Deste modo, a maior parte destas substâncias será desadsorvida na câmara de entrada, o que manterá a integridade das outras. Esta câmara é circundada por uma camisa de aço inoxidável na qual circula um fluxo de água fria deionizada que isola termicamente as paredes externas e minimiza a desadsorção de gases presentes sobre as paredes internas durante a desgaseificação. Essa água faz parte de um circuito fechado, equipado com um trocador de calor e dedicado exclusivamente ao sistema MBE. Ele é usado para resfriar várias partes das câmaras que são suscetíveis de aquecimento, prejudicando suas propriedades mecânicas e a qualidade do vácuo. Em condições normais, a pressão na câmara de entrada/saída é tipicamente da ordem de $2-4 \times 10^{-8}$ Torr, visto que seu interior está em contato freqüente com o ar atmosférico.

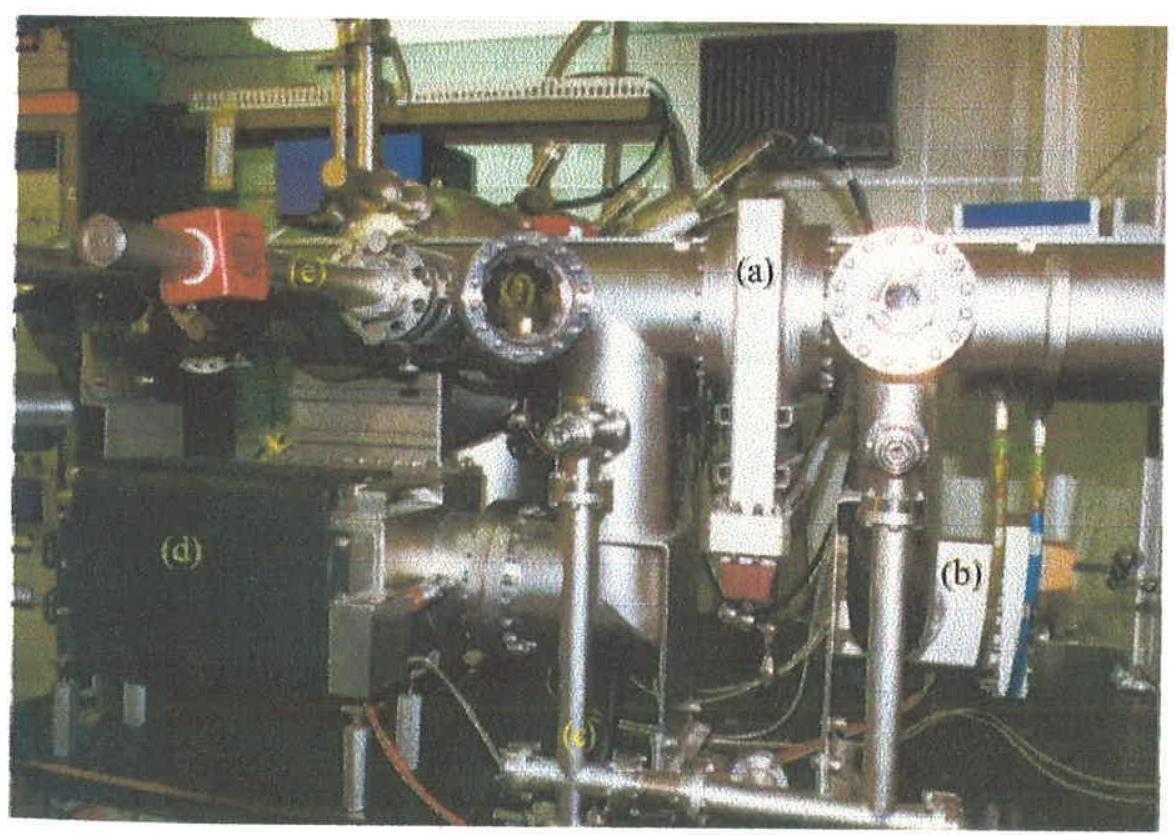

Figura I-3 - Detalhes das câmaras intermediária (lado esquerdo da figura, com a câmara de crescimento ao fundo) e de entrada/saida (à direita); a) válvula gaveta que separa as duas câmaras; b) válvula gaveta entre a câmara de entrada/saida e sua bomba iônica; c) conexões com as para bombas Ventury e de adsorção; d)bomba iônica da câmara intermediária; e) um dos transferidores; fjjanela de observação.

Após a desgaseificação na câmara de entrada/saída, as amostras são transferidas para a 
câmara intermediária onde receberão individualmente um tratamento térmico a mais alta temperatura e aguardarão o crescimento. Essa câmara, de mesmo formato que a anterior, mas ligeiramente maior, possui uma bomba iônica com vazão de 220 1/s, uma bomba de sublimação de titânio (com 3 filamentos), um medidor de pressão do tipo Bayard-Alpert, um forno para a desgaseificação final das amostras e dois transferidores para o manuseio dos substratos no interior das câmaras. Desta vez, o processo de desgaseificação é realizado a $350^{\circ} \mathrm{C}$ por 30 minutos. A temperatura não pode ser muito mais elevada, pois ocorre então a evaporação do arsênio, o que danifica a estrutura cristalina do substrato (a superfície fica rica em gálio) e inviabiliza a obtenção de camadas epitaxiais de boa qualidade. É importante que as amostras esperem pelo crescimento nesta câmara, em vez da câmara de entrada/saída, pois o ambiente é muito mais limpo e a pressão está normalmente na faixa de $1-2 \times 10^{-10}$ Torr, minimizando qualquer contaminação.

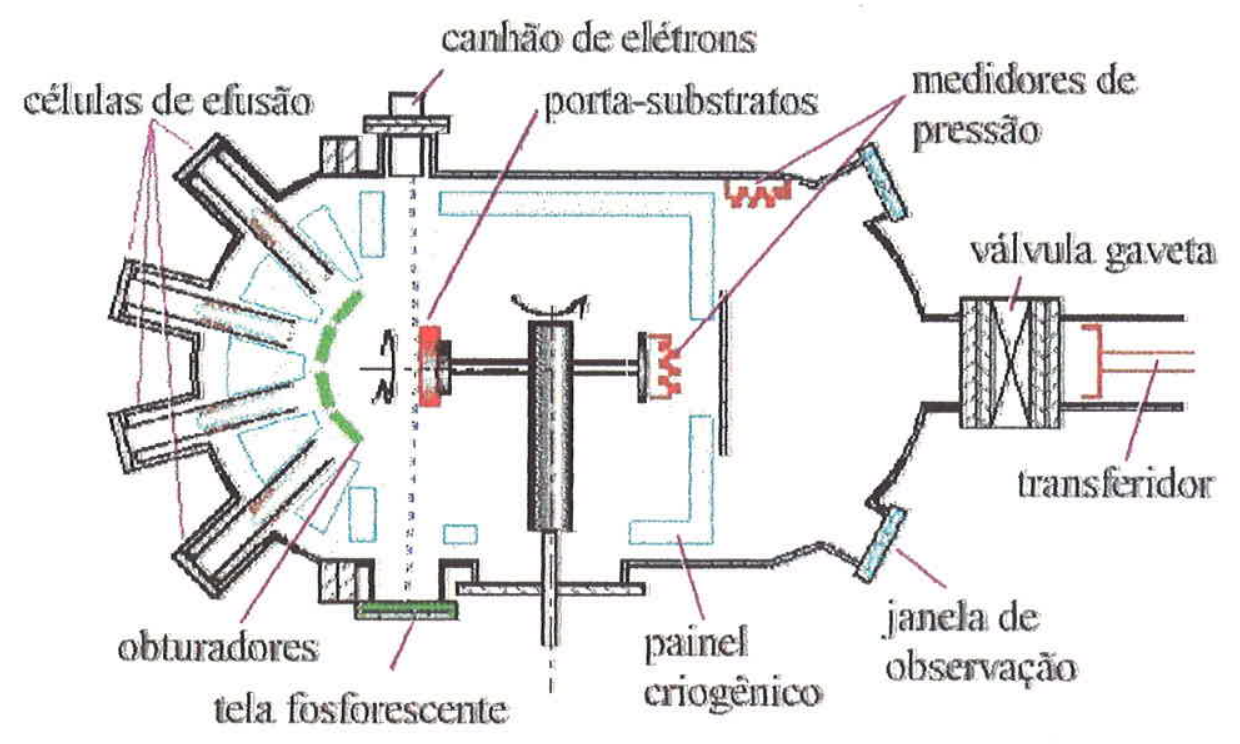

Figura I-4 - Interior da câmara de crescimento de nosso sistema MBE; uma válvula gaveta separa as câmaras de crescimento e intermediária; o painel criogênico cerca a região dos fluxos; o medidor de pressão fora dessa região mede a pressão do gás residual na câmara, enquanto que o outro (a $180^{\circ}$ do porta-amostras) é usado como medidor de fluxo, quando estiver na posição do substrato.

A câmara de crescimento é a maior de todas (ela representa $80 \%$ do volume total de nosso sistema MBE) e possui um formato específico (dois cilindros, de grande diâmetro, colocados um acima do outro, a 90 graus) determinado pela disposição física de todos os instrumentos necessários ao crescimento e à caracterização in situ das camadas epitaxiais. $\mathrm{O}$ conjunto de vácuo é composto de uma bomba iônica de 400 1/s e uma bomba de sublimação utilizando uma bola de titânio aquecida internamente por uma resistência de tungstênio. A câmara é circundada por uma painel criogênico, dentro do qual circula nitrogênio líquido que 
atua como uma bomba criogênica. A câmara possui oito células de efusão, sendo que duas são carregadas com arsênio (As), duas outras com gálio (Ga), uma com alumínio ( $\mathrm{Al}$ ) e uma outra com índio (In). As duas últimas são destinadas aos elementos usados como dopantes, o silício e o berílio, que são geralmente utilizadas para produzir camadas do tipo $\mathrm{n}$ e p respectivamente.

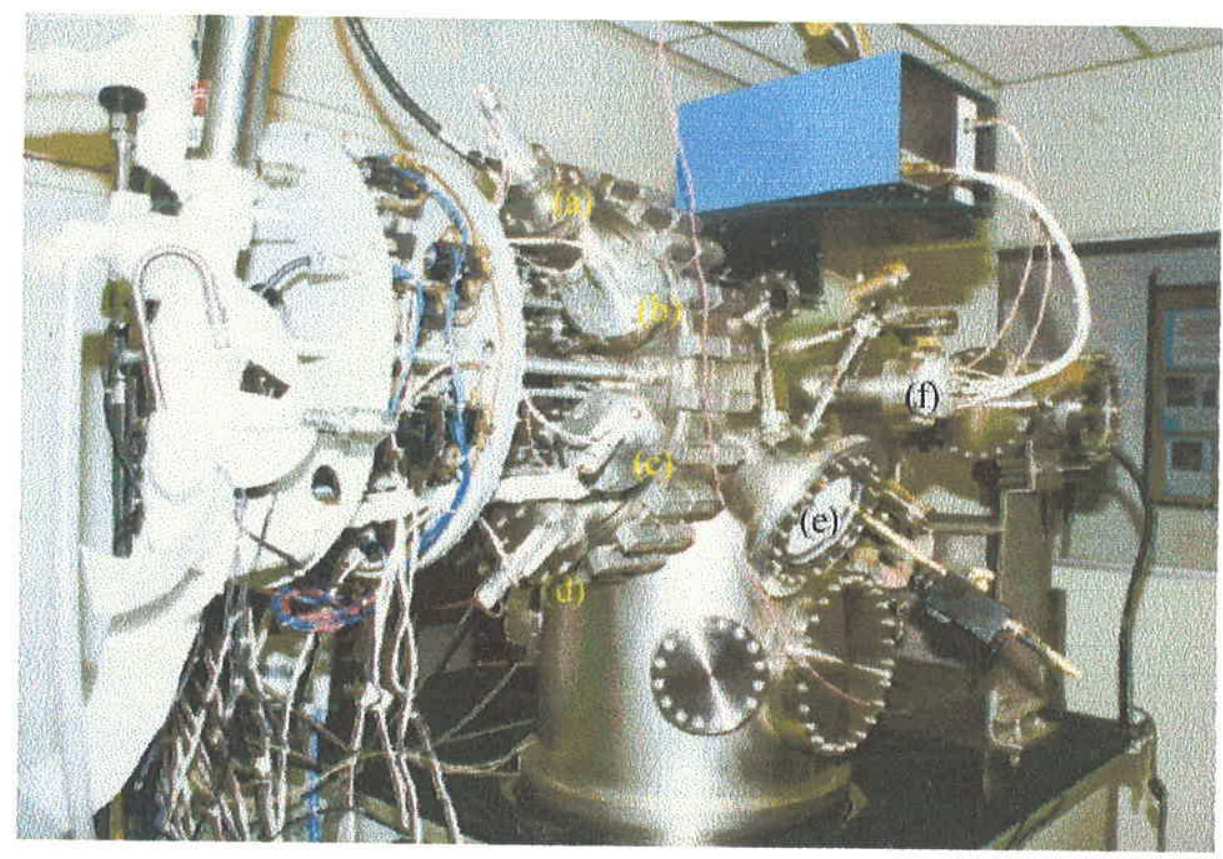

Figura I-5 - Foto da câmara de crescimento, com vista das células de efusão de a)Si, b)As, c)Al e d) Ga; continuando em sentido horário, temos as outras células de Ga, In, As e Be, não mostradas na foto; e)tela fluorescente do sistema RHEED, f)espectrômetro de massa.

As células são dispostas circularmente e simetricamente sobre a flange principal (traseira) de 18 polegadas de diâmetro, e inclinadas de um mesmo ângulo para apontarem na direção do porta-amostras localizado no centro da câmara. No centro desta flange existe uma janela de quartzo usada para realizar a medida de temperatura da amostra com o pirômetro. Cada célula possui um obturador pneumático (acionado com ar comprimido e controlado por computador) permitindo uma interrupção precisa dos feixes (em torno de $0,1 \mathrm{~s}$ ) de moléculas ou átomos oriundos das células e possibilitando o crescimento de estruturas de composição ou natureza diferente com interfaces abruptas.

A temperatura das células é controlada por termopares individuais, cujo sinal é processado e transmitido a uma fonte de corrente que fornece a potência elétrica necessária para aquecer a célula correspondente. O circuito de retroação interno é baseado no sistema $\mathrm{P}$, I e $\mathrm{D}^{11,12}$ (iniciais das palavras Proportional, Integrative e Derivative) que, uma vez bem calibrado, possibilita a subida ou descida rápida e eficiente (com um mínimo de oscilações) da temperatura, ajustando-a ao valor pré-determinado pelo usuário e mantendo-a estabilizada em 
mais ou menos $0,1^{\circ} \mathrm{C}^{13}$. Esse mesmo tipo de fonte é usada para realizar a desgaseificação das amostras na câmara intermediária ou para aquecer as amostras durante o crescimento.

Para auxiliar o crescedor, existem vários instrumentos dentro da câmara que fornecem dados sobre a pressão total (medidor de Bayard-Alpert), a composição do gás residual (espectrômetro de massa) e as condições de crescimento (sistema RHEED). Um programa computacional foi escrito em linguagem $C^{14}$ para controlar os parâmetros importantes do crescimento, i.e. a temperatura da amostra e das células durante o crescimento, assim como a abertura e o fechamento dos obturadores. Dessa maneira, estruturas periódicas com dopagem e interfaces abruptas podem ser elaboradas com alta precisão.

No caso de uma queda de energia repentina, o computador e os fornos são ligados a um sistema no-break de 10kVA possuindo uma autonomia de 10 minutos, tempo suficiente para o desligamento correto das células de efusão e o salvamento dos dados armazenados no computador.

Cada amostra é colada sobre um bloco de molibdênio (Mo) que é posicionado contra uma placa difusora em nitreto de boro (o forno da câmara de crescimento mostrado na Figura I6) que é aquecida por filamentos de tungstênio. A amostra pode ser girada continuamente acima do forno (mesmo durante o crescimento), para homogeneizar a deposição dos materiais, graças a um sistema motorizado de rolamentos. Como ela é introduzida na câmara de crescimento através do transferidor principal da câmara intermediária, o forno (que está frente às células durante o crescimento) precisa ser girado de 180 graus para permitir a transferência. Para isto, o conjunto inteiro do forno é solidário de um mecanismo possibilitando esta rotação dentro da câmara quando for necessária (ver Figura I-4). Atrás do forno, existe um medidor de fluxo que é posicionado frente às células toda vez que o forno for colocado em posição de transferência. Neste caso, o medidor possibilita uma estimativa do fluxo de partículas emanante de cada célula quando seu obturador estiver aberto. Esta medida é muito importante, pois fornece a quantidade de material que estará incidindo sobre a amostra quando ela estiver na posição de crescimento (ja que o medidor de fluxo está ocupando exatamente a mesma posição que a amostra ocupará) e determina as principais condições de crescimento (razão de fluxo, taxa de crescimento, reconstrução da superfície, etc.).

Um segundo medidor de pressão do tipo Bayard-Alpert, situado fora da região dos fluxos e do painel criogênico, mede a pressão do gás residual na câmara (e não na região de erescimento que é circundada pelo painel criogênico - ver Figura I-4).

A agua deionizada do circuito fechado de refrigeração é usada para a refrigeração de 
algumas partes mecânicas do forno. Ela é necessária para que não haja aquecimento acentuado das engrenagens e dos rolamentos do motor devido à temperatura do substrato durante o crescimento (em torno de $600^{\circ} \mathrm{C}$ ). A mesma água serve também para resfriar o painel da bomba de sublimação de titânio localizado na parte inferior da câmara (ver Figura I-10b).

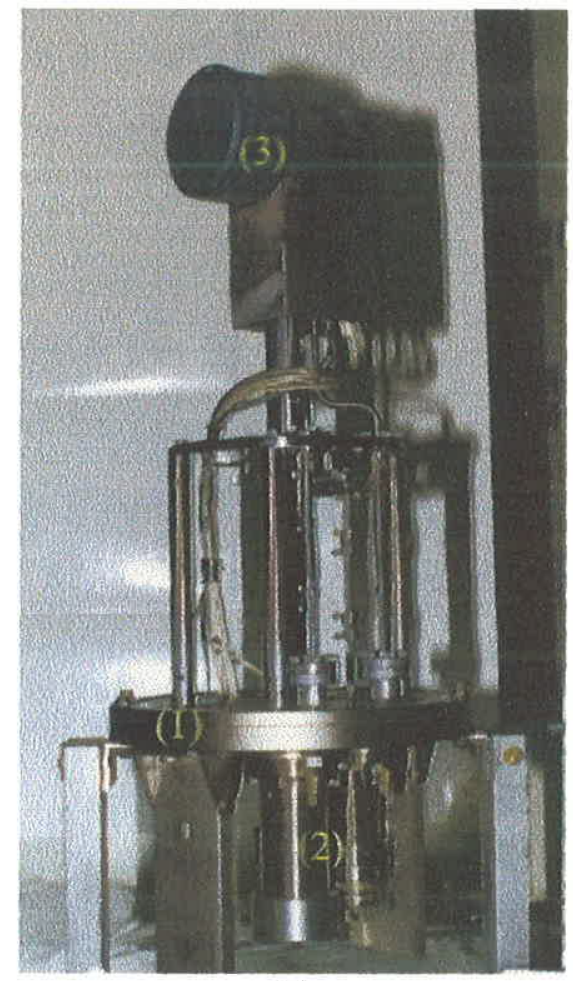

(a)

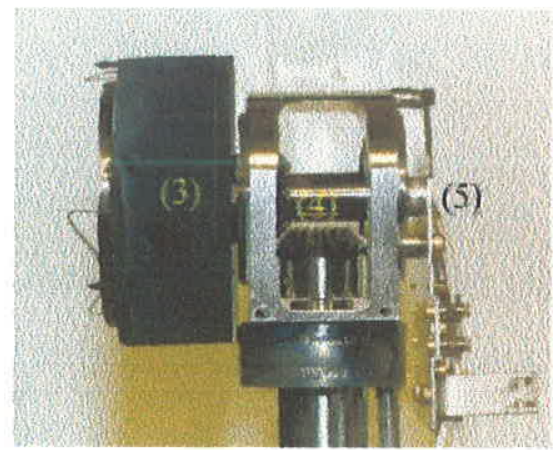

(b)

Figura I-6 - Fotos do conjunto sustentando o forno da amostra; a)vista da peça por inteiro, onde pode-se ver a flange (1), os eixos de rotação (2) e o porta-amostras (3); b) detalhes da parte superior, mostrando a parte externa do forno (3), as engrenagens para a rotação (4) e a posição do medidor de fluxo (retirado no momento da foto) (5).

A câmara de crescimento possui ainda dois equipamentos de caracterização que possibilitam a determinação das condições de crescimento. $\mathrm{O}$ espectrômetro de massa quadrupolar fornece uma leitura da abundância dos elementos da tabela periódica dentro do sistema, possibilitando uma análise quantitativa da pureza do gás residual antes, durante ou depois do crescimento. O sistema RHEED é constituído por um canhão de elétrons, cujo feixe incide sobre a amostra com um ângulo rasante de alguns graus (ver Figura I-4). O padrão de difração é recolhido por uma tela fluorescente e fornece vários parâmetros importantes relacionados com o arranjo cristalino da superfície ou as taxas de crescimento das ligas.

\section{I.2 - Vácuo}

O crescimento epitaxial por feixe molecular é, essencialmente, uma técnica de evaporação no vácuo. Graças aos enormes progressos realizados nas duas últimas décadas em ciência do vácuo, pressões cada vez menores puderam ser alcançadas, o que possibilitou o uso de sistemas de caracterização in situ e a produção de amostras de maior pureza. 
Dependendo da pressão $p$ presente na câmara, o vácuo realizado é definido como ultra alto vácuo quando $p \leq 10^{-7} \operatorname{mbar}\left(1 \mathrm{~atm}=10^{5} \mathrm{~Pa}=760 \mathrm{Torr}=1000 \mathrm{mbar}\right)$, como alto vácuo quando $10^{-7}$ mbar $\leq p \leq 10^{-3}$ mbar, como vácuo médio quando $10^{-3}$ mbar $\leq p \leq 10^{\circ} \mathrm{mbar}$ e como vácuo baixo (ou grosseiro) quando $10^{\circ} \mathrm{mbar} \leq p \leq 10^{3} \mathrm{mbar}$. Portanto, todas as câmaras de um sistema MBE operam geralmente em regime de ultra alto vácuo, pois a pressão do gás residual no ambiente está geralmente na faixa de $10^{-10}$ Torr (e $10^{-8}$ Torr na câmara de entrada/saída).

No vácuo, a atividade química do gás atmosférico, tal como a oxidação de metais, é grandemente reduzida, tornando possivel o armazenamento de materiais altamente reativos. No ultra alto vácuo, superfícies podem ser mantidas limpas por várias horas, sem a deposição sequer de uma monocamada de contaminantes. O tempo necessário para cobrir uma superfície por uma camada atômica de impurezas é da ordem de 28 horas numa pressão de $10^{-10} \operatorname{Torr}^{15}$ (enquanto que é de 5 minutos a $10^{-5}$ Torr). Portanto, nessas excelentes condições de vácuo, pode-se pesquisar propriedades sobre superfícies atomicamente limpas. Devido à qualidade do vácuo, o aumento do livre caminho médio possibilita o uso de partículas carregadas, tais como elétrons ou íons, cujos caminhos, na ausência de colisões, podem ser controlados por campos elétricos ou magnéticos.

A necessidade de empregar sistemas de bombeamento possibilitando o acesso ao regime de ultra alto vácuo num sistema MBE é ditada pelas baixíssimas taxas de crescimento (em torno de $1 \mu \mathrm{m} / \mathrm{h}$, o que equivale a uma monocamada de GaAs por segundo) e a exigência de níveis de impurezas muito baixos nas camadas epitaxiais produzidas ${ }^{16}$. Nestes valores de pressão o gás residual contém predominantemente moléculas de hidrogênio $\left(\mathrm{H}_{2}\right)$, água $\left(\mathrm{H}_{2} \mathrm{O}\right)$, oxigênio $\left(\mathrm{O}_{2}\right)$, mono e dióxido de carbono $\left(\mathrm{CO}\right.$ e $\left.\mathrm{CO}_{2}\right)$ assim como gases inertes $(\mathrm{Ne}, \mathrm{Ar})$ que são dificilmente bombeados e complexos de carbono* provenientes dos solventes (acetona, metanol) usados na limpeza do sistema.

Um esforço considerável é geralmente realizado para assegurar que os níveis de $\mathrm{H}_{2} \mathrm{O}, \mathrm{O}_{2}$, $\mathrm{CO}$ e $\mathrm{CO}_{2}$ sejam significativamente mais baixos do que os apresentados em sistemas UHV convencionais, pois poderiam reagir com o alumínio presente na câmara e piorar a qualidade das amostras. Além disso, como o carbono é incorporado nas camadas epitaxiais dos elementos III$\checkmark$, criando um nível aceitador raso ( $26 \mathrm{meV}$ acima da banda de valência), sua concentração deve ser minimizada para que camadas intrínsecas ou do tipo $n$ possam ser obtidas sem problemas.

\footnotetext{
Compostos contendo carbono, geralmente hidrocarbonos.
} 


\subsection{1 - Bombas de vácuo}

As bombas de vácuo podem ser divididas em duas classes: bombas de pré-vácuo e bombas de alto vácuo. As primeiras são bombas que começam a operar à pressão atmosférica e conseguem produzir um vácuo de até $10^{-3}$ Torr. Exemplos destas bombas, são as bombas rotativas e as bombas de adsorção.

As bombas de alto-vácuo são aquelas que só podem começar a operar às pressões mais baixas que a atmosférica e atingem pressões de até $10^{-11}$ Torr. Exemplos dessas são as bombas de difusão, bombas iônicas, bombas criogênicas e bombas turbomoleculares. Estas bombas trabalham em conjunto com bombas de pré-vácuo que reduzem a pressão a niveis baixos o suficiente para iniciar a operação das bombas de alto-vácuo.

Em nosso sistema, usamos quatro tipos de bombas. Uma bomba Ventury (a ar comprimido) e duas bombas de adsorção são responsáveis pelo pré-vácuo das câmaras. Bombas iônicas levam o sistema até o regime de UHV, e bombas de sublimação de titânio são usadas como auxiliares para diminuir a presença de alguns tipos de gases reativos. Todas estas bombas são do tipo seco, no sentido que não usam nenhum tipo de lubrificante (óleo, graxa) que possa contaminar o ambiente das câmaras.

\subsubsection{1 - Bomba Ventury (ar comprimido)}

As três câmaras do sistema MBE possuem ligações diretas com as bombas de pré-vácuo para a produção do vácuo baixo. Elas são usadas para iniciar o bombeamento iônico e recuperar a integridade do vácuo toda vez que as câmaras forem expostas ao ar para manutenção ou troca de amostras no carrinho.

A primeira bomba a ser usada, a partir da pressão atmosférica, é a bomba Ventury. Tratase de um sistema de pequena dimensão (um cilindro de $20 \mathrm{~mm} \times 150 \mathrm{~mm}$ ) com o qual a pressão pode ser baixada até algumas centenas de Torr. Um gás em alta pressão (em nosso caso, trata-se de ar comprimido a 80 PSI - 1 PSI (Pounds per Square Inch) $=51,7$ Torr) é injetado numa extremidade e sai pela outra. No meio da bomba, existe uma válvula possibilitando a entrada do gás a ser bombeado. Quando esta estiver aberta, o gás é misturado ao ar comprimido sob alta pressão que the transfere uma parte de seu momento cinético e o leva para a saída da bomba. Trata-se do mesmo princípio empregado nas bombas difusoras, sendo que nesse caso, o ar comprimido é substituído por um óleo que é evaporado e cujas moléculas são injetadas na região de bombeamento com alto momento cinético e levam o gás presente na câmara até a saída da 
bomba por transferência de momento. A grande diferença entre estes dois sistemas, além da diferença de pressão final e de funcionamento (uma bomba difusora precisa de um pré-vácuo e pode alcançar pressões da ordem de $10^{-8}$ Torr), é que a bomba Ventury não precisa de lubrificante suscetivel de contaminar o ambiente bombeado.

\section{I.2.1.2 - Bomba de adsorção}

O fenômeno de adsorção é definido como a interação (fraca ou forte) das moléculas de um gás com uma superfície sólida. Dependendo da intensidade da interação, faz-se a diferença entre a adsorção física (physisorption), onde as moléculas são ligadas por forças do tipo van der Waals, e a adsorção química (chemisorption), onde existe uma verdadeira ligação química, envolvendo energias de alguns $\mathrm{eV}$ (dez vezes maior que no caso da adsorção física). $\mathrm{O}$ mecanismo de adsorção física pode levar (dependendo do material usado) também ao fenômeno de absorção (por penetração dentro do sólido), já que as moléculas adsorvidas possuem uma certa mobilidade. Como as moléculas de gás são removidas do ambiente, existe portanto um real efeito de bombeamento devido à interação com a superfície. Todavia, não se trata de uma bomba no sentido comum, já que o gás não é conduzido para a saida da bomba, mas sim armazenado dentro.

Para ser eficiente, uma bomba de adsorção precisa conter um material que possua uma superficie efetiva muito grande para adsorver o maior número possível de moléculas de gás. Usa-se geralmente materiais sintéticos, chamados zeolitas, que são silicatos de alumínio contendo também um outro metal, tal como sódio, cálcio ou lítio. As zeolitas possuem uma estrutura cristalina peculiar que contém um grande número de poros microscópicos que aumentam consideravelmente a superficie efetiva do sólido.

A bomba de adsorção consiste de um recipiente contendo uma grande quantidade de zeolita sob a forma de granulados de alguns milímetros de comprimento. Esses silicatos possuem uma grande quantidade de água, que, quando drenada, libera os poros. Esses possuem um diâmetro de $4 \AA$ a $10 \AA$ (dependendo do método de fabricação) que é comparável com o diâmetro das moléculas dos gases a serem bombeados (o ar é formado por $78 \%$ de nitrogênio e $21 \%$ de oxigênio cujas moléculas são desta ordem de tamanho). Como o fenômeno de adsorção ¿́ mais eficiente à baixa temperatura (temperaturas altas facilitam a desadsorção), a zeolita é geralmente resfriada com nitrogênio líquido. O design da bomba deve oferecer a maior área possível para a adsorção dos gases e, devido à baixa condutividade térmica da zeolita, deve permitir uma refrigeração adequada para todo o material poroso dentro do recipiente. Para isso, 
paletas metálicas distribuem a temperatura mais uniformemente no interior do recipiente. Se grãos, distantes da superfície resfriada com nitrogênio líquido, permanecerem aquecidos, estes agirão como fontes de gás, limitando a pressão final. As bombas baseadas nesse processo tendem a saturar com o tempo e devem ser continuamente reativadas. A reacivação é realizada aquecendo-se a bomba a $200^{\circ} \mathrm{C}$ para provocar a liberação do gás adsorvido por uma válvula de escape.

Em nosso sistema, são usadas duas bombas de adsorção em paralelo, resfriadas por nitrogênio líquido. A pressão final é limitada pela pressão parcial dos gases inertes que não são eficientemente adsorvidos e podem sair da bomba e voltar na câmara quando a pressão estiver equilibrada, o que limita seu valor final. Mantendo uma pressão na câmara, da ordem de seis vezes a pressão parcial destes gases na bomba, os impede de voltar. A pressão parcial destes gases inertes (neônio e hélio) no ar, à pressão ambiente é de $2,3 \times 10^{-2} \mathrm{mbar}$, mas devido ao fator de compressão $\sim 150^{*}$, ela é de 3,5 mbar na bomba. Portanto, primeiro abre-se uma das bombas deixando-a agir até alcançar um valor aproximado de $20 \mathrm{mbar}$, i.e. em torno de seis vezes a pressão parcial dos gases inertes na bomba. Neste momento, a primeira bomba deve ser isolada e a segunda pode ser aberta, possibilitando pressões finais da ordem de $10^{-4} \mathrm{mbar}$.

Mais uma vez, trata-se de um sistema de bombeamento completamente limpo, que é bastante usado no lugar dos sistemas rotativos a óleo quando qualquer contaminação do ambiente por complexos de carbono precisa ser evitada. Porém, como o bombeamento depende da quantidade de zeolita presente, a pressão final é função do volume a ser bombeado, o que não é o caso com os sistemas convencionais. O uso contínuo das bombas de adsorção tende a pulverizar a zeolita, sendo difícil prevenir a entrada do elemento pulverizado no sistema de vácuo onde ele pode formar depósitos indesejáveis ou bloquear o fechamento de válvulas de metal. Nessas condições, é aconselhado recarregar a bomba com zeolita nova, toda vez que a pulverização começar a ocorrer. Devido a todos estes problemas, e ao fato que as bombas precisam ser preenchidas com nitrogênio líquido e resfriadas durante meia hora antes de serem usadas, o procedimento se torna bastante demorado, especialmente quando se trata de fazer o vácuo na câmara de crescimento (por causa de seu grande volume).

Para evitar este transtorno, estamos importando um novo sistema de bombeamento, para substituir a bomba Ventury e as duas de adsorção. É constituído por uma bomba turbomolecular de $400 \mathrm{l} / \mathrm{s}$ com todos os medidores de pressão necessários (trabalhando na faixa de 760 Torr a

Fator de compressão $=$ volume da câmara/volume da bomba $(\cong 600 \mathrm{l} / 41=150)$ 
$10^{-9}$ Torr) e uma bomba mecânica seca de $30 \mathrm{~m}^{3} / \mathrm{h}$ para realizar o pré-vácuo necessário para iniciar o funcionamento da bomba turbomolecular. O princípio de funcionamento da bomba turbomolecular é também a transferência de momento para as moléculas do gás a ser evacuado, só que desta vez ela é provocada por uma superfície sólida em rotação rápida (dezenas de milhares de voltas por minuto). As pressões podem atingir valores da ordem de $10^{-10}$ Torr sem nenhuma contaminação do ambiente por complexos de carbono, já que este tipo de bomba não emprega óleo.

\section{I.2.1.3 - Bomba iônica}

As bombas ionicas fazem parte da classe das bombas de "sorção" (o termo "sorção" sorption, em inglês, é genérico para os fenômenos de adsorção e absorção), só que a zeolita é substituída por um filme de um outro tipo de material (geralmente titânio), não poroso, que é renovado com freqüência por sputtering pelo próprio gás. São bombas de alto vácuo que precisam portanto de uma bomba auxiliar para realizar o pré-vácuo.

A forma mais simples de uma bomba iônica é ilustrada por uma célula de Penning (também chamada de cátodo frio - Figura I-7), que é muito usada como medidor de vácuo na faixa de $10^{-2}$ Torr a $10^{-9}$ Torr. Ela consiste de um ânodo central cilíndrico (polarizado positivamente), e cercado, a cada extremidade, por dois cátodos (polarizados negativamente), paralelos entre si e perpendiculares ao eixo do cilindro. Um campo magnético homogêneo de $0,1 \mathrm{~T}$ a $0,2 \mathrm{~T}$ é gerado ao longo do eixo do cilindro por um ímã permanente. Quando uma diferença de potencial da ordem de $6 \mathrm{kV}$ é aplicada entre os eletrodos, ocorre uma descarga dentro do ânodo. Os elétrons, arrancados das moléculas de gás, percorrem uma trajetória helicoidal e são recolhidos pelo ânodo, enquanto que os íons são atraídos pelo cátodo onde vão colidir em linha reta (o campo magnético tem uma fraca influência sobre a trajetória deles pois são muito mais pesados que os elétrons).

O cátodo é formado por uma chapa de titânio de alguns milímetros de espessura que será pouco a pouco evaporada por sputtering e onde os átomos ionizados penetrarão. A evaporação do cátodo nas paredes da bomba forma um filme fresco de titânio que é altamente reativo e onde serão adsorvidas as moléculas do gás ambiente que não foram ionizadas. Como o sputtering é contínuo (enquanto existir uma descarga), o filme é renovado continuamente, o que impede a saturação do bombeamento como no caso das bombas de adsorção clássicas.

A baixa pressão, a densidade de moléculas no gás é menor, o que acaba enfraquecendo a descarga e diminuindo o sputtering e o bombeamento. O papel do campo magnético externo é 
justamente aumentar o caminho dos elétrons até o ânodo (eles possuem uma trajetória helicoidal em vez de reta) o que acaba aumentando a probabilidade de ionização de outras moléculas do

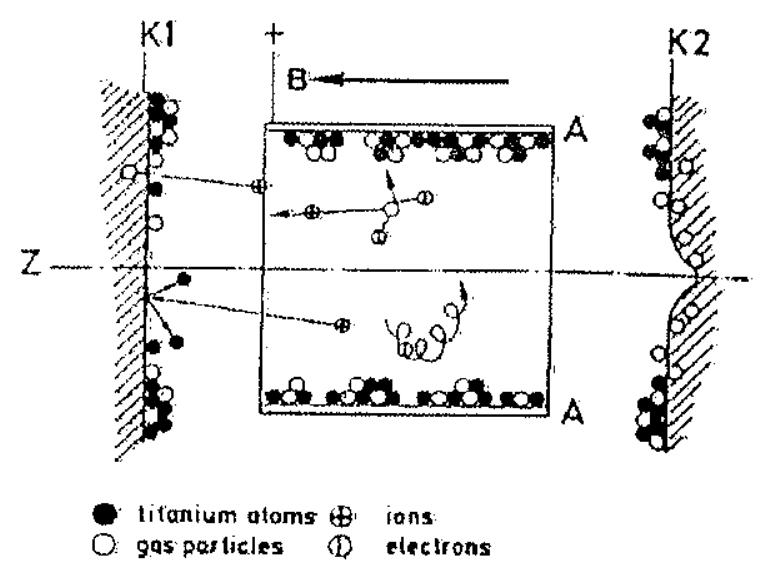

Figura 1-7 - Esquema de operação de uma célula de Penning ${ }^{17}$; KI e K2 são os cátodos de Ti, A é o ànodo cilindrico e B o campo magnético gerado por um imã permanente externo; a trajetória dos elétrons e ions é também mostrada; o bombeamento por adsorção do gás no filme de Ti ocorre em A e nos extremos de KI e K2; o bombeamento por implamação no cátodo acontece na região central (em Z) onde acontece o sputtering do Ti cratera ilustrada em $K 2$.

gás assim como a faixa de funcionamento do medidor. Uma célula de Penning em si é na verdade muito ineficiente e mal aproveitada, pois só uma pequena parte do cátodo é evaporado em volta da região central do ânodo cilíndrico. Nas bombas iônicas comuns (tipo diodo), juntam-se várias dezenas de pequenas células de Penning em paralelo para aumentar a eficiência do bombeamento (Figura Im8).

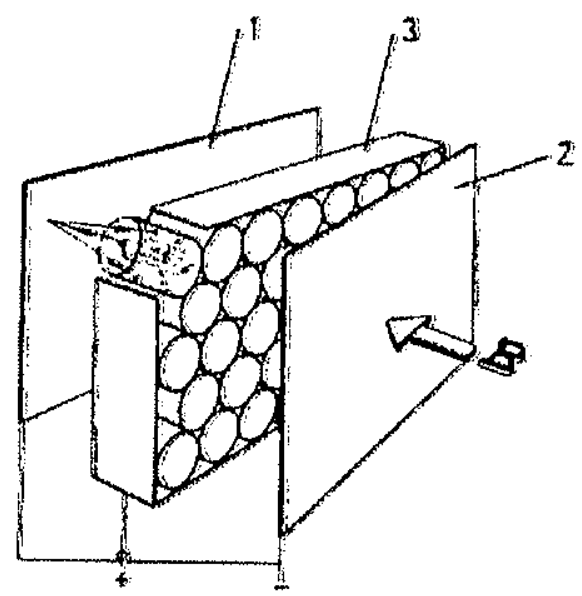

Figura 1-8 - Lsquema mostrando a construção de uma bomba iônica do tipo diodo, formada por um conjunto de várias pequenas células de Penning para aumentar a eficiência do bombeamento ${ }^{17}$; e 2 são as placas do cátodo de ti, e B o campo magnético produzido por um imã permanente externo.

O principal mecanismo de bombeamento neste tipo de bomba é a adsorção do gás sobre o filme de titânio, e não a penetração dos íons dentro do cátodo. Portanto, apesar da ionização do 
gás afetar todos os elementos da tabela periódica, a eficiência de bombeamento não é a mesma para todos eles. Os elementos reativos tais como nitrogênio, oxigênio, hidrogênio, carbono, hidrocarbonos leves e vapor de água, formam ligações covalentes com o filme de titânio evaporado e são portanto bombeados rapidamente. Outros elementos, como os gases inertes, interagem pouco com o filme de titânio e são unicamente bombeados por implantação no cátodo.

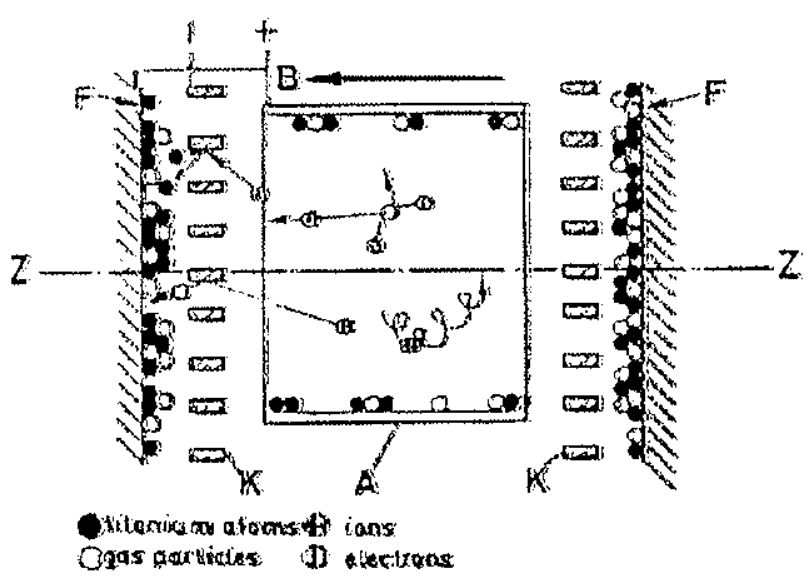

Figura I-9 - Esquema de operação de uma bomba iônica do tipo triodo ${ }^{17}$; $A$ - o anodo e F - o coletor, são aterrados; $K$ é o cátodo, na forma de grade e $B$ é o campo magnético na direção $Z ;$ o Ti é renovado com frequiência nas superficies de $A$ e $F$, pelos choques dos ions - formados no ânodo, com a grade K; a perda de energia cinética com os choques, reduz a liberação dos gases inertes, pela implantação em $F$, tornando o bombeamento mais eficiente.

O inconveniente das bombas iônicas do tipo diodo é que os gases inertes são implantados no cátodo de titânio que vai sendo evaporado lentamente pelo sputtering, liberando novamente os átomos aprisionados. Para aumentar a eficiência de bombeamento destes elementos, bombas iônicas do tipo triodo foram concebidas, onde o cátodo de titânio possui agora, a forma de uma grade e é colocado entre o ânodo cilíndrico e as paredes metálicas da bomba.

O ânodo e as paredes da bomba são aterradas por razão de segurança, o que implica que o cátodo recebe uma voltagem negativa de $6 \mathrm{KV}$. O princípio de funcionamento é similar ao de uma bomba de diodo. Os íons, gerados no ânodo, são acelerados em direção à grade onde se chocam em incidência rasante, causando o sputtering do titânio. Isso resulta na deposição de um filme sobre o ânodo A e o corpo da bomba $F$, renovando com freqüência a superfície de titânio onde os gases serão adsorvidos quimicamente. Nesse processo de sputtering no cátodo $\mathrm{K}$, os íons perdem geralmente sua carga e podem ser adsorvidos ou implantados no corpo da bomba, dependendo da energia cinética após o choque (esse é o fator importante no bombeamento de 
gases inertes). Os ions que não perderam a carga no choque inicial com o cátodo não podem chegar em F, por causa da presença do campo elétrico em sentido contrário, e retornam em direção à grade de titânio onde causarão mais sputtering. Existe um pequeno efeito de sputtering também em F, mas a taxa é reduzida devido à perda de energia cinética durante o choque com $\mathrm{K}$. Conseqüentemente, as partículas implantadas serão liberadas a uma taxa muito menor que nas bombas de diodo. Neste caso, a eficiência do bombeamento dos gases inertes é $30 \%$ (em relação ao nitrogênio), contra $3 \%$ no caso das bombas de diodo.

\section{I.2.1.t - Bombas de sublimação}

As bombas de sublimação fazem também parte da classe das bombas de "sorção" e são bombas de alto vácuo. Esse tipo de bomba é baseada no processo de adsorção sobre filmes de titânio depositados numa parede por sublimação. O titânio é usado quase que exclusivamente neste caso, pois é muito reativo, pode ser manuseado facilmente e produzido com alta pureza, e possui uma alta taxa de sublimação. Costuma-se sublimar o titânio de maneira a formar um filme fino sobre as paredes da bomba onde as moléculas de gás serão adsorvidas. Dependendo da pressão na câmara, o filme precisa ser renovado com uma certa freqüência para evitar sua saturação. Além disso, como a sublimação requer uma grande potência elétrica, a parede da bomba (ou o suporte onde o filme é depositado) precisa ser refrigerado para aumentar a eficiência da adsorção (ou para evitar a desadsorção das moléculas já adsorvidas). Como funciona por adsorção, esta bomba é muito ineficiente para evacuar os gases inertes e precisa portanto ser usada em conjunto com um outro tipo de sistema de alto vácuo (uma bomba iônica de tríodo por exemplo).

Nosso sistema MBE possui duas bombas de sublimação de titânio ligeiramente diferentes. Na câmara intermediária, três filamentos de $15 \mathrm{~cm}$ de titânio (formando uma liga com $15 \%$ de molibdênio para aumentar as propriedades mecânicas em altas temperaturas) são inseridos dentro da bomba iônica e a sublimação é realizada sobre a estrutura metálica interna da bomba iônica. Com uma corrente de $45 \mathrm{~A}$ circulando no filamento, sua a temperatura sobe até $1400^{\circ} \mathrm{C}$ e a taxa de sublimação é da ordem de $0,05 \mathrm{~g} / \mathrm{h}$, sendo que a quantidade de titânio disponível por filamento é de $1,2 \mathrm{~g}$.

Na câmara de crescimento, possuímos uma bola de titânio circundando um filamento de tungstênio dentro do qual passa a corrente que sublimará o titânio. Como o uso desta bomba é mais freqüente e mais prolongado que para o sistema da câmara intermediária, ela possui um escudo especifico, resfriado pelo sistema de água em ciclo fechado, sobre o qual o filme de 
titânio será depositado. O escudo é posicionado entre o porta-amostras e a bola de titânio para que os átomos sublimados não alcancem a zona de crescimento onde poderiam ser incorporados na amostra. A refrigeração é necessária devido à proximidade da bola de titânio (alguns centímetros) e ao seu uso freqüente e prolongado durante o crescimento e a desgaseificação das células ou das amostras. Além destes fatores, quando muitas moléculas forem adsorvidas em pouco tempo (principalmente em pressões mais altas ou quando o ambiente for muito contaminado), a adsorção libera uma grande quantidade de energia que precisa ser dissipada. Com correntes de até $55 \mathrm{~A}$, a taxa de sublimação chega a $0,5 \mathrm{~g} / \mathrm{h}$. Para aumentar a eficiência da bomba e diminuir o consumo de titânio, a unidade de controle possui um timer que possibilita o funcionamento da bomba repetitivamente durante um intervalo de tempo definido.

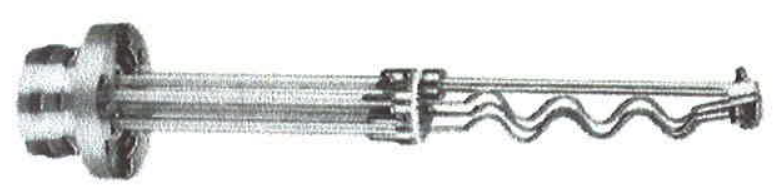

(a)

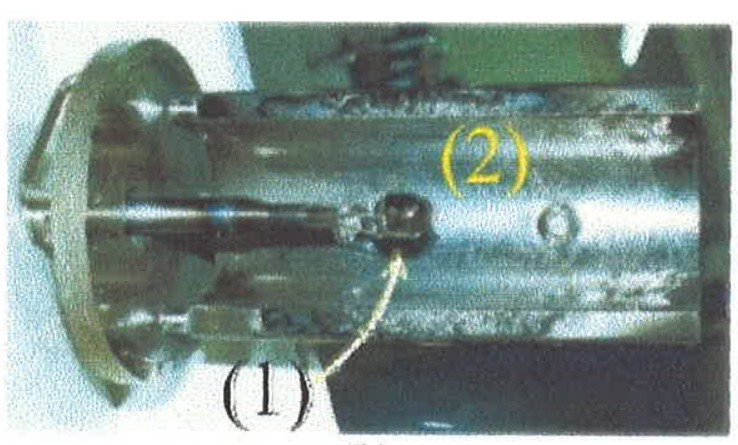

(b)

Figura I-10 - Os dois tipos de bombas de Ti utilizadas em nosso sistema: (a) a bomba da câmara intermediária com três filamentos; (b)bola de Ti(1) e escudo(2) da câmara de crescimento; devido ao uso freqüente e proximidade da bola, o escudo é resfriado pelo sistema de água em circuito fechado.

\section{I.2.1.5 - Painel criogênico}

O painel criogênico circunda completamente a região de crescimento (não a câmara de crescimento inteira - ver Figura I-4 e Figura I-11) e, durante a operação do sistema MBE, é preenchido com nitrogênio líquido. Quando é resfriado, ele funciona como uma bomba criogênica, condensando os gases com ponto de evaporação mais elevado que a temperatura do nitrogênio líquido, reduzindo assim a pressão na câmara.

O líquido criogênico é fornecido por um pequeno tanque de 10 litros, localizado acima do sistema MBE, e é injetado no painel pela força da gravidade (queda livre). Este tanque é abastecido automaticamente a partir de um reservatório de 5000 litros, externo ao laboratório, cujo nível é completado a cada 15 dias por uma empresa. O líquido criogênico circula também ente as células de efusão onde age como dissipador térmico para evitar que a temperatura de uma célula influencie as vizinhas. Este fator é muito importante para a estabilidade dos fluxos 
das partículas, pois as células de arsênio operam em torno de $250^{\circ} \mathrm{C}$ enquanto que as células dos dopantes necessitam de temperaturas variando entre $1000^{\circ} \mathrm{C}$ e $1400^{\circ} \mathrm{C}$.

A outra função importante deste painel é evitar que impurezas provenientes de uma possível desadsorção das paredes da câmara possam chegar diretamente na superfície da amostra e sejam incorporadas. Neste caso, a probabilidade de se chocarem com o painel é muito grande, e haverá conseqüentemente uma perda de energia cinética considerável com a parede fria. As únicas impurezas suscetíveis de alcançarem o substrato diretamente são aquelas oriundas das células, já que elas estão orientadas na direção dele.

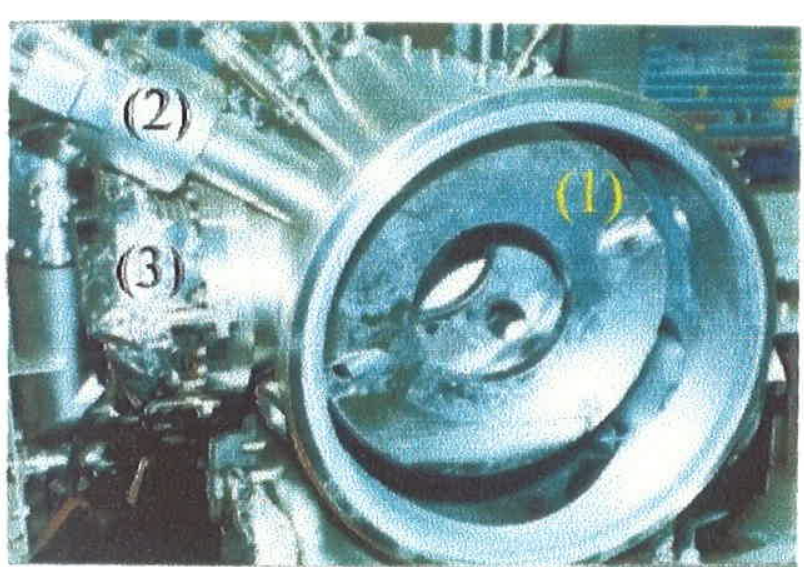

(a)

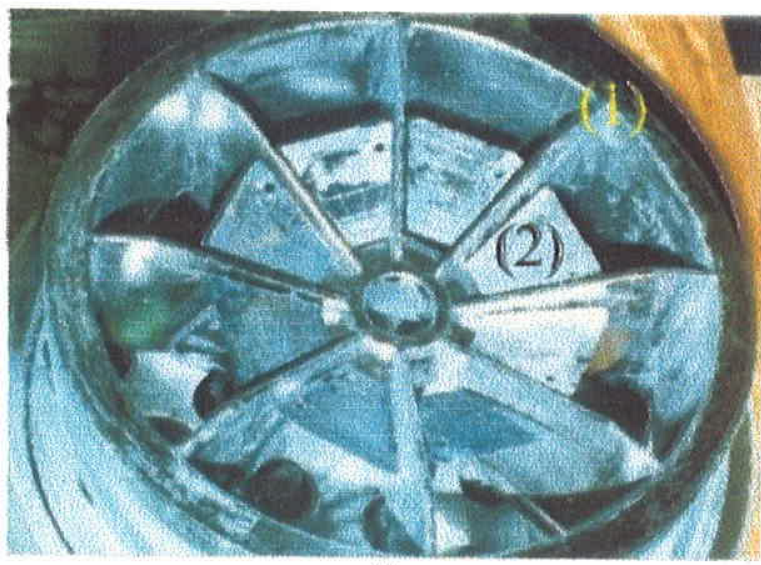

(b)

Figura I-11 - Fotos mostrando os dois painéis criogênicos independentes de nosso sistema; (a)painel que circunda a região de crescimento(1); o canhão de elétrons do sistema RHEED(2) e a flange do manipulador de substratos(3) são mostrados como referência; (b)flange dos fornos (de 18'"), mostrando o segundo painel criogênico(1) e os obturadores dos fornos(2).

Em condições normais de crescimento, o consumo de nitrogênio é da ordem de 30 litros por hora, sendo que este valor pode variar sensivelmente dependendo do número de células ligadas e da temperatura de cada uma. O abastecimento automático é muito importante para que o painel fique sempre cheio de nitrogênio líquido, o que garante uma temperatura constante e portanto, nenhuma variação da concentração de impurezas residuais que poderia alterar a qualidade das camadas epitaxiais.

\section{I.3 - Instrumentos de caracterização in situ}

\section{I.3.1 - Medidores de pressão}

Em nosso sistema MBE, utilizamos dois tipos de medidores de pressão. Para caracterizar o pré-vácuo, um medidor do tipo Pirani é necessário por causa dos altos valores da pressão. Para 
pressões mais baixas, uma célula de Bayard-Alpert é empregada.

\section{I.3.1.1 - Medidor de Pirani}

O medidor do tipo Pirani é baseado na condutividade térmica do gás presente na câmara. É constituído por um fio metálico fino (uma dezena de micrômetros) percorrido por uma corrente elétrica que o aquece por efeito Joule (Figura 1-12). A dissipação da potência elétrica é realizada principalmente pelo contato com as moléculas do gás e, portanto, depende da pressão (os outros fatores de dissipação são as perdas pelos terminais elétricos e por radiação que independem da pressão).

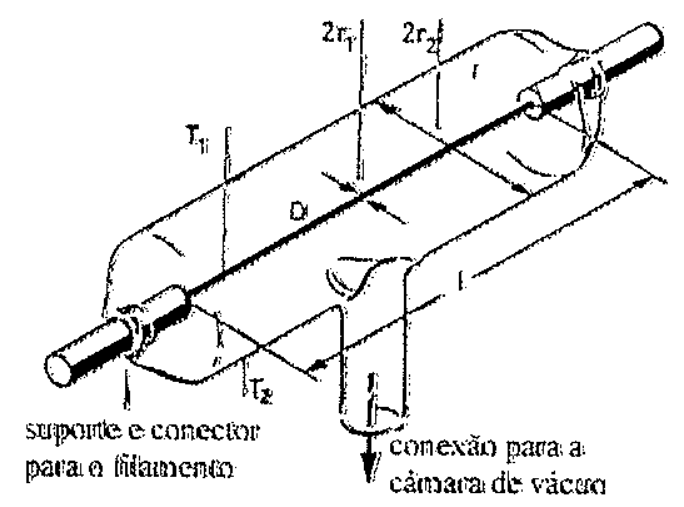

Figura I-12 - Escquema mostrando o principio de operação do medidor por condutividade térmica (medidor de Pirani) ${ }^{18}$; o fio tem um diametro $2 r_{1} \sim 5-20 \mu \mathrm{m}$ e comprimento $1 \sim 50-100 \mathrm{~mm}$ e é esticado dentro de $1 \mathrm{~m}$ tubo cilindrico de diâmetro $2 r_{2} \sim 20-30 \mathrm{~mm}$.

Para uma dada potência elétrica, a temperatura do filamento dependerá da pressão, o que influenciará diretamente sua resistência. As variações da resistência elétrica do filamento poderão então ser associadas diretamente às variações da pressão. Abaixo de $10^{-3}$ Torr, as perdas por condução térmica no gás se tornam despreziveis em relação aos outros mecanismos, e o medidor perde sua sensibilidade.

\subsection{1:2 - Medidor de Bayard-Alpert}

O medidor do tipo Bayard-Alpert é um medidor de ionização e faz parte da mesma familia que o medidor de Penning. Todavia neste caso, uma configuração diferente e voltagens mais baixas são empregadas, pois trata-se de ionizar o gás por efeito termoiônico, e não por descarga formando um plasma entre os eletrodos. Um cátodo termoiônico (que emite elétrons quando é aquecido pela corrente elétrica fluindo nele) na forma de um fio é cercado por um 
filamento em espiral constituindo o ânodo, que é por sua vez circundado por uma grade metálica cilíndrica formando o coletor de íns que se encontra a um potencial mais negativo que o ânodo e o cátodo. Os elétrons emitidos pelo cátodo são acelerados pela diferença de potencial e colidem com as partículas do gás que são ionizadas e coletadas pela grade externa (o coletor). A corrente iônica do coletor fornece portanto uma leitura direta da pressão.

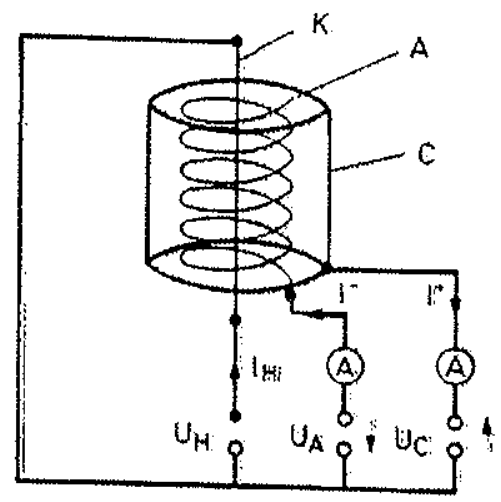

Figura I-13 - Principio de operação de um medidor de vácuo por ionização; K é o cátodo termoiônico, A o ànodo $e$ Cocoletori"

Este tipo de configuração (Figura 1-13) apresenta alguns problemas de precisão em baixa pressão, devido a efeitos parasitas tais como o aquecimento de algumas partes do medidor que liberam gases, a desadsorção de gases e íons provocada pelo bombardeamento dos elétrons, e a emissão de raios $\mathrm{X}$ moles que podem gerar elétrons extras por efeito fotoelétrico.

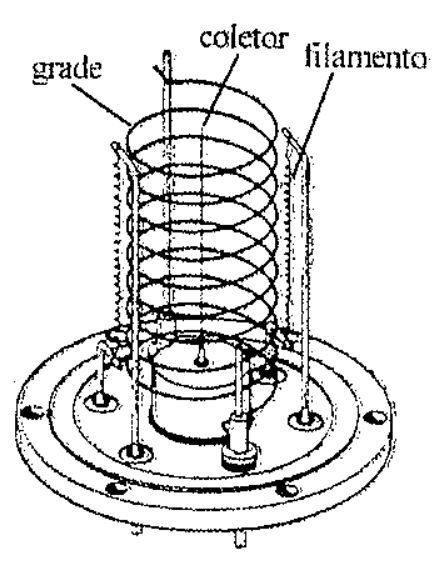

Figura I-14-Esquema dos medidores de Bayard-Alpert witizados em nosso sistema-modelo com flange ${ }^{20}$; notar a diferença de configuração com o medidor padrão (Figura I-13).

Para minimizar a influência destes efeitos e aumentar a sensibilidade deste tipo de 
medidor, Bayard e Alpert modificaram a configuração dos eletrodos e diminuiram consideravelmente o tamanho do coletor, estendendo assim, a faixa de medida até $10^{-10}$ Torr (Figura 1-14). Possuímos um destes medidores em cada câmara, mais um para medir diretamente o fluxo de partículas emanantes dos fornos.

\section{I.3.2 - Medidores de temperatura}

\section{I.3.2.1 - Termopar}

Um termopar é usado para a leitura da temperatura da amostra durante o crescimento, durante a desgaseificação na câmara intermediária e de entrada/saída, e para determinar a temperatura das células de efusão ${ }^{*}$. O termopar é baseado na diferença de coeficiente termoelétrico de dois fíos metálicos formando uma junção. Se uma das junções for mantida numa temperatura fixa de referência e a outra estiver numa outra temperatura, existirá entre elas uma diferença de potencial que será função da diferença de temperatura entre as duas junções.

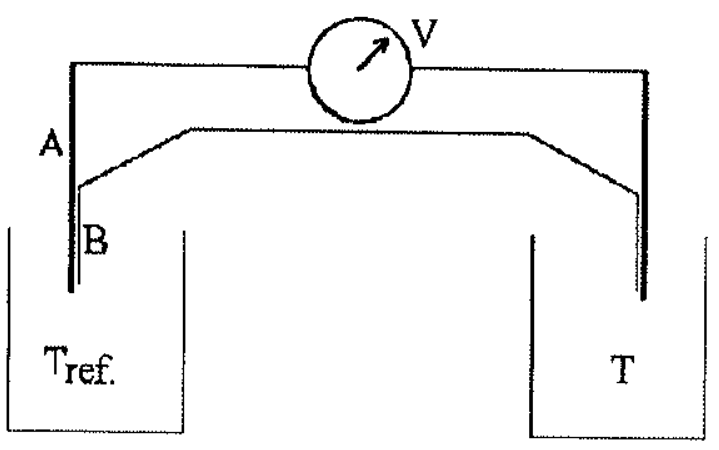

Figura I-15 - Esquema do funcionamento de um termopar; A e B são os dois fios de materiais diferentes que formam a junção e V é o voltímetro para medir a diferença de potencial que é função da diferença de temperatura entre as duas junções.

Dependendo das faixas de temperatura a serem medidas e das condições experimentais, várias combinações de elementos ou ligas podem ser usadas. Em nosso sistema, foi escolhida una liga de tungstênio e rhênio (W-Re), sendo que um dos fios possui $5 \%$ de rhênio e o outro $26 \%$. Essas ligas refratárias são adequadas para operação a temperaturas elevadas já que não reagem com os elementos presentes nas câmaras e não contaminam o ambiente.

Estes são colocados tocando o fundo do cadinho contido nas células. 


\subsubsection{2 - Pirômetro}

Um pirômetro é um sistema óptico que possibilita a determinação da temperatura pela medida da intensidade de radiação infravermelha oriunda do corpo sob investigação, sendo que a intensidade desta radiação varia com a temperatura do corpo. Trata-se de uma medida sem contato físico que pode ser realizada a distância e é muito adequada para os sistemas de vácuo. $O$ pirômetro consiste geralmente de um fotodetector, funcionando numa certa faixa de energia, que converte os fótons incidentes (cuja energia é maior que o gap do material constituindo o detector) numa corrente elétrica cuja intensidade será relacionada com a temperatura. Uma unidade de processamento recebe este sinal e o converte numa leitura de temperatura.

Um parâmetro importante deste tipo de medida é a emissividade do corpo sob investigação. Ela depende principalmente da natureza do material e da rugosidade microscópica e macroscópica de sua superfície. Por exemplo, superfícies rugosas e porosas possuem uma alta emissividade (próxima à unidade), pois se aproximam muito de um corpo negro que é um emissor ideal de radiação infravermelha a qualquer temperatura e possui uma emissividade máxima (unitária). Por outro lado, uma superficie lisa será muito refletora, e sua emissividade será baixa (temos a relação emissividade + refletividade + transmissão $=1$ ).

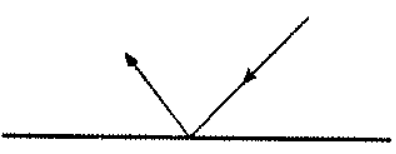

(a) superfície polida do material A

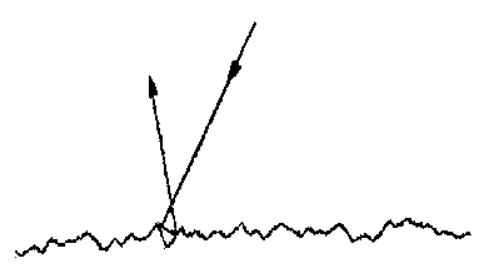

(b) superfície rugosa do material A

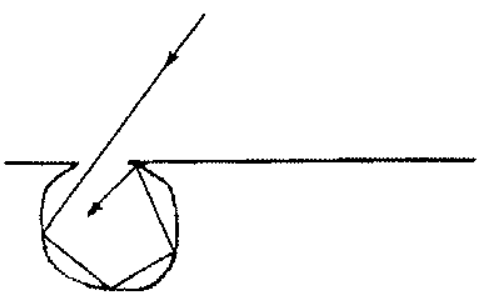

(c) cavidade do material A

Figura 1-16 - Esquema mostrando a refletividade ${ }^{21}$ das superficies de um mesmo material A; em (a) a superficie polida possui alta refletividade, portanto baixa emissividade $\varepsilon_{l} ; \mathrm{em}(b)$, a superficie apresenta menor refletividade e portanto, emissividade $\varepsilon_{2}>\varepsilon_{1}$; em (c) a superficie possui uma refletividade muito pobre se aproximando de um corpo negro onde $\varepsilon=1$.

Nosso pirômetro possui um sensor de GaAs e é capaz de medir temperaturas na faixa de $400^{\circ} \mathrm{C}$ a $1000^{\circ} \mathrm{C}$, detectando os fótons pertencendo ao intervalo de energia de $1,36 \mathrm{eV}$ a $1,29 \mathrm{eV}$ $(0,91 \mu \mathrm{m}$ a $0,96 \mu \mathrm{m})$. No caso de substratos de GaAs de $0,5 \mathrm{~mm}$ de espessura, a emissividade é bem conhecida e tabelada, valendo 0,7 .

O maior problema relacionado com o uso do pirômetro é o acesso visual à amostra através de uma janela de quartzo. Com o tempo, essa janela vai sendo coberta por um filme de arsênio que absorve parte da radiação e fornece uma leitura errada da temperatura. Precisa-se 
portanto, limpar a janela com freqüència (por aquecimento externo ou abrindo o sistema de crescimento quando for possível) ou dispor de uma janela especial (sem anel de borracha) que possa ser mantida aquecida o tempo todo para impedir a deposição de material na sua superficie ${ }^{22}$.

\subsection{3 - Espectrômetro de massa quadrupolar}

Antigamente, os espectrômetros de massa eram baseados na deflexão magnética de partículas ionizadas que entravam num detector, gerando uma corrente elétrica proporcional ao número de íons coletados pela entrada estreita do detector. Dependendo da razão entre a massa e a carga elétrica dos íons, só um tipo de elemento (ou alguns outros que eventualmente possuam a mesma razão massa/carga) tinha condições de acessar o detector (para um dado valor do campo magnético) que fornecia portanto a abundância deste elemento no gás da câmara. Este tipo de medidor era geralmente de tamanho grande e não era muito adequado para medidas in situ onde o espaço disponível é às vezes muito reduzido.

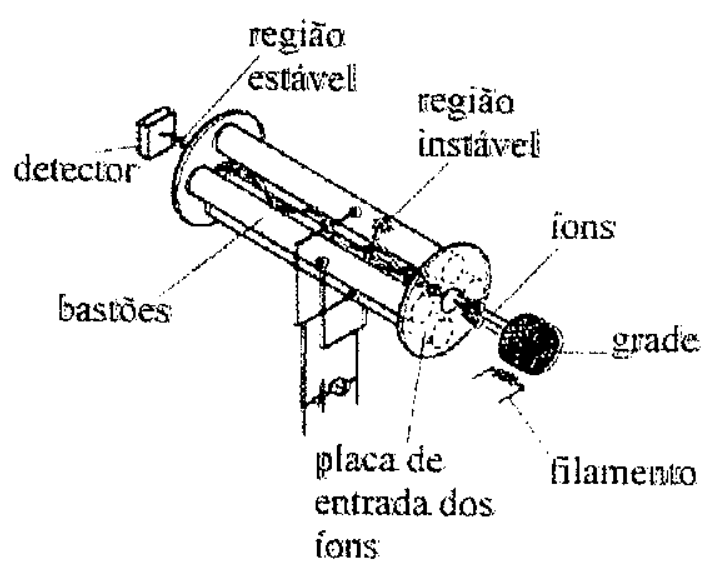

Figura I-17 - Esquema dos três estágios de um espectrômetro de massa quadrupolar; o estágio ionizador, do tipo Bayard-Alpert, é composto unicamente dos filamentos e da grade; a regiäo de filtragem é composta de 4 cilindros dispostos simetricamente, que produzem o campo eletromagnético através de voltagens continuas e de radiofreqüencia e seleciona os ions; e o detector, que coleta os ions selecionados e amplifica o sinal.

Para resolver este problema, um modelo mais compacto e ergonômico foi desenvolvido, baseado na deflexão elétrica dos íons por um sistema de quatro eletrodos paralelos alimentados por uma combinação de voltagens constantes e de radiofrequêencia. Ele é constituído por um estágio ionizador, uma região de filtragem dos íons e um detector (Figura I-17).

O ionizador é do tipo Bayard-Alpert, mas não contém o coletor central, já que a corrente lônica medida nesse lugar é formada por uma mistura de elementos ionizados (Figura I-18a). Os 
ions são acumulados no centro do ânodo e atraídos por uma placa de focalização mantida a uma voltagem negativa para iniciar a injeção do gás ionizado na região de filtragem. Essa região é constituída por 4 cilindros de molibdênio que são dispostos simetricamente e são paralelos entre si (Figura l-18b). Essa estrutura é circundada por uma chapa de aço inoxidável e possui, numa extremidade, o estágio ionizador e na outra, o detector.

As voltagens contínuas e de radiofreqüência aplicadas entre pares de cilindros produzem um campo eletromagnético que realiza a filtragem dos íons. Dependendo da amplitude da voltagem alternada (com uma frequêencia da ordem de $2 \mathrm{MHz}$ ) e da razão entre a massa e a carga dos íons, só alguns tipos conseguem atravessar a região quadrupolar. A trajetória dos outros fica instável de tal maneira que eles são expulsos da região interna do filtro, perdendo qualquer possibilidade de alcançar a entrada do detector.

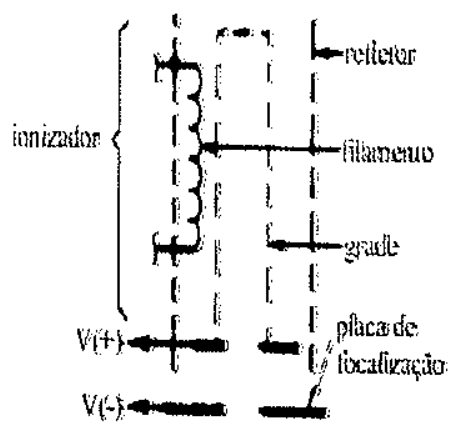

(a)

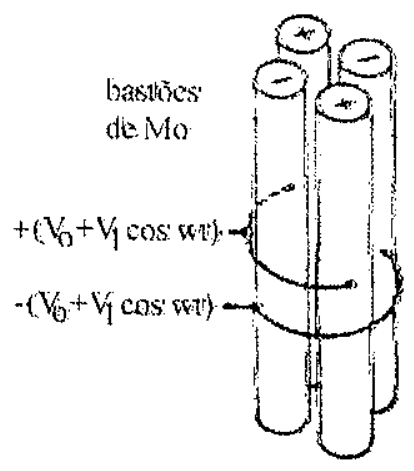

(b)

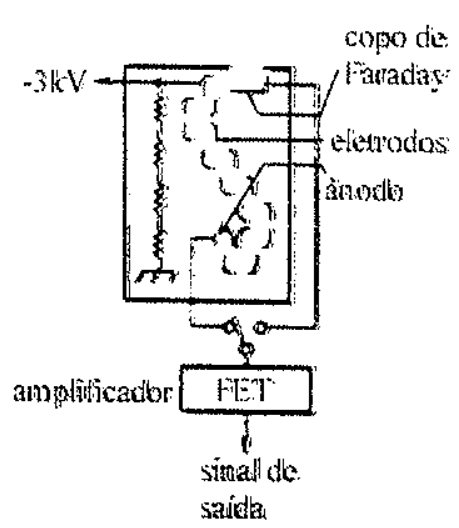

(c)

Figura l-18 - Os três estágios do espectrômetro de massa quadrupolar; no ionizador(a), os filamentos termoiônicos emitem elétrons, (que passam pela grade (positiva), ionizando os elementos em seu interior que são levados à placa de focalização para a região de filtragem(b); nesta região, os ions são selecionados pela aplicação de voltagens combinadas, e apenas os ions com uma certa razão massa/carga são estáveis na trajetória e chegam ao detector(c); nele, os ions entram em uma eletromultiplicadora que amplifica o sinal de entrada ${ }^{23}$.

Os íons que atravessaram a região quadrupolar entram no detector onde são coletados. $\mathrm{O}$ detector é constituído por uma eletromultiplicadora que possui 16 eletrodos em cascata, polarizados cada vez mais positivamente (Figura I-18c). O primeiro eletrodo da série possui uma voltagem negativa para atrair os íons que colidem com o material e extraem elétrons secundários. Estes elétrons são acelerados na direção dos outros eletrodos da eletromultiplicadora, onde, a cada colisão, produzem de um a dois elétrons suplementares que participam também da avalanche nos eletrodos seguintes. Desta maneira, cada ín incidente no detector gera, na saida, de $10^{4}$ a $10^{6}$ elétrons que podem ser medidos facilmente com um amperímetro. Esta amplificação do sinal de entrada possibilita a detecção de elementos 
possuindo uma pressão parcial de até $10^{-14}$ Torr.

Variando a amplitude da radiofreqüência aplicada nos 4 eletrodos da zona de filtragem entre $0 \mathrm{~V}$ e $2400 \mathrm{~V}$, a condição de estabilidade mudará para valores maiores da massa iônica (ou do nível de ionização), possibilitando a determinação da concentração de todos os elementos até um certo valor limite dependendo das características elétricas e físicas do instrumento. Obteremos assim um gráfico da corrente elétrica do detector em função do número atômico do elemento (ou molécula) coletado, apresentando máximos e mínimos em função de sua abundância no gás analisado (Figura I-19).

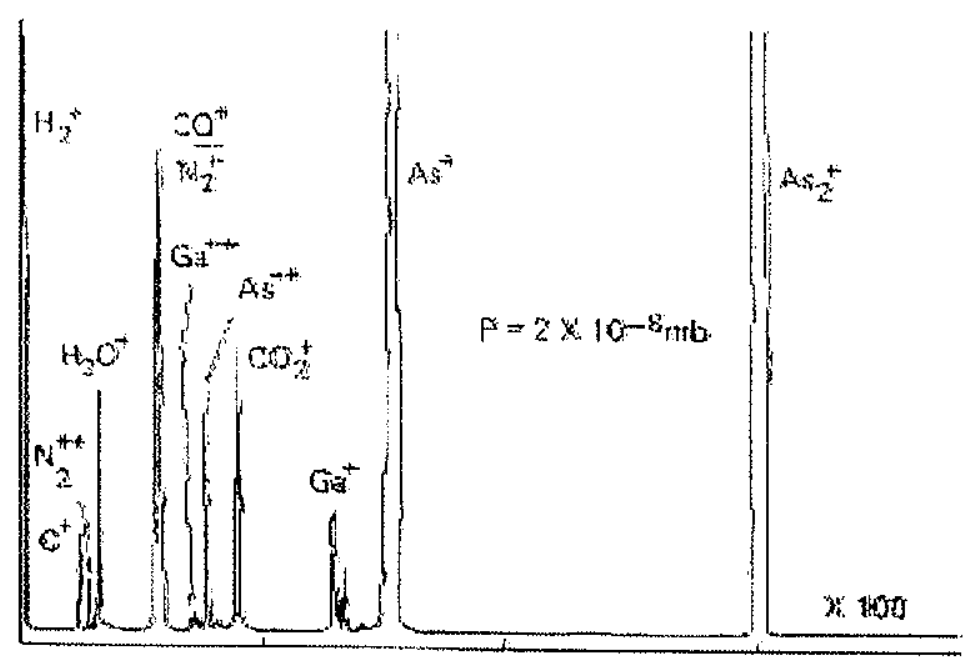

Figura 1-19 - Espectro tipico, como observado em um osciloscópio, dos vários elementos no interior da câmara de crescimento, durante o crescimento ${ }^{24}$ a altura dos picos é relacionada com a abundância de cada elemento na câmara; o eixo $x$, mosira a razão massalcarga do elemento; assim, o pico 18 corresponde ao $\mathrm{H}_{2} \mathrm{O}^{+}$e o 28 corresponde aos elementos $\mathrm{CO}^{+}$e $\mathrm{N}_{2}^{+}$.

\section{I.4 - Células de efusão de Knudsen}

As células de efusão constituem um dos componentes mais importantes de um sistema MBE, pois produzem os fluxos dos elementos a partir dos quais os filmes serão constituídos. Para obterem-se amostras com espessura e composição mais homogêneas possíveis, as células devem gerar fluxos homogêneos na superfície inteira do substrato e possuir uma excelente estabilidade em temperatura para minimizar as variações de intensidade dos fluxos com o tempo.

A efusão foi o objeto de muitos estudos no começo deste século, e Hertz, Langmuir e Knudsen ${ }^{25}$ foram os principais contribuintes para o estabelecimento das teorias relacionadas com este efeito. $O$ fenômeno de efusão diz respeito à passagem de um gás através de um orifício de 
pequeno tamanho numa parede de espessura fina (o orificio deve ser menor que o livre caminho médio das moléculas de gás e a parede deve ser infinitesimalmente fina). Neste caso, Knudsen mostrou que o corpo, sólido ou líquido, presente na célula estava em equilíbrio com seu vapor (o gás), e que a taxa de evaporação (efusão) $\Gamma_{0}$ através do orifício podia ser escrita como

$$
\Gamma_{0}=8,3310^{22}\left(p_{\mathrm{int}}-p_{k \mathrm{st}}\right) A_{o}\left(M^{\prime} T^{-0.5} \text { moléculas } \mathrm{s}^{-1}\right.
$$

onde $p_{i n t}$ é a pressão dentro da célula, $p_{e x t}$ é a pressão fora da célula ( $p_{e x t} \approx 0 \mathrm{em}$ nosso caso), $A_{0}$ é a área do orifício, $M$ é a massa da molécula ou do átomo sendo evaporado, e $T$ a temperatura interna do gás.

Uma das conseqüências mais importantes da configuração da célula de Knudsen é que a taxa de evaporação sobre o substrato é uma função cossenoidal do ângulo em relação à normal ao orifício. Isto significa que para obter uma boa homogeneidade, a amostra precisa estar incluída num ângulo sólido da ordem de 20 graus, o que define a distância mínima entre ela e a célula. Isto é muito importante quando se deseja crescer substratos de grande tamanho, já que o limite superior da distância é fixado pelo tamanho físico da câmara de crescimento. Quanto maior esta distância, melhor, tanto a nível da teoria das células de efusão, quanto a nível da possibilidade de contaminação das camadas por partículas sólidas emanantes das células.

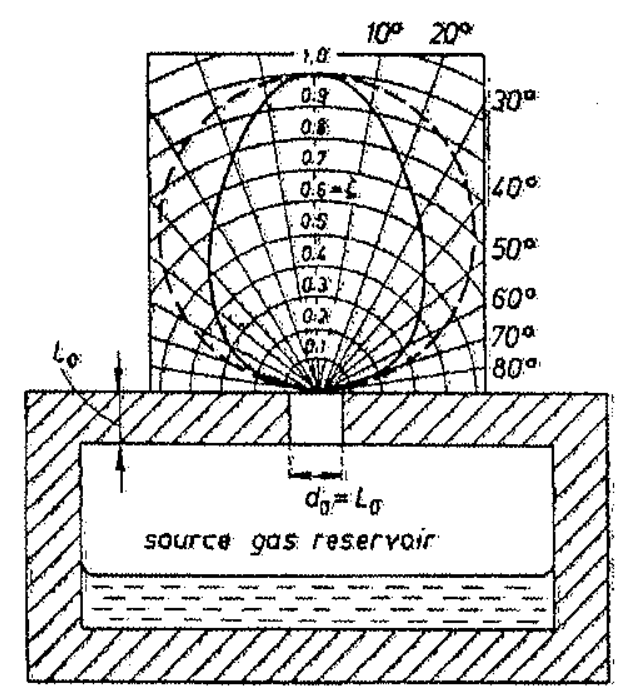

Figura 1-20 - Gráfico, em coordenadas polares, da distribuição angular das partículas do gás no processo de efusão, segundo o modelo de Clausing; o reservatório é uma célula cilíndrica com um orificio de dimensão $d_{0}$ em "ima parede de espessura $L_{0 i}$ para $L_{0}=d_{0}$ (linha contimua), a distribuição das particulas náo obedece a lei cossenoidal (linha pontilhada) ${ }^{26}$.

Na prática, as células desenvolvidas para os sistemas MBE não são células de Knudsen deais, e as relações deduzidas precisam ser corrigidas. Um modelo mais realista foi 
desenvolvido por Clausing para estudar células cilindricas com parede de espessura finita $L_{0} \mathrm{e}$ um orifício de dimensão $d_{0}$. Quando $L_{0}=d_{0}$, pode-se ver que a distribuição angular da taxa de evaporação não segue mais a lei cossenoidal. Porém, uma homogeneidade razoável pode ainda ser obtida se a amostra estiver incluida num ângulo sólido de 10 graus (Figura I-20).

Nos sistemas MBE, a forma e o tamanho das células dependem na verdade do cadinho no qual a carga sólida será colocada. As células de arsênio possuem cadinhos cilíndricos onde o tamanho do orifício e sua espessura são dados pelo diâmetro interno $d_{0}$ do cadinho e pela distância $L_{0}$ entre a superfície do elemento sólido e a borda do cadinho. Para este tipo de célula, pode ser demonstrado, usando o modelo de Clausing, que o perfil de evaporação depende criticamente da razão $L_{\alpha \gamma} d_{0}$, como indicado na Figura I-21, e que é próximo ao caso ideal quando a célula está cheia $\left(L_{0}=0\right)$. À medida que o sólido vai evaporando, o nivel de sua superfície vai baixando na célula ( $\mathrm{L}_{0}$ aumenta), o que modifica o perfil de evaporação e a homogeneidade do crescimento, pois o ângulo sólido se torna cada vez menor devido a influência das paredes.

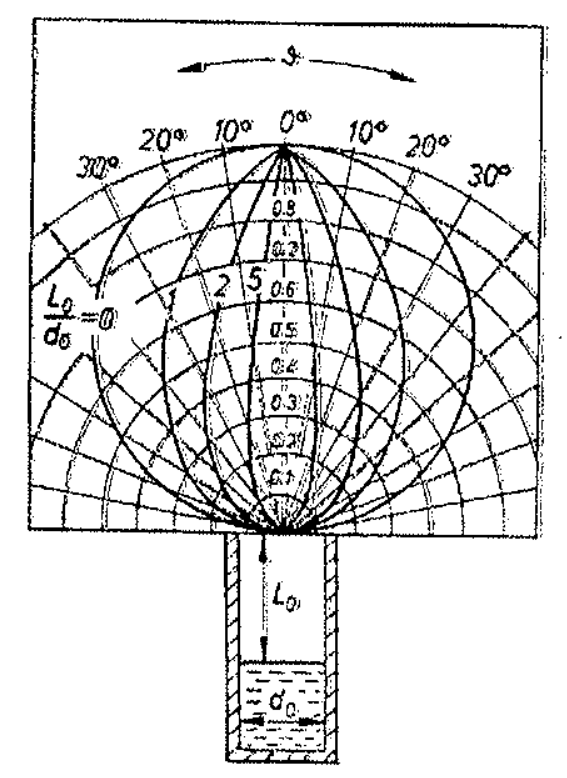

Figura I-2I - Distribuição angular, em coordenadas polares, da efusão, a partir de um reservatório cilindrico, com $L_{0}$ variando a medida que o conteúdo do reservatório vai evaporando; nota-se que o angulo sólido se torna cada vez menor devido ao aumento de $L_{0}{ }^{26}$.

Por isso, cadinhos cilíndricos são destinados a receber a carga sólida de arsênio que é usado no regime de sublimação (evaporação a partir da fase sólida). A célula de arsênio é posicionada acima do nível da amostra e está portanto orientada para baixo (ver Figura 1-5). Nessa posição, a gravidade tem a tendência a empurrar o tarugo de arsênio para fora da célula, mas ele é segurado por uma grade fixada na parte superior do cadinho. Nestas condições, o 
material está sempre acumulado na beira da célula $\left(\mathrm{L}_{0}=0\right)$, qualquer que seja a taxa de evaporação e a quantidade de arsênio sobrando.

Os elementos da coluna III (índio, gálio e alumínio) não podem ser colocados nesta posição, inclinada para baixo, pois nas temperaturas de uso $\left(600^{\circ} \mathrm{C}, 850^{\circ} \mathrm{C}\right.$ e $950^{\circ} \mathrm{C}$ respectivamente), são líquidos e escorreriam para dentro do sistema MBE. Eles precisam ser colocados abaixo do nível da amostra, com a célula orientada para cima, o que implica que com o tempo, o nível do líquido vai mudando. Nestas condições, cadinhos cilíndricos forneceriam um perfil de evaporação variando no tempo $\left(\mathrm{L}_{0} / \mathrm{d}_{0}\right.$ aumenta - Figura I-21) que prejudicaria consideravelmente a qualidade das amostras.

Para esses materiais, foram desenvolvidos cadinhos cônicos, com ângulos variáveis (geralmente entre 5 e 10 graus) dependendo do tamanho e da capacidade requeridos. Apesar de apresentarem uma homogeneidade do fluxo ligeiramente inferior a aquela de um cadinho cilíndrico, a estabilidade temporal (em função do nível do líquido) é muito maior, já que o ângulo sólido interceptando o substrato é constante e imposto pelas paredes do cadinho. $\mathrm{O}$ fato da superfície do líquido a ser evaporado ser cada vez menor implicará simplesmente numa necessidade de aumentar sua temperatura para aumentar a taxa de evaporação e manter o fluxo constante (Figura I-22).

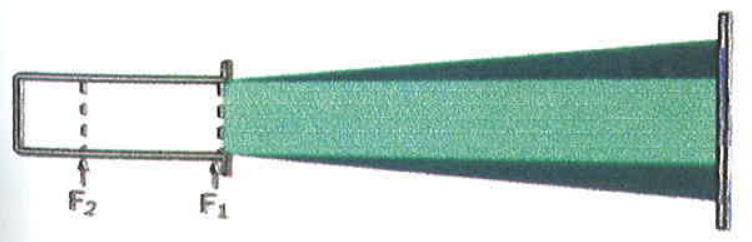

(a)

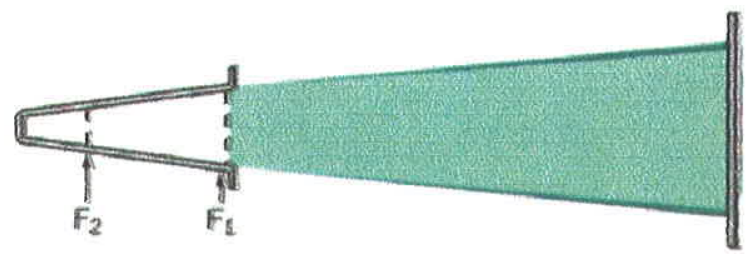

(b)

Figura I-22 - Perfil da distribuição do feixe em função da forma do cadinho e da quantidade de material restante $\left(F_{1}\right.$ e $F_{2}$ indicam o nivel de material no cadinho ${ }^{27}$; pode-se ver que, com o cadinho completamente cheio $\left(F_{1}\right)$ o perfil é o mesmo para os dois modelos, enquanto que em $F_{2}$, com o cadinho parcialmente preenchido, a uniformidade da amostra em (a) passa a ser comprometida devido à influência crescente das paredes do cadinho.

Os cadinhos destinados aos dopantes (berílio e silício) são geralmente cônicos e de pequeno tamanho, pois precisa-se de uma quantidade mínima de material em razão da baixa taxa de evaporação necessária. Nas temperaturas de uso, eles são sólidos e podem portanto ser colocados em células orientadas para baixo.

Todos os cadinhos são fabricados a partir de nitreto de boro pirolítico (PBN, pyrolitic boron nitride), que é uma cerâmica refratária que pode ser produzida com alto nível de pureza $(10 \mathrm{ppm})$. Esse material pode ser aquecido até $1400^{\circ} \mathrm{C}$, sem problema algum de desgaseificação, 
o que é ideal para um sistema MBE, já que a temperatura mais alta necessária está na faixa de $1350^{\circ} \mathrm{C}$ para o silício. Acima de $1400^{\circ} \mathrm{C}$, o PBN começa a se dissociar e emitir uma grande quantidade de nitrogênio. Todavia, a presença de nitrogênio no sistema ainda não se mostrou prejudicial à qualidade das camadas epitaxiais.

Costuma-se chamar de célula de efusão não só o cadinho contendo a carga de material, mas sim o conjunto completo, consistindo do cadinho, do sistema de aquecimento e controle da temperatura e da estrutura metálica. Como o fluxo de material deve ser o mais homogêneo possível, para produzir camadas de espessura constante no substrato inteiro, o aquecimento do cadinho e sua estabilidade são fundamentais. Uma fonte estabilizada (com retroação do tipo P, I e D) gera uma corrente elétrica num filamento metálico refratário (geralmente tântalo, pois desgaseifica pouco nas temperaturas usuais) que circunda o cadinho e o aquece homogeneamente. Para minimizar as perdas de calor por radiação (é o mecanismo de transferência de calor de maior importância no vácuo) com a estrutura metálica, o cadinho e o filamento são isolados do resto por folhas de tântalo reduzindo a temperatura externa abaixo de 70 graus (mesmo quando a carga está em $1350^{\circ} \mathrm{C}$, como no caso do silício). A leitura da temperatura é realizada por um termopar que é mantido em bom contato térmico, pois é montado sobre um mecanismo de molas fazendo pressão contra o fundo do cadinho.

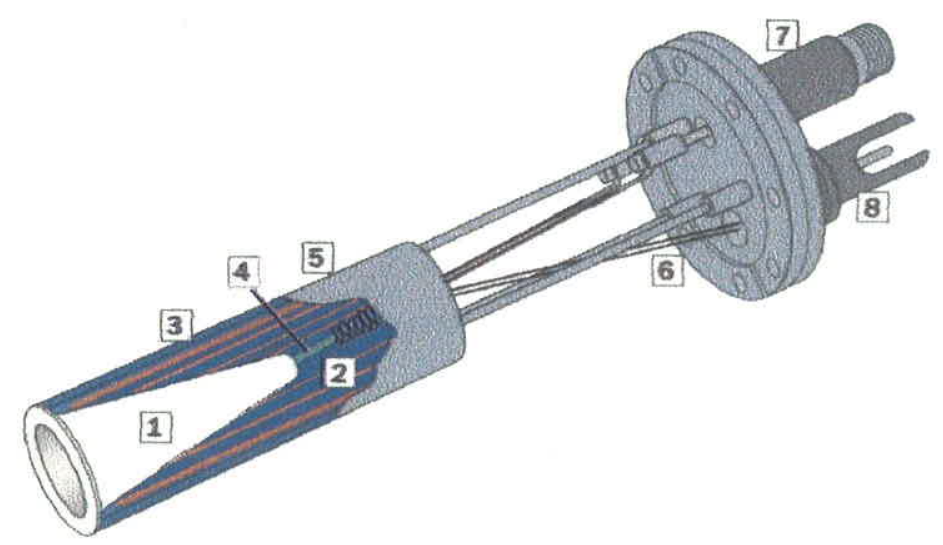

Figura I-23 - Esquema das células de efusão utilizadas em nosso sistema; (I)cadinho cônico de PBN que contém o material a ser evaporado; (2)os filamentos de tântalo (em vermelho) para o aquecimento; (3)camadas de tântalo para o isolamento térmico; (4)o termopar, tocando o fundo da célula, é fixado a um sistema de molas; (5)folha de tântalo da parte externa da célula; (6)flange de 4,5"'; (7)conector elétrico; (8)conector para o termopar.

Vários aspectos da concepção das células de efusão ainda causam sérios problemas. Um deles está relacionado com o aquecimento homogêneo do cadinho (o calor dissipado pelos filamentos é o mesmo em cada parte da superfície do cadinho). Devido ao grande tamanho do orifício, existe um gradiente de temperatura que favorece a condensação de material na saída, o 
que provoca o estreitamento do orifício e uma mudança no perfil de evaporação. Uma conseqüência mais grave é que uma parte do material condensado pode cair para dentro do cadinho, o que provoca turbulências no líquido (pois o condensado é mais frio), resfria localmente a superficie e portanto modifica o valor do fluxo ${ }^{28.29 .30}$. No caso da célula de gálio, foi demonstrado que pequenos aglomerados de gálio podiam ser ejetados e alcançar o substrato, onde constituíam a semente de um defeito oval ${ }^{3 !}$, muito prejudicial para os dispositivos eletrônicos. Para minimizar estes efeitos, novas células foram concebidas com uma densidade maior de filamentos na saída para diminuir o gradiente de temperatura e evitar a condensação.

A célula de alumínio apresenta um outro problema, relacionado com a tendência deste material a entrar, por ação capilar, dentro da estrutura lamelar do PBN. Após várias solidificações e liquefações do material (quando se liga e desliga a célula), o cadinho pode apresentar rachaduras pelas quais o líquido poderá escorrer, caindo dentro da estrutura metálica da célula e danificando-a irremediavelmente. Para evitar esse problema, cadinhos especiais com parede dupla são fornecidos. Uma maneira de minimizar este efeito é realizar a transição de fase sólido-líquido, suavemente, variando a temperatura a uma taxa de $2^{\circ} \mathrm{C}$ por minuto entre $620^{\circ} \mathrm{C}$ e $700^{\circ} \mathrm{C}$ (o ponto de fusão do $\mathrm{Al}$ é $660^{\circ} \mathrm{C}$ ). Uma rotina do programa de controle do sistema $\mathrm{MBE}$ foi dedicada exclusivamente à subida e descida da temperatura desta célula.

\section{I.5 - Sala limpa}

\section{I.5.1 - Descrição}

A sala limpa é um lugar muito importante, pois é nela que se realiza toda a preparação das amostras para o crescimento, assim como a limpeza ou o conserto dos vários instrumentos, equipamentos ou peças que pertencem à parte interna do sistema ou que chegam a entrar em contato com ela. Para preservar a integridade do ultra alto vácuo presente nas câmaras e minimizar a contaminação, a sala limpa é equipada de uma capela com exaustor e fluxo laminar, um circuito de água deionizada, um circuito com nitrogênio gasoso filtrado, dois outros sistemas de fluxo laminar acima do sas de entrada do sistema MBE, e reagentes de grau eletrônico para realizarem-se as limpezas e ataques químicos necessários.

É na capela que a maior parte das tarefas são realizadas. O exaustor, colocado na parte inferior, leva para fora todas as emanações de gases ou vapores tóxicos produzidos durante os procedimentos. O fluxo laminar renova o ar presente na capela, filtrando-o de todas as partículas 
eventualmente presentes no ambiente. O ar é injetado pela parte superior da capela, com uma baixa velocidade $(0,4 \mathrm{~m} / \mathrm{s})$ para manter-se no regime laminar, de maneira a providenciar um ambiente limpo e sem turbulências.

O circuito de água abastecendo a sala possui dois filtros mecânicos porosos que eliminam as sujeiras (areia e partículas sólidas com tamanho superior a $5 \mu \mathrm{m}$ ) provenientes da água de rua. Em seguida, a água passa por um trocador de íons e um filtro de osmose reversa que mata os organismos vivos e os impede de proliferar. Esta água possui uma resistividade da ordem de $2 \mathrm{M} \Omega \mathrm{cm}$ e é armazenada num reservatório de 50 litros. Na hora de ser utilizada, ela passa por um estágio final de deionização que leva sua resistividade a $18,2 \mathrm{M} \Omega \mathrm{cm}$ a $25^{\circ} \mathrm{C}$. Este sistema é automatizado para que, quando o nível de água no reservatório estiver abaixo de um certo valor, um sensor ligue o sistema de osmose reversa que completa o tanque numa taxa de 10 1/h. Da mesma forma, quando a água não for usada por mais de duas horas, uma limpeza do circuito interno é efetuada para evitar contaminação e proliferação de organismos vivos.

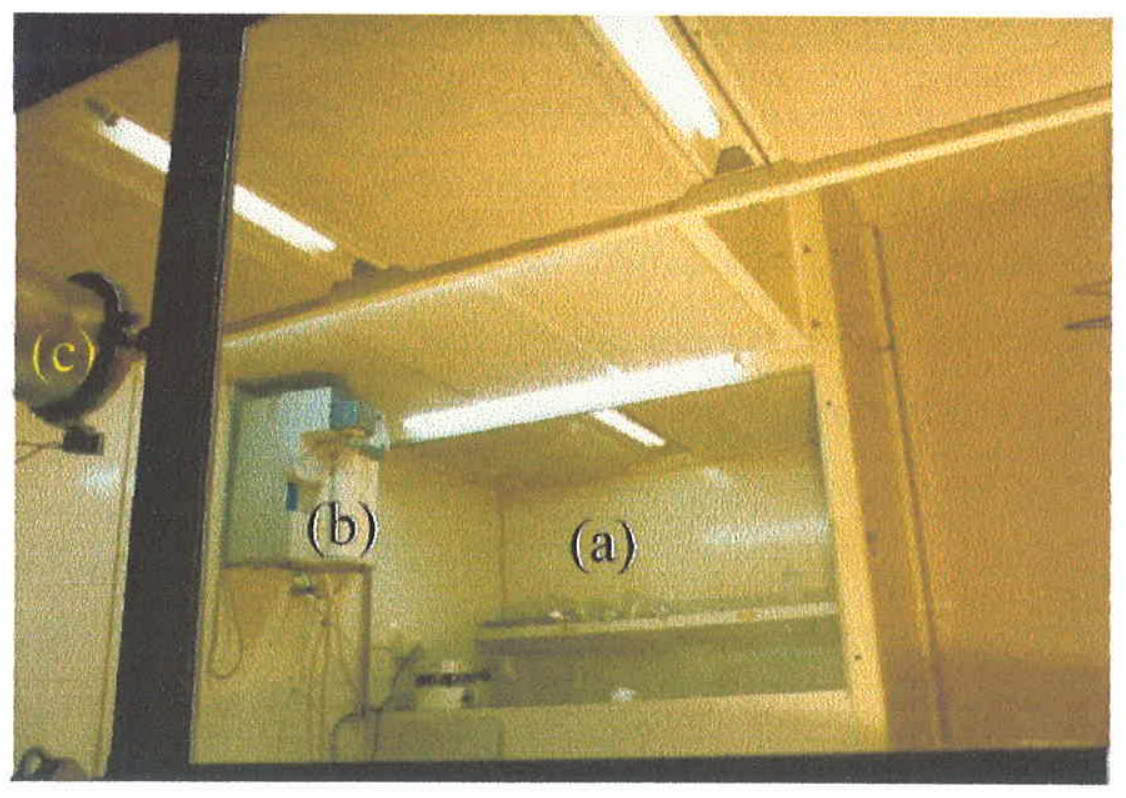

Figura I-24 - Foto do interior da sala limpa do LNMS, usada para a preparação e colagem das amostras e limpeza de instrumentos, antes de serem inseridos no sistema MBE; são mostrados os fluxos laminares no teto da sala; (a)capela, com um fluxo laminar no teto e um exaustor na parte inferior; (b)filtro para o estágio final de deionização da água; (c)extremo da câmara de entrada/saida com o sas.

Os dois outros fluxos laminares são colocados lado a lado, entre a capela e o sas da câmara de entrada/saída, para que as amostras ou peças limpas na capela possam ser introduziḍas dentro do sistema MBE sem serem contaminadas. Os três fluxos são da classe 100, 0 que significa que 1 pé cúbico de ar, dentro do fluxo, contém no máximo 100 partículas de diâmetro maior que $1 \mu \mathrm{m}$. 


\section{I.5.2 - Limpeza dos substratos}

A limpeza dos substratos de GaAs é a tarefa realizada com mais freqüência, pois é necessária toda vez que novas amostras precisam ser crescidas. Esse procedimento é realizado uma a duas vezes por semana, dependendo do número de amostras a serem crescidas e da complexidade de cada uma. Um substrato comercial de GaAs de duas polegadas pode ser cortado em 10 pedaços de tamanho similar $\left(\approx 2 \mathrm{~cm}^{2}\right)$ que serão colados individualmente sobre blocos de molibdênio e introduzidos simultaneamente na câmara de entrada/saída. A limpeza pode ser dividida em duas fases - a limpeza orgânica e o ataque químico - e é realizada com reagentes de grau eletrônico, i.e. que possuem um altíssimo grau de pureza e um número mínimo de partículas macroscópicas em suspensão.

A limpeza orgânica é constituida pelos passos seguintes:

- duas imersões consecutivas de 1 minuto em tricloroetileno em ebulição;

- duas imersões consecutivas de 1 minuto em acetona em ebulição;

- duas imersões consecutivas de 1 minuto em metanol em ebulição.

Esse procedimento é necessário para remover os produtos que foram usados durante o corte e o processamento dos substratos na fábrica ou qualquer contaminação posterior. $O$ tricloroetileno remove os contaminantes orgânicos e é removido da superficie pelo banho em acetona. A acetona costuma deixar um depósito branco, e portanto precisa ser removida (sem ter a possibilidade de secar) pelos banhos em metanol que evapora sem problema ou pode ser removido por um jato de nitrogênio gasoso.

A limpeza química é utilizada quando se suspeita de uma contaminação das camadas superficiais do substrato (é certamente o caso após o corte dos substratos na fábrica). Nesse caso, o procedimento seguinte é adotado, após a limpeza orgânica:

- imersão em ácido clorídrico $(\mathrm{HCl})$ por 1 minuto;

- imersão em água deionizada corrente por 5 minutos;

- secagem com nitrogênio gasoso;

- imersão em $\mathrm{H}_{2} \mathrm{SO}_{4} / \mathrm{H}_{2} \mathrm{O}_{2} / \mathrm{H}_{2} \mathrm{O}(5 / 1 / 1)$ por 1 minuto;

- imersão em água deionizada corrente por 10 minutos;

- secagem com nitrogênio gasoso.

$\mathrm{O}$ banho em $\mathrm{HCl}$ remove a camada de óxido sem atacar o GaAs. Isso é necessário, pois esta camada não possui uma espessura constante e poderia causar uma inhomogeneidade no ataque químico posterior. O banho em água é destinado a remover os complexos de cloro 
presentes na superfície. A água presente na amostra precisa ser evacuada por um jato de nitrogênio para não atrapalhar o ataque químico. A solução $5 / 1 / 1$ remove em torno de $1 \mu \mathrm{m}$ de GaAs por minuto ${ }^{32}$, e pode ser usada por mais tempo se há suspeita de contaminação mais profunda. O segundo banho em água é mais demorado, pois foi demonstrado que complexos a base de enxofre podiam permanecer na superfície e estavam na origem de alguns tipos de defeitos ovais ${ }^{33,34}$.

Após a limpeza do substrato, ele é clivado em 10 pedaços com a ajuda de um diamante. Cada um dos pedaços é colado individualmente sobre um bloco de molibdênio que poderá ser manuseado pelos transferidores da câmara intermediária. A colagem é realizada com índio. Para que isso seja possivel, o bloco precisa ser aquecido até $200^{\circ} \mathrm{C}$ para que o índio possa derreter e imobilizar a amostra por tensão superficial. Além de realizar a fixação das amostras, o índio providencia um excelente contato térmico com os blocos de molibdênio. Após a colagem das 10 amostras, os blocos são colocados no carrinho (ver Figura I-2) e introduzidos dentro da câmara de entrada/saída. Anteriormente, ela precisa ser colocada à pressão ambiente por introdução de nitrogênio gasoso. Durante a abertura, uma pressão positiva é estabelecida para minimizar a entrada de ar e de partículas dentro do sistema.

Quando substratos do tipo epi-ready (cuja limpeza foi feita na fábrica) são empregados, eles podem ser colados e introduzidos diretamente na câmara de entrada/saída, pois o tratamento dado na fábrica é realizado em condições de limpeza otimizadas. Cada substrato é embalado separadamente em ambiente limpo e inerte e possui uma garantia de 3 meses. Após o vencimento, eles são suscetíveis de apresentar uma contaminação, devido ao contato prolongado com a embalagem plástica ou a uma penetração de ar ambiente por difusão lenta através do envelope selado.

\subsection{3 - Limpeza dos blocos de molibdênio}

Com o tempo de uso, os blocos de molibdênio são cobertos por uma camada espessa de indio e de material proveniente das células de efusão que acaba dificultando a colagem, prejudicando a transferência de calor e a boa qualidade do crescimento. A limpeza (tanto orgânica quanto química) usada para os substratos pode ser aplicada integralmente ao caso dos blocos, sendo que o banho de $\mathrm{HCl}$ serve principalmente para remover o índio usado para a colagem dos substratos. Todavia, em vez da solução química a base de ácido sulfúrico, costumaSe usar uma solução de bromo e metanol. Dependendo da quantidade de material a ser removido, uma solução de $3 \%$ a $7 \%$ em bromo pode ser preparada (o menor teor possui uma coloração de 
chá claro, enquanto que o outro parece mais escuro). O ataque é geralmente realizado num banho ultra-sônico para aumentar sua eficiência e acaba quando o bloco recuperou seu aspecto brilhante, devido à aparência metálica do molibdênio. Eles são finnalmente mergulhados em dois banhos consecutivos de metanol, para remover o bromo, e secados com nitrogênio gasoso. Após este procedimento, os blocos são introduzidos na câmara de entrada/saída onde são desgaseificados, junto com o carrinho, por uma hora a $200^{\circ} \mathrm{C}$, e transferidos na câmara intermediária, onde são desgaseificados individualmente a $1000^{\circ} \mathrm{C}$ por 30 minutos.

\section{I.5.4 - Novos blocos de molibdênio}

Recentemente, adquirimos novos blocos de molibdênio que não necessitam o uso de índio para a colagem das amostras. Além do ganho de tempo, o substrato não precisa mais ser aquecido, o que minimiza sua oxidação superficial, e é montado com sua superficie orientada para baixo, o que o protege de qualquer contaminação.

No novo bloco (do tipo EPI Uniblock ${ }^{35}$ ), a placa central de molibdênio é removivel e possui um orifício com o formato do substrato (quadrados de $1 \mathrm{~cm}$ ou $2 \mathrm{~cm}$ de lado, quarto de wafer de duas polegadas e wafer inteiro), mas de tamanho ligeiramente inferior. O substrato é posicionado, face para baixo, em cima do orificio, e preso por uma segunda placa (de safira) que é fixada contra a primeira por um anel de pressão. Esta configuração propicia um aquecimento mais direto, pois a amostra é aquecida por radiação através da placa de safira que homogeneiza também a temperatura. Em conseqüência, a potência elétrica necessária é inferior, o que diminui a desgaseificação dos filamentos e a contaminação do ambiente.

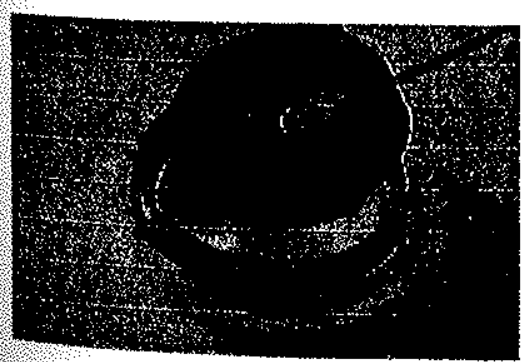

(a)

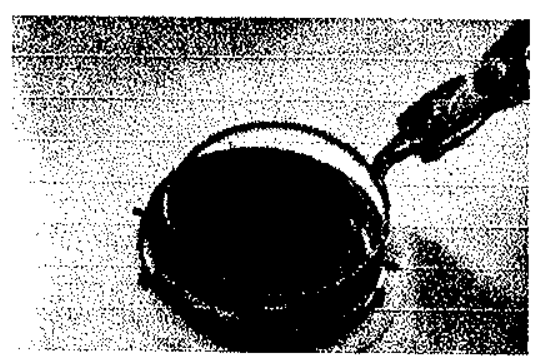

(b)

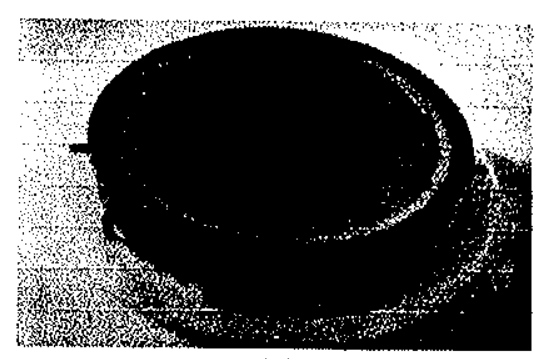

(c)

Figura I-25 -. Preparação de um substrato inteiro com os novos blocos de molibdênio; (a)o substrato é colocado, com a face para baixo, sobre o novo bloco; (b) colocação do anel de pressão - nessa configuração, não é mostrada a placa de safira; (c)o resultado final, com a face da amostra para cima ${ }^{35}$. 


\section{I.6 - Abertura}

Todo ano, antes do recesso de Natal, costumamos abrir o sistema MBE para limpeza, manutenção e recarga das células de efusão. Aproveitamos então o recesso para deixar o sistema em baking durante algumas semanas, para melhorar a qualidade do vácuo que foi prejudicada pela entrada de ar durante o tempo de abertura. Em seguida, procedemos à desgaseificação das células, das bombas de sublimação de titânio, dos fornos de amostras da câmara intermediária e de crescimento, assim como dos filamentos dos medidores de pressão e do canhão de elétrons. Após esta fase, a taxa de evaporação das células precisa ser calibrada (já que elas foram recarregadas) por medidas de efeito Hall (para os dopantes) e RHEED (para os demais materiais), e algumas amostras testes são crescidas para conferir o estado do sistema.

Essa estratégia de abertura anual programada é muito importante para otimizar o tempo de funcionamento do sistema inteiro. Alguns componentes possuem um tempo de vida médio de um a dois anos, o que levaria a várias aberturas no mesmo ano e paralisaria o crescimento por vários meses. Além do enorme desperdício de tempo, isto acarretaria num aumento considerável do custo de manutenção, já que a cada abertura as cargas e os cadinhos precisariam ser trocados para manter a alta pureza das camadas epitaxiais. Portanto, nossa abertura anual é puramente preventiva sendo que, nessa ocasião, os elementos com tempo de vida mais curto são trocados. São estes, os cadinhos e suas cargas, os filamentos dos medidores de pressão da câmara de crescimento, a bola de titânio, o filamento do canhão de elétrons, a tela fluorescente do sistema RHEED e as molas dos transferidores.

Por tratar-se de um sistema de ultra alto vácuo, alguns cuidados precisam ser tomados antes da abertura propriamente dita das flanges. Todas as bombas de alto vácuo precisam ser isoladas pelas válvulas gaveta para que elas possam continuar funcionando. Para colocar o sistema à pressão ambiente, costuma-se injetar nitrogênio gasoso que será adsorvido nas paredes e diminuirá consideravelmente a adsorção do vapor de água que é muito mais dificil de ser removido posteriormente. Além disso, mantém-se uma pressão maior dentro da câmara, para minimizar a entrada de ar durante a abertura das flanges.

Para ter acesso ao interior das câmaras, várias flanges ou janelas podem ser removidas, pelas quais o usuário pode passar as mãos ou os braços e alcançar qualquer região interna. Os consertos são realizados em primeiro, deixando para o final a troca dos cadinhos. O sistema é então fechado, e as bombas de pré-vácuo e alto vácuo acionadas seqüencialmente.

As câmaras que foram abertas são bombeadas durante a noite inteira, para que o dia seguinte a desgaseificação dos novos cadinhos possa ser realizada até $1600^{\circ} \mathrm{C}$, no caso dos 
dopantes, e $1250^{\circ} \mathrm{C}$ para os outros. O painel criogênico e a bomba de sublimação de titânio precisam estar funcionando, pois a desgaseificação de todas as células é realizada simultaneamente, o que acaba produzindo um aumento rápido da pressão na câmara. Como o painel criogênico foi utilizado, qualquer abertura precipitada da câmara de crescimento congelaria todo o sistema, correndo o risco de acumular água no seu interior. Portanto, as cargas dos elementos são colocadas nos cadinhos respectivos no dia seguinte, após o painel criogênico ter voltado à temperatura ambiente.

Os dopantes precisam ser carregados antes dos outros materiais para serem derretidos e aderidos nos cadinhos. Os cadinhos de Si e Be são carregados, tampados e recolocados no sistema numa posição inferior. O vácuo é estabelecido e a temperatura desses fornos pode ser elevada até $1600^{\circ} \mathrm{C}$ para que ocorra a fusão dos materiais. A tampa, também de PBN, possibilita o aquecimento a temperaturas mais elevadas. No dia seguinte, os outros elementos podem ser carregados normalmente.

Os dopantes e o arsênio são geralmente carregados sem nenhum tratamento químico prévio. Os elementos da coluna III precisam ser limpos, pois podem ter sido contaminados pela embalagem plástica ou oxidados. A limpeza orgânica é aplicada, seguida por um banho em ácido clorídrico por alguns minutos, um enxágüe em água deionizada corrente e uma secagem com nitrogênio gasoso. Cuidados especiais devem ser tomados durante a limpeza do gálio, cujo ponto de fusão é de $29,8^{\circ} \mathrm{C}$, para que ele não derreta.

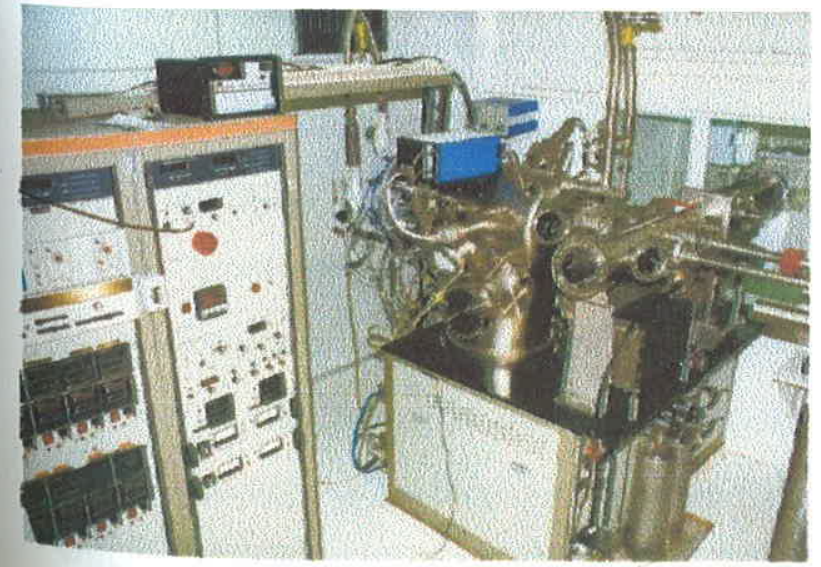

(a)

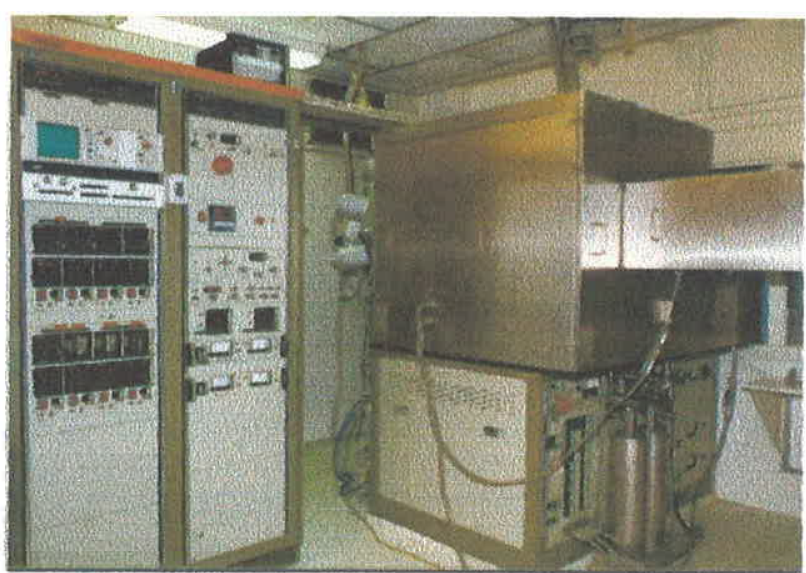

(b)

Figura I-26 - Fotos mostrando a máquina MBE (a)em operação e (b)em baking, com os painéis para o aquecimento e isolamento térmico.

Uma vez que o sistema estiver completamente fechado, ele é bombeado durante a noite inteira, e no dia seguinte é testado para verificar a presença de vazamentos. Um pequeno fluxo de hélio gasoso é passado em todas as flanges e janelas que foram abertas, observando-se a 
intensidade do pico de hélio no espectrômetro de massa da câmara de crescimento. Caso, nenhum vazamento seja detectado, o sistema inteiro pode ser colocado em baking por um certo tempo. Para isto, ele é coberto por uma série de painéis de aquecimento e isolação térmica que elevarão sua temperatura até $200^{\circ} \mathrm{C}$ (Figura I-26). Esse processo térmico é muito importante para recuperar o vácuo na faixa de $10^{-10}$ Torr, pois, durante a abertura, as câmaras estavam à pressão ambiente e suas paredes internas adsorveram numerosos tipos de gases.

Com a bomba iônica de 400 l/s ligada, a pressão alcançada na câmara de crescimento à temperatura ambiente é da ordem de $8 \times 10^{-8}$ Torr após uma abertura. Devido à presença desse alto vácuo, os gases são lentamente desadsorvidos, sendo que essa taxa de desadsorção depende do tipo de moléculas adsorvidas (via sua energia de adsorção) e da temperatura da parede. Podese demonstrar que o tempo $t$ necessário para desadsorver uma fração $f$ de uma camada de gás adsorvido numa parede na temperatura $T$ é

$$
t=\tau_{0} \ln (1 / f) \exp \left(E_{\text {des }} / R T\right),
$$

onde $\tau_{0}=10^{-13} \mathrm{~s}$ é o período da vibração das moléculas adsorvidas na superfície, $E_{\text {des }}$ é a energia molar de adsorção do gás e $R=8,314 \mathrm{~mol}^{-1} \mathrm{~K}^{-1}$ é a constante dos gases ideais. Em nosso caso, o tempo necessário para desadsorver $90 \%$ da camada de nitrogênio adsorvida $\left(E_{d e s}=170 \mathrm{kJmol}^{-1}\right)$ na parede de aço inoxidável, à temperatura ambiente, é da ordem de $2,9 \times 10^{9}$ anos. Todavia, se a câmara estiver aquecida a $200^{\circ} \mathrm{C}$, este tempo é reduzido a 16 dias. Temperaturas mais elevadas seriam mais eficazes, mas não podem ser empregadas em nosso sistema, pois as janelas são seladas com anéis de borracha que não podem ser aquecidos acima de $200^{\circ} \mathrm{C}$ sem correr o risco de apresentarem vazamentos.

A razão pela qual o nitrogênio é injetado inicialmente nas câmaras, para colocá-las à pressão ambiente, é agora muito clara. Como ele possui uma energia de adsorção menor que a do oxigênio e do vapor de água presentes no ar, ele será mais facilmente desadsorvido, o que implica que os períodos de baking necessários serão mais curtos. Na prática, monitora-se a pressão durante o baking, que aumenta rapidamente no primeiro dia, passa por um máximo, e volta a baixar lentamente. Quando as variações de pressão de um dia para o outro se tornam muito pequenas, o baking pode ser desligado. 


\section{II - Crescimento epitaxial por feixe molecular}

\section{II.1 - Considerações gerais}

A técnica de epitaxia por feixe molecular é basicamente uma técnica de evaporação no vácuo, onde feixes de átomos ou moléculas incidem sobre um substrato cristalino aquecido para formar um filme fino monocristalino possuindo a mesma estrutura que o substrato. Para obterem-se camadas de alta pureza, o sistema inteiro é constituído por várias câmaras de aço inoxidável operando no ultra alto vácuo graças a um conjunto de bombas iônicas, turbomoleculares ou criogênicas, eventualmente auxiliadas por um painel criogênico e bombas de sublimação de titânio. A presença de uma câmara de entrada é muito importante para que o vácuo da càmara de crescimento não seja contaminado pelo ar ambiente toda vez que novas amostras precisam ser introduzidas no sistema. Para que as camadas epitaxiais sejam de boa qualidade, substratos cristalinos, limpos e atomicamente lisos são empregados. A preparação química e física da superfície em cima da qual o filme será depositado é muito importante e é realizada em sala limpa com reagentes de alta pureza. Durante a limpeza, as amostras são passivadas por uma camada de óxido, o que impede a adsorção de complexos de carbono na superficie. Este processo é fundamental, pois a camada de óxido pode ser removida in situ por um tratamento térmico, enquanto que complexos de carbono são dificilmente desadsorvidos (mesmo a alta temperatura) e produzem camadas epitaxiais policristalinas ${ }^{36,37}$. Na câmara de crescimento, a camada de óxido é removida por aquecimento na presença de um fluxo de arsênio proveniente de uma das células de Knudsen. Este fluxo é necessário para repor os átomos de arsênio que são evaporados da superficie do substrato quando este estiver a uma temperatura superior a $450^{\circ} \mathrm{C}$, o que deixaria uma superfície rica em gálio imprópria para o crescimento epitaxial. A desoxidação do substrato é acompanhada pelo pirômetro e ocorre a $580^{\circ} \mathrm{C}$, quando o padrão difuso observado na tela do sistema RHEED, devido ao filme amorfo superficial, se transforma num padrão bem nítido, típico de uma superfície limpa e cristalina de $\mathrm{GaAs}^{36}$. O substrato é desgaseificado a $630^{\circ} \mathrm{C}$ por alguns minutos e em seguida levado à temperatura ideal de crescimento do material desejado que pode variar de $500^{\circ} \mathrm{C}$ a $750^{\circ} \mathrm{C}$ no caso de um sistema operando com alumínio, gálio e índio. Os materiais são produzidos sob a forma de feixes colimados e homogêneos, oriundos de células de Knudsen contendo as cargas de alta pureza. Os feixes de dopantes e dos elementos da familia III são monoatômicos, enquanto 
que o arsênio é tetramérico no caso de células convencionais (se o arsênio for produzido por um cracker ou uma carga de GaAs, ele é então dimérico). Nas temperaturas normais de uso, fluxos de $10^{14}$ a $10^{15}$ partículas $\mathrm{cm}^{-2} \mathrm{~s}^{-1}$ são gerados, limitando as taxas de crescimento a valores da ordem de 0,1 a 1 camada atômica por segundo (ou $1 \mu \mathrm{m} / \mathrm{h}$ ). A deposição do filme é obtida pela abertura simultânea dos obturadores localizados na frente das células de efusão, possibilitandó assim a chegada dos elementos na superficie do substrato onde interagirão e serão incorporados. A qualidade do crescimento dependerá geralmente de parâmetros importantes tais como a orientação, qualidade e temperatura do substrato, assim como a razão de fluxos V/II (que é geralmente maior que 1).

A região do crescimento pode ser dividida em três zonas distintas: uma relacionada com a geração dos feixes, uma segunda com o substrato, e a terceira é determinada pela última camada superficial do substrato onde vários processos químicos e físicos ocorrem, antecipando a incorporação dos átomos incidentes no substrato. Na primeira região, há uma superposição parcial de vários feixes de materiais diferentes perto do substrato, mas não ocorre nenhuma interação entre eles já que o vácuo é muito alto, propiciando às partículas um livre caminho médio $L$ de vários metros. Por informação, $L$ pode ser estimado pela fórmula

$$
L=3,11 \times 10^{-24} T / p d^{2},
$$

onde $T, p$ e $d$ são respectivamente a temperatura, pressão e o diâmetro das moléculas constituindo o gás. A segunda região, constituída pelo substrato, é cristalina e é completamente determinada uma vez que houve incorporação. O efeito de interdifusão de átomos no substrato é geralmente desprezivel nas temperaturas usuais de crescimento. A segregação, freqüentemente confundida com a interdifusão, é um efeito de superfície (um átomo incidente da família III ocupa o lugar de um outro átomo de natureza diferente da família III pertencendo à última camada crescida) mas é pronunciada unicamente no caso do crescimento de InGaAs que não será abordado neste trabalho. Portanto, é a terceira região que é a mais vital para o crescimento, já que é nela que todos os fenômenos precursores da incorporação ocorrerão: são estes a adsorção (physisorption), a migração superficial (difusão), a dissociação das moléculas, a desadsorção, a evaporação, a segregação (quando houver) e a incorporação (chemisorption). Dependendo das condições de crescimento, alguns destes efeitos serão predominantes e influenciarão mais as propriedades finais da amostra.

A termodinâmica define o comportamento de um sistema no equilíbrio, enquanto que a cinética é relacionada com a determinação dos caminhos seguidos pelo sistema até o equilíbrio. 
Por se tratar de uma técnica de crescimento, a epitaxia por feixe molecular se realiza fora de equilíbrio. Isto é facilmente verificado pelo fato que um sistema em equilibrio deveria apresentar um estado isotérmico, o que não é o caso aqui, já que os elementos incidentes possuem cada um a temperatura da célula de onde foram emitidos (o arsênio, gálio, alumínio e silício são evaporados a $250^{\circ} \mathrm{C}, 850^{\circ} \mathrm{C}, 950^{\circ} \mathrm{C}$ e $1300^{\circ} \mathrm{C}$ respectivamente), enquanto que o substrato é aquecido numa faixa de temperatura de $500^{\circ} \mathrm{C}$ a $750^{\circ} \mathrm{C}$. Todavia, o crescimento não deve se realizar tão fora de equilíbrio quanto se pensava até recentemente, pois então não se poderia justificar a alta qualidade final das amostras. Uma grande parte da energia inicial suplementar das partículas pode ser perdida durante os mecanismos superficiais antecipando a incorporação, o que poderia significar a existência de um "quase equilíbrio" local entre a região II e II $\mathrm{I}^{38,39}$.

Um dos pré-requisitos para obterem-se camadas cristalinas de boa qualidade é que o parâmetro de rede $a$ do material depositado seja igual (ou muito próximo) ao do substrato. É por esta razão que o GaAs $(\alpha=5,6533 \AA)$ foi o primeiro ${ }^{40}$ material crescido por esta técnica, já que podia ser combinado a vontade com o AlAs $(a=5,6605 \AA)$ e formar ligas de $\mathrm{Al}_{\mathrm{x}} \mathrm{Ga}_{1-\mathrm{x}} \mathrm{As}$ cujo parâmetro de rede era no máximo diferente de $0,13 \%$ (para $x=1$ ). Desta maneira, estruturas "não tensionadas" (esta diferença de parâmetro de rede é geralmente desprezada) podiam ser elaboradas, onde camadas com gap diferente eram alternadas, providenciando sistemas com efeitos quânticos novos (super-redes, poços quânticos). Quando o material depositado não tiver o mesmo parâmetro de rede que o substrato, o crescimento inicial é realizado de forma tensionada, sendo que, até uma certa espessura crítica, o filme depositado possui o mesmo parâmetro de rede que o do substrato (ele é comprimido ou estendido lateralmente para adotar o parâmetro de rede do substrato). Acima da espessura crítica, a energia elástica armazenada na camada epitaxial é suficiente para criar deslocações na interface entre os dois materiais e permitir que a camada depositada recupere seu parâmetro natural. É o caso do crescimento de InAs $(a=6,0584 \AA)$ sobre GaAs $(\Delta a=7,2 \%)$ que possui uma espessura crítica de 1,6 monocamadas $^{41}$.

A deposição, no vácuo, de filmes finos sobre um substrato já era realizada muito antes do surgimento da técnica de epitaxia por feixe molecular. As técnicas mais empregadas eram a evaporação térmica e o sputtering. A novidade, no caso da epitaxia por feixe molecular, foi a produção controlada e precisa de feixes homogêneos, combinada com o uso de substratos cristalinos de alta qualidade assim como das técnicas de ultra alto vácuo que possibilitaram o funcionamento de instrumentos de caracterização in situ (espectrômetro de massa e sistema RHEED). Todavia, a maior influência sobre a qualidade final das amostras vem do modo de crescimento adotado e de seu controle preciso via os parâmetros de crescimento disponíveis no 
sistema MBE. Existem três modos de crescimento diferentes ${ }^{42}$ que podem ocorrer em função de considerações ligadas à energia livre da camada depositada em relação à do substrato. Se a interação entre os átomos (ou as moléculas) da camada depositada for maior que com o substrato, o crescimento será tridimensional e realizado por ilhas (modo de Volmer-Weber). No caso contrário, os átomos possuem mais afinidade com o substrato, e o crescimento será bidimensional (2d), camada atômica por camada atômica (modo de Franck-van der Merwe). Às vezes, devido a uma instabilidade intrínseca do sistema, o crescimento começa camada por camada e, após uma certa espessura, continua no modo de ilhas. Este modo, chamado de Stranski-Krastanov, era pouco encontrado até alguns anos atrás. Porém, percebeu-se que os sistemas tensionados faziam parte desta categoria, uma vez que a espessura crítica tinha sido ligeiramente ultrapassada: antes da formação de linhas de deslocações, o sistema relaxa parcialmente a energia elástica armazenada, criando ilhas coerentes (de mesmo parâmetro de rede que o substrato) espalhadas na superfície, que constituem os pontos quânticos muito investigados atualmente. No caso do GaAs e AlGaAs, o crescimento é não tensionado (a espessura crítica é da ordem de várias dezenas de micrômetros) e segue o modo bidimensional. É por isso que os filmes podem ser depositados com uma precisão extrema, já que o crescimento é realizado camada por camada, sendo que a interrupção é feita pelo obturador das células de Knudsen que possui um tempo de acionamento de $0,1 \mathrm{~s}$. A eficiência do crescimento $2 \mathrm{~d}$ é aumentada pelo aquecimento do substrato que possibilita a migração das espécies adsorvidas na superfície e a incorporação nos sítios mais favoráveis.

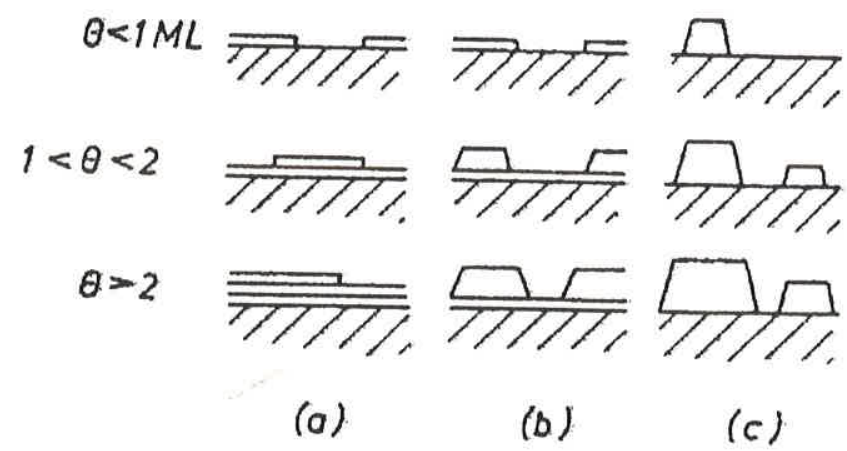

Figura II-I - Representação esquemática dos três modos de crescimento de cristais $^{42}$; (a)camada por camada (2d) ou modo de Frank-van der Merwe; (b)camada por camada seguido de ilhas ou modo de Stranski-Krastanov; (c) crescimento por ilhas (3d) ou modo de Volmer-Weber. $\theta$ representa o número de monocamadas depositadas
sobre o substrato.

O GaAs cristalino possui a estrutura cúbica da zincblende, sendo que os átomos de gálio e arsênio fazem parte de uma estrutura cúbica com faces centradas deslocada uma da outra de 
um quarto da diagonal principal. Cada átomo de gálio está ligado a quatro átomos de arsênio e vice e versa. A família de planos \{001\} é constituída por planos inteiros de átomos de gálio ou de arsênio e foi escolhida historicamente para o crescimento pois era de fácil limpeza e produzia

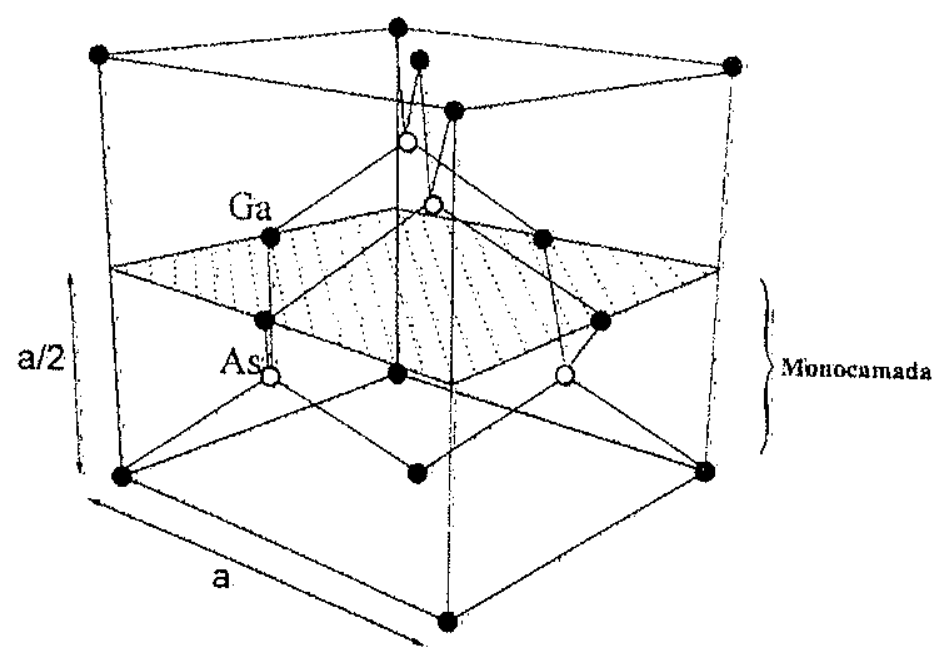

Figura II-2 - Esquema mostrando a estrutura zincblende do GaAs${ }^{43}$; sendo a o parâmetro de rede da célula convencional, observa-se que, na direção $[001]$, a distância entre duas monocamadas é igual à metade do
parâmetro de rede.

camadas epitaxiais de excelente qualidade. Além disso, esta superfície possui duas famílias de planos de clivagem perpendiculares $\{110\}$ e $\{-110\}$ que facilitam o corte dos substratos ${ }^{44}$ para aplicações em dispositivos tais como a fabricação de lasers semicondutores com cavidade de Fabry-Pérot ${ }^{45}$. Por apresentarem um número diferente de átomos de gálio e de arsênio, superfícies paralelas ao plano (001) são chamadas de polares. Serão não polares os planos, como o (110), que contiverem o mesmo número de átomos das duas espécies. Geralmente, um tarugo de várias dezenas de centímetros de comprimento é cortado em finas placas (os wafers) que serão polidas e tornar-se-ão os substratos comerciais (de uma, duas ou três polegadas) que serão usados nos sistemas MBE para depositar os filmes finos. Todavia, devido à dificuldade do processamento destes tarugos, existe sempre um pequeno erro na direção do corte que acaba provocando a aparição de alguns terraços monoatômicos na superfície. Portanto, a superfície de um substrato nominal (cortado numa dada direção) nunca é completamente lisa, mas sim possui uma certa densidade de terraços que depende do erro realizado durante o corte (geralmente da ordem de $0,1^{\circ}$ ). Ao contrário, existem substratos desorientados (cortados intencionalmente com alguns graus de inclinação em relação a um dado plano) que possuirão uma alta densidade de terraços (um substrato (001) desorientado de 2 graus possui terraços de $81 \AA$ de largura). Este novo tipo de substrato está sendo muito utilizado ultimamente, pois a alta densidade de degraus 
possibilita a aparição de um novo tipo de crescimento que melhora bastante as propriedades estruturais e físicas das amostras.

Arthur foi o primeiro ${ }^{46,47}$ a estudar a cinética de incorporação na superfície (001) de GaAs, usando um sistema MBE com um espectrômetro de massa posicionado especificamente para analisar os elementos desadsorvidos (ou não) da superfície do substrato em função das

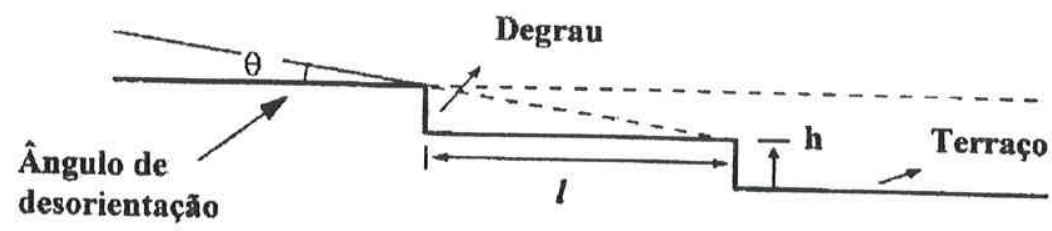

Figura II-3 - Esquema da superficie de um substrato desorientado de GaAs; $\theta$ è o ângulo de desorientação que origina uma densidade de terraços de largura l e altura h igual à distância entre duas monocamadas - a/2, na direção $[001]^{48}$.

condições de crescimento. Definiu os coeficientes de colagem $\beta_{\text {coll }}$, de desadsorção $\beta_{\text {des }}$ e de incorporação $\beta_{\text {incorp }}$, como sendo respectivamente a fração dos átomos incidentes que não são refletidos elasticamente pela superfície (i.e que são adsorvidos), a razão entre o número de átomos desadsorvidos e adsorvidos, e a razão do número de átomos efetivamente incorporados no cristal em relação ao número de átomos incidentes. Portanto, se $N_{\text {incid, }}, N_{\text {ads }}, N_{\text {des }}$ e $N_{\text {incorp }}$ são respectivamente o número de átomos incidentes, adsorvidos, desadsorvidos e incorporados, temos que

$$
\begin{gathered}
\beta_{c o l}=N_{\text {ads }} / N_{\text {incid }}, \\
\beta_{\text {des }}=N_{\text {des }} / N_{\text {ads }}, \\
\beta_{\text {incorp }}=N_{\text {incorp }} / N_{\text {incid }}=\left(N_{\text {ads }}-N_{\text {des }}\right) / N_{\text {incid }} .
\end{gathered}
$$

Arthur mostrou que o coeficiente de colagem (sticking coeficient) do gálio era unitário abaixo de $650^{\circ} \mathrm{C}$, com ou sem a presença de um fluxo de arsênio sobre a amostra. Acima desta temperatura, o gálio começava a ser revaporado. No caso de um fluxo de $\mathrm{As}_{2}$ ou $\mathrm{As}_{4}$, descobriu que o coeficiente de colagem era zero, a menos que a superfície estivesse populada com átomos de gálio ou que o substrato estivesse com temperatura superior a $450^{\circ} \mathrm{C}$, já que nestas condições 0 arsênio começa a ser evaporado da amostra, deixando portanto uma superfície rica em gálio. Mesmo com uma população de gálio suficiente na superfície para consumir todos os átomos 
incidentes, o fluxo de $\mathrm{As}_{4}$ possuía um coeficiente de colagem máximo de 0,5 , enquanto que o de $\mathrm{As}_{2}$ chegava a ser unitário. A conclusão de sua investigação era que um fluxo de arsênio incidindo sobre a amostra devia sempre estar presente para repor os átomos de arsênio evaporados pela alta temperatura do substrato, necessária para obter um crescimento de boa qualidade. $O$ excesso era então desadsorvido, já que sem a presença de átomos de gálio, o coeficiente de colagem era nulo. O crescimento podia ser iniciado pela emissão simultânea de um fluxo de átomos de gálio, já que este elemento era necessário para incorporar os átomos de arsênio e formar a camada cristalina de GaAs. Para evitar qualquer problema de estequiometria, o fluxo de arsênio devia sempre ser mais alto que o de gálio. Para levar em conta esta diferença de cinética do $\mathrm{As}_{2}$ e $\mathrm{As}_{4}$, Foxon e Joyce apresentaram o modelo seguinte ${ }^{49}$. No caso de $\mathrm{As}_{2}$, as moléculas eram adsorvidas (fisicamente) na superfície onde podiam migrar para encontrar dois átomos de gálio vizinhos. Ali, a molécula era dissociada e os dois átomos incorporados na rede cristalina. Dependendo da população superficial de gálio, as moléculas podiam ser desadsorvidas antes de serem incorporadas. No caso de um fluxo incidente de arsênio tetramérico, duas moléculas de $\mathrm{As}_{4}$ precisam interagir e serem dissociadas na superfície para que quatro átomos de arsênio possam ser incorporados. Os quatro outros átomos são desadsorvidos sob a forma de uma molécula $\mathrm{As}_{4}$, justificando o coeficiente de colagem máximo 0,5. Com estes dois mecanismos de incorporação, o fluxo de arsênio precisa ser, teoricamente, a metade do fluxo de gálio para que haja crescimento de um filme estequiométrico. Porém, para repor o arsênio evaporado durante o crescimento, razões de fluxo V/III entre 1 e 20 são geralmente empregadas, dependendo da temperatura de crescimento.

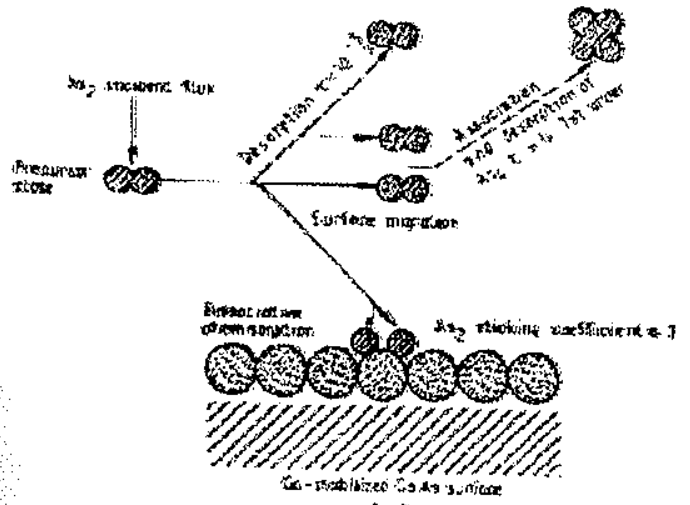

(a)

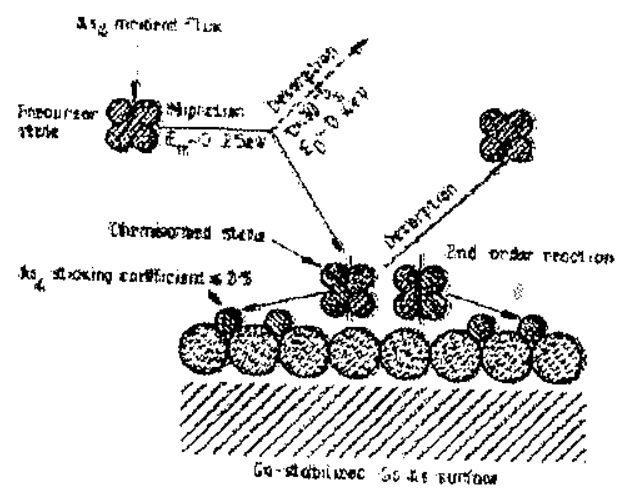

(b)

Figura II-4 - Modelos de incorporação das moléculas de (a)A $s_{2}$ e (b)As $s_{4}$ sobre uma superfície rica em gálio ${ }^{49}$.

Foi rapidamente evidenciado que os processos de superfície ocupavam um lugar muito importante, já que a qualidade final das amostras era muito dependente das condições de 
crescimento como a temperatura do substrato e a razão dos fluxos. Os fenômenos superficiais envolvidos são basicamente a adsorção, a difusão, a dissociação e a desadsorção que são governados por tempos característicos $\tau_{i}$. Como estes processos são geralmente ativados termicamente, eles são controlados por uma energia de ativação e podem ser determinados pela relação

$$
\tau=\tau_{0} \exp \left(E_{a} / k T\right)
$$

onde $\tau_{0}, E_{a}, k$ e $T$ são respectivamente um período característico de vibração (da ordem de $10^{-13} \mathrm{~s}$ ), a energia de ativação do processo, a constante de Boltzmann e a temperatura. A baixa temperatura, a adsorção é mais eficiente e a desadsorção mais fraca, mas a difusão superficial é mais limitada, o que acaba prejudicando a qualidade cristalina das camadas epitaxiais. A alta temperatura, a difusão é favorecida, mas a adsorção é prejudicada e a desadsorção é muito mais rápida, o que acaba prejudicando a estequiometria. Portanto, um compromisso precisa ser encontrado para que as propriedades do produto final sejam otimizadas.

A superfície do substrato nunca é atomicamente lisa, como no caso ideal, mas apresenta sempre uma certa densidade de defeitos, deslocações, impurezas e terraços que influenciam os processos superficiais. A incorporação será geralmente realizada em um destes sítios, já que eles propiciam uma variação menor da energia livre do sistema. Se a amostra for muito lisa, os átomos de gálio que controlam o crescimento poderão migrar mais facilmente sobre a superfície e encontrar o sítio mais adequado para serem incorporados, produzindo amostras de boa qualidade. Caso a topografia seja rugosa, os átomos serão incorporados imediatamente, deteriorando as características finais das camadas.

\section{II.2 - Sistema RHEED}

Para investigar e entender melhor a dinâmica do crescimento e os fenômenos microscópicos relacionados, precisa-se de um instrumento que seja sensível às mudanças estruturais da camada superficial do substrato. Neste sentido, o sistema RHEED é uma ferramenta única, pois possui uma configuração otimizada para fornecer dados em tempo real antes, durante e após o crescimento. Ele é constituído por um canhão de elétrons produzindo um feixe estreito e colimado $(0,5 \mathrm{~mm}$ de diâmetro) que incide com um ângulo rasante (geralmente da ordem de 1 grau) sobre a amostra localizada no centro da câmara de crescimento. O feixe é parcialmente refletido e difratado pela superfície do substrato e visualizado sobre uma tela fluorescente situada do lado oposto ao canhão (ver Figura I-4). Para entender corretamente seu 
funcionamento, algumas propriedades físicas dos cristais e da difração precisam ser lembradas.

Toda estrutura cristalina pertence a uma classe de rede de Bravais que pode ser definida como um conjunto infinito de pontos cujo arranjo e orientação são idênticos, qualquer que seja o ponto de vista dentro do cristal. Isto significa que a posição $\vec{R}$ de qualquer um destes pontos pode ser determinada como

$$
\vec{R}=n_{1} \vec{a}_{1}+n_{2} \vec{a}_{2}+n_{3} \vec{a}_{3}
$$

onde $\vec{a}_{1}, \vec{a}_{2}$ e $\ddot{a}_{3}$ são três vetores não planares, e $n_{l}, n_{2}$ e $n_{3}$ são inteiros. Para estudar o fenômeno de difração, é muito cômodo trabalhar no espaço de Fourier, também chamado de espaço $k$ ou reciproco. Se considerarmos uma rede de Bravais com seu conjunto de vetores $\vec{R}$ e uma onda plana $e^{i \vec{k} \cdot \vec{r}}$, em geral esta onda não terá a periodicidade da rede. Todavia, para alguns vetores $\vec{K}$, a periodicidade será respeitada, e neste caso $e^{i \ddot{K} \cdot(\ddot{R}+\ddot{r})}=e^{i \ddot{k} \cdot \ddot{r}}$ o que implica que

$$
e^{i \hat{K} \cdot \vec{R}}=1
$$

A rede recíproca (da rede de Bravais constituída pelos vetores $\vec{R}$ ) será formada por todos os vetores $\vec{K}$ satisfazendo esta relação para qualquer valor de $\vec{r}$ e todos os vetores $\vec{R}$ da rede original de Bravais. A rede recíproca é também uma rede de Bravais, sendo que se os vetores primitivos (que definem a menor célula unitária capaz de preencher completamente a rede de Bravais por simples translação) da rede direta (no espaço real) são $\vec{a}_{1}, \vec{a}_{2}$ e $\vec{a}_{3}$, os vetores primitivos da rede recíproca são dados por ${ }^{50}$

$$
\begin{aligned}
& \vec{b}_{1}=2 \pi \frac{\vec{a}_{2} \times \vec{a}_{3}}{\vec{a}_{1} \cdot\left(\vec{a}_{2} \times \vec{a}_{3}\right)}, \\
& \vec{b}_{2}=2 \pi \frac{\vec{a}_{3} \times \vec{a}_{1}}{\vec{a}_{1} \cdot\left(\vec{a}_{2} \times \vec{a}_{3}\right)}, \\
& \vec{b}_{3}=2 \pi \frac{\vec{a}_{1} \times \vec{a}_{2}}{\vec{a}_{1} \cdot\left(\vec{a}_{2} \times \vec{a}_{3}\right)},
\end{aligned}
$$

onde os vetores $\vec{a}_{i}$ e $\vec{b}_{j}$ são tais que $\vec{a}_{i} \cdot \vec{b}_{j}=2 \pi \delta_{i j}$, onde $\delta_{i j}$ é o símbolo de Kronecker que vale 1 quando $i=j$, e vale 0 quando $i \neq j$.

Em 1913, Bragg descobriu que cristais podiam produzir padrões de difração muito especificos quando eram bombardeados por raios X. Explicou esta propriedade simplesmente pela reflexão dos raios sobre os planos formados por átomos pertencentes a diferentes camadas, que podiam, em algumas condições, interferir construtivamente. Para obterem-se regiões com traximos e mínimos de intensidade, uma interferência é necessária, o que significa que a 

levando à relação

$$
2 d \operatorname{sen} \theta=m \lambda
$$

onde $d$ é a distância entre dois planos, $\theta$ é o ângulo de incidência do feixe em relação aos planos considerados, $m$ é um inteiro e $\lambda$ é o comprimento de onda da radiação empregada.

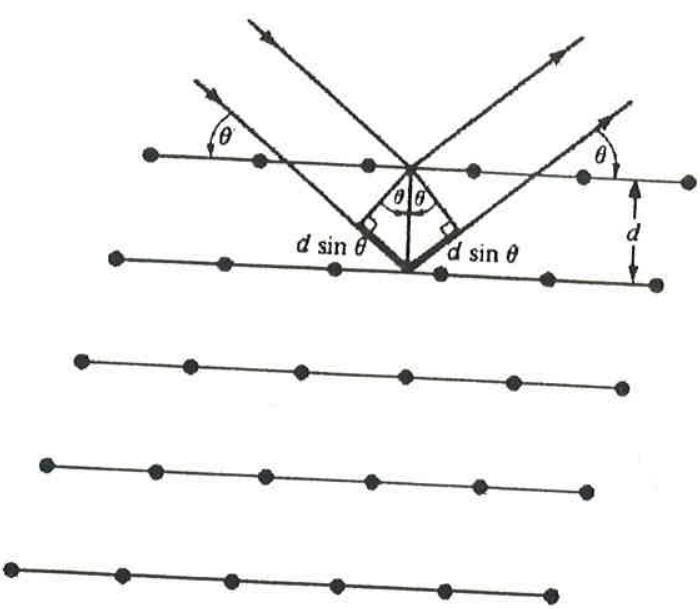

Figura II-5 - Reflexão de Bragg de uma familia particular de planos da rede separados por uma distância d; os raios incidentes e refletidos são mostrados para os dois planos vizinhos; a diferença de caminho é $2 d \operatorname{sen} \theta$.

Uma outra visão da difração foi introduzida por von Laue e é mais adequada para a interpretação dos dados do sistema RHEED. Neste caso, considera-se que o cristal seja composto por centros espalhadores idênticos (por exemplo átomos), localizados nos sítios de uma rede de Bravais, que possam refletir a radiação incidente em todas as direções. Para obterse uma interferência construtiva, considerem-se dois centros espalhadores, separados por um vetor $\vec{d}$, sobre os quais incide uma radiação de comprimento de onda $\lambda$, i.e. determinada por um vetor $\vec{k}=(2 \pi / \lambda) \vec{n}$ onde $\vec{k}$ é o vetor de onda da radiação incidente e $\vec{n}$ é um vetor unitário apontando na mesma direção (Figura II-6). A radiação é espalhada na direção $\vec{n}^{\prime}$, sendo que o módulo do vetor de onda $\vec{k}^{\prime}$ é o mesmo que o da radiação incidente, já que o espalhamento é principalmente elástico. Há portanto conservação da energia total $E=h c / \lambda$, onde $h$ é a constante de Planck e $c$ a velocidade da luz, o que implica na conservação do módulo de $\vec{k}$. Para satisfazer a condição de interferência construtiva, precisa-se que

$$
d \cos \theta+d \cos \theta^{\prime}=m \lambda,
$$

que pode também ser escrito 


$$
\vec{d} \cdot\left(\vec{n}-\vec{n}^{\prime}\right)=m \lambda
$$

e, multiplicando os dois lados de (II-11) por $2 \pi / \lambda$

$$
\vec{d} \cdot(\vec{k}-\vec{k})=2 m \pi \text {. }
$$

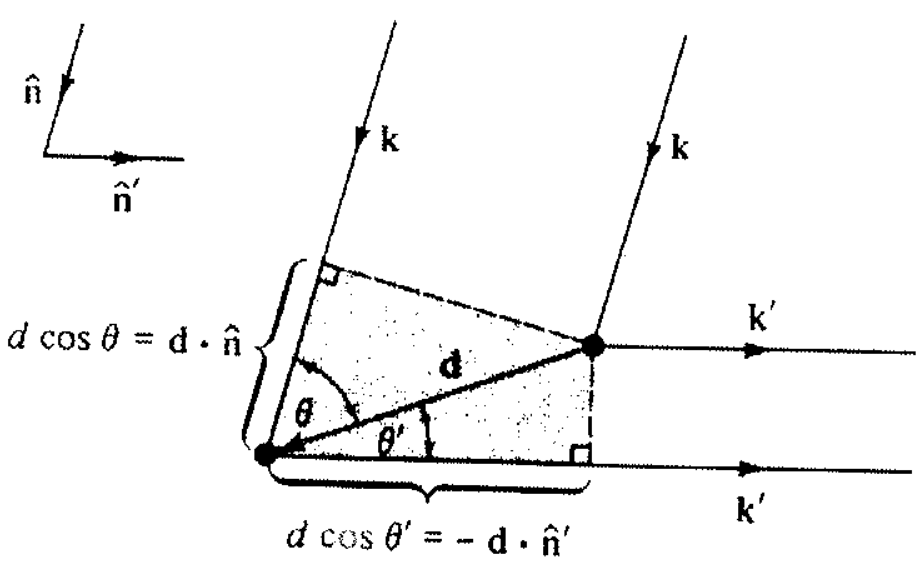
Figura II-6 - Modelo de von Laue, ilustrando a diferença de caminho para os raios espalhados por dois pontos
separados por uma distancia d.

Como os centros espalhadores pertencem a uma rede de Bravais, o vetor $\vec{d}$ pode ser substituído por um vetor $\vec{R}$ qualquer da rede de Bravais e podemos escrever ( II-12) como

$$
e^{i\left(\vec{k}-\vec{k}^{\prime}\right) \cdot \vec{k}}=1
$$

Comparando esta relação com a definição da rede recíproca eq. ( II-7), chega-se à conclusão que haverá interferência construtiva toda vez que a diferença entre o vetor de onda inicial e final

$$
\vec{K}=\vec{k}-\vec{k}
$$

for um vetor da rede recíproca. Ewald propôs uma construção geométrica muito útil para visualizar a condição de von Laue e interpretar os resultados experimentais. Trata-se de desenhar, no espaço recíproco, uma esfera de raio $k$, sendo que o centro da esfera é ocupado pela extremidade do vetor $\vec{k}$ cuja origem está sobre um ponto da rede pelo qual passa a esfera (aqui, por simplicidade, escolhemos uma rede de Bravais bidimensional e um círculo, o que pode ser considerado como a projeção do caso tridimensional sobre um dos planos da rede). Haverá difração na direção $\vec{k}$ toda vez que o vetor $\vec{K}$, que varre toda a superfície da esfera, encontrar um ponto da rede de Bravais, satisfazendo assim a condição de von Laue. 
No caso de um sistema RHEED, o feixe de elétrons possui uma energia cinética devida à alta voltagem de aceleração presente no canhão, o que implica num valor de $\lambda$ dado em boa aproximação por ${ }^{51}$

$$
\lambda \approx \sqrt{\frac{150}{V\left(1+10^{-6} V\right)}}[\AA]
$$

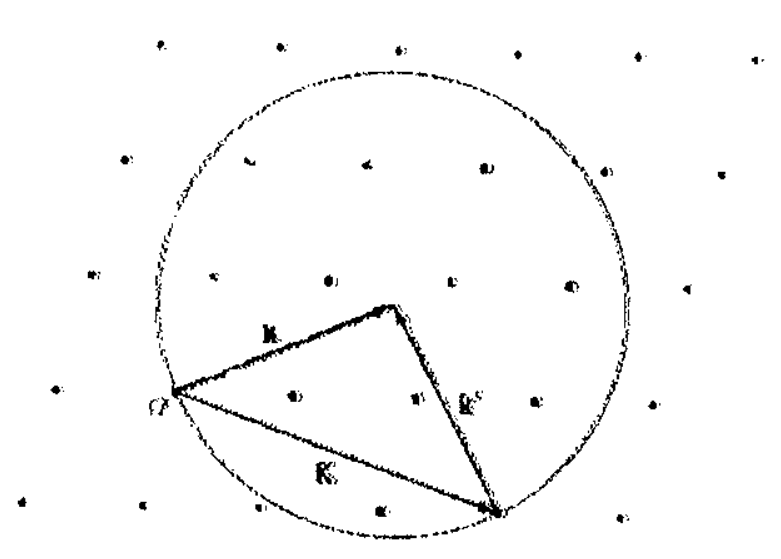

Figura II-7 - Esfera de Ewald no espaço recíproco bidimensional; $\vec{k}$ é o vetor de onda incidente, $\vec{k}^{\prime} \dot{e}$ o vetor difratado e $\vec{K}$ é o vetor da rede reciproca que satisfaz a relação (II-14).

Para uma voltagem de $8 \mathrm{kV}$ (usado em nosso sistema), obtemos $\lambda=0,1364 \AA$. Conseqüentemente, o raio da esfera de Ewald, no espaço recíproco, será de $46,07 \AA^{-1}$. Como o parâmetro de rede da célula unitária do GaAs é $a=5,6533 \AA$ e o espaço recíproco de uma rede de Bravais cúbica (de lado $a$ ) com faces centradas é uma rede de Bravais cúbica (de lado $2 \pi / a$ ) de corpo centrado ${ }^{52}$, a distância entre dois pontos da rede recíproca será de $1,11 \AA^{-1}$. Todavia, devido à incidência rasante do feixe, os elétrons penetram unicamente nas primeiras camadas superficiais do substrato. A penetração do feixe na amostra é uma função da componente vertical do momento (perpendicularmente à superfície), que para um feixe de $8 \mathrm{keV}$ com incidência de 1 grau representa um valor da ordem de $140 \mathrm{eV}$ e portanto um poder de penetração de uma a duas camadas. Assim sendo, o sistema RHEED sonda uma rede cristalina bidimensional, onde a terceira dimensão está faltando, cujo espaço recíproco possuirá uma terceira dimensão indefinida. A conseqüência é que, na construção de Ewald, a relação de difração precisa ser respeitada no plano recíproco unicamente, e não no espaço inteiro. Este levantamento de uma das condições de difração (relacionada com a terceira dimensão do espaço) provoca uma degenerescência das soluções possíveis, já que qualquer vetor $\vec{k}^{\prime}$, cuja 
projeção no plano satisfizer o critério de Laue (na geometria de Ewald), será uma direção de difração possível. Uma visualização fácil e intuitiva deste fenômeno pode ser representada imaginando-se o plano recíproco atravessado, em cada ponto da rede de Bravais, por uma linha vertical (correspondendo à degenerescência). O conjunto completo de direções possíveis de difração será dado pela interseção destes bastões (chamados rods) com a esfera de Ewald. Devido ao grande raio de curvatura da esfera em relação à distância entre dois pontos da rede reciproca, obteremos linhas de interseção em vez de pontos. Portanto o padrão de difração de um filme de GaAs cristalino atomicamente liso apresentará linhas brilhantes alternadas com regiões mais escuras. Estas linhas possuem uma largura finita (não nula), pois tanto a esfera de Ewald quanto os bastões apresentam uma certa espessura provocada pela largura do espectro energético dos elétrons (no caso da esfera) e pela presença de defeitos estruturais da rede e do espalhamento por fônons. Como só uma parte do feixe incidente é difratado, existirá um ponto brilhante, localizado no centro de padrão de difração, devido ao feixe especular, refletido diretamente pela superficie do filme.

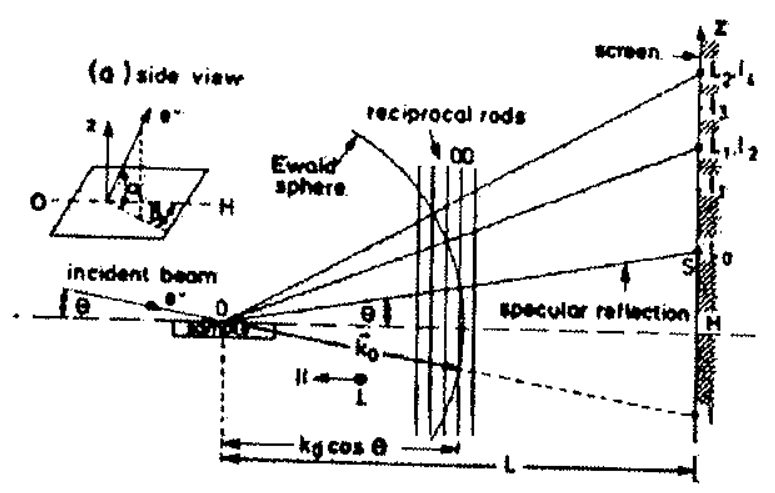

(a)

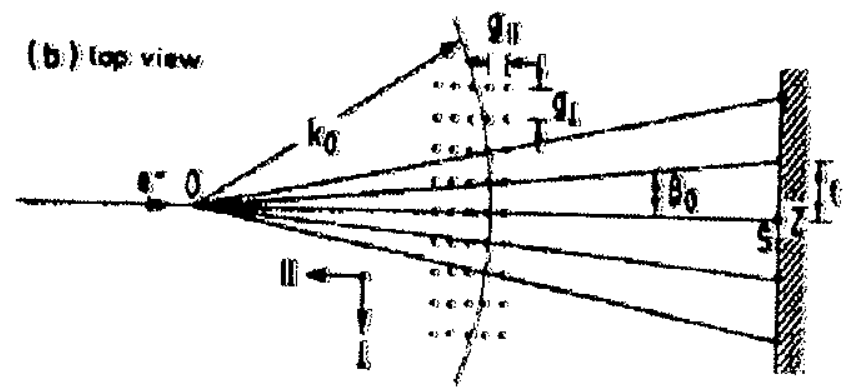

(b)

Figura Il-8 - a) Espaço reciproco de uma rede de Bravais bidimensional, mostrando as soluções da equação de von Laue (visto de lado); os bastões passando por cada ponto da rede; a interseção deste bastões com a esfera de semelhança de triângulos podemos determinar a tela fluorescente; b) mesmo fenômeno, mas visto de cima; por semethança de triângulos podemos determinar diretamente o parâmetro de rede na tela ${ }^{53}$.

Conhecendo a configuração geométrica do sistema RHEED, pode-se determinar o parâmetro de rede do fílme sendo crescido. Considerando o triângulo determinado pelo raio $k_{0}$ da esfera de Ewald $(2 \pi / \lambda)$ e pela distância $g_{\perp}$ entre dois pontos da rede recíproca $(2 \pi / a)$, e o triângulo semelhante determinado pela distância $t$ entre duas linhas do padrão de difração e pela distância $L$ entre a amostra e a tela fluorescente, pode-se escrever que $g_{\perp} /(2 \pi / \lambda)=t / L$, ou ainda

$$
\lambda / a=t / L \text {. }
$$


Temos então que

$$
a=\lambda I / t
$$

onde agora todas as variáveis são conhecidas.

Quando a superfície da amostra é rugosa (Figura II-9), o feixe atravessa as protuberâncias presentes sobre o filme, e a difração é então tridimensional, produzindo um padrão de pontos (Figura II-10a) relacionados com a interseção da esfera de Ewald com a rede de Bravais do espaço recíproco. Apesar do feixe de elétrons possuir um tamanho da ordem de $0,5 \mathrm{~mm}$ de

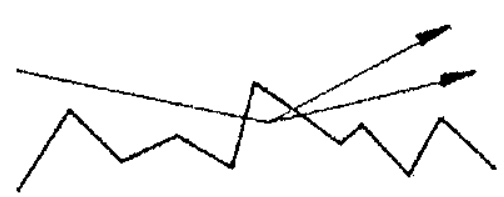

(a)

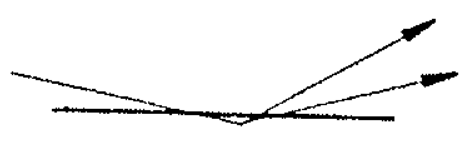

(b)

Figura II-9 - (a)transmissão, reflexão e difração em superficies rugosas; (b)reflexão e difração em uma superficie
atomicamente lisa.

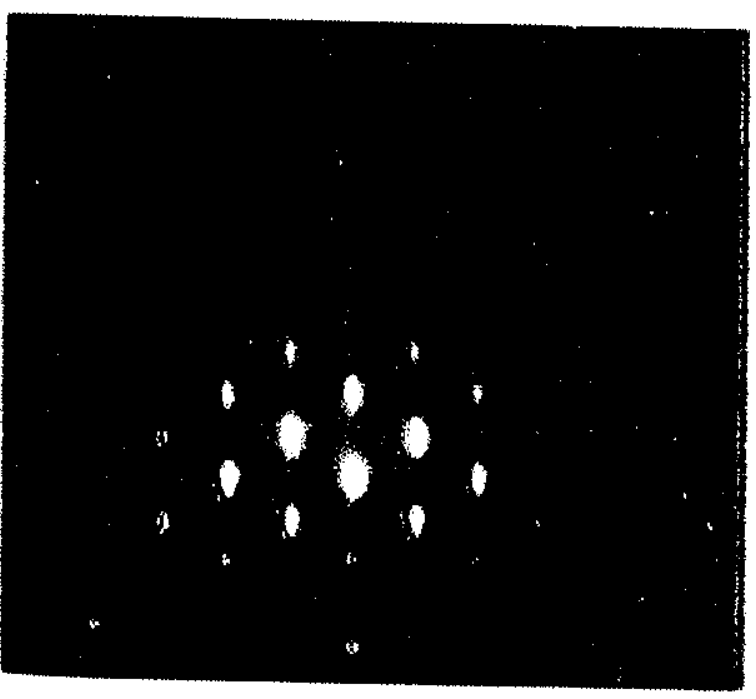

(a)

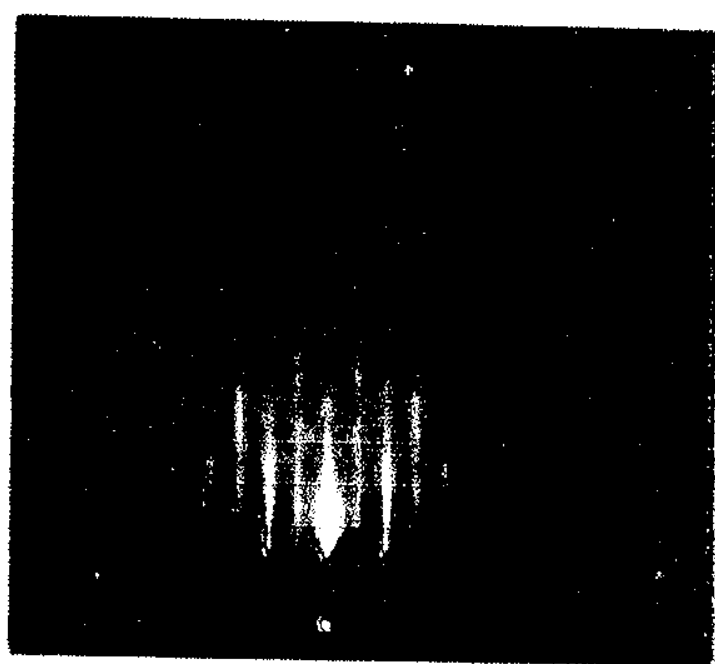

(b)

Figura II-10 - Padrão de difração observado na tela fluorescente quando (a)a amostra é rugosa, ę(b)quando é lisa.

diâmetro, a superfície da amostra que causa a difração se estende numa área de $0,5 \mathrm{~mm}$ de largura por $20 \mathrm{~mm}$ de comprimento, devido ao baixo ângulo de incidência ${ }^{54}$. Uma outra consequiência da geometria do sistema RHEED é que o padrão de difração é unicamente relacionado com a periodicidade da rede cristalina na direção perpendicular à direção do feixe. Portanto, para investigar a estrutura completa do material, precisa-se girar a amostra. É uma das razões pela qual o forno da câmara de crescimento possui um sistema motorizado possibilitando 
a rotação da amostra de qualquer ângulo com boa precisão.

Antes da desoxidação do substrato na câmara de crescimento, o padrão de difração é difuso em razão da estrutura amorfa do filme de óxido presente na superficie. Em torno de $580^{\circ} \mathrm{C}$, e na presença de um fluxo de arsênio para repor o arsênio que está sendo evaporado da amostra devido a alta temperatura, o óxido é desadsorvido, revelando a estrutura cristalina do substrato. Geralmente, neste estágio, o padrão de difração não é constituído por linhas, mas sim por pontos, por causa da rugosidade natural da superficie provocada pela limpeza química. Todavia, após o crescimento de uma centena de camadas de GaAs, o padrão linear aparece, indicando um alisamento da superfície a nível atômico (Figura II-10b). Cho ${ }^{55}$ foi o primeiro a observar que a distância entre as linhas do padrão de difração levava a um parâmetro de rede do GaAs duas vezes maior do que se esperava. De fato, o padrão apresentado pela amostra era uma seqüência de linhas fracas com linhas mais brilhantes, sendo que as mais brilhantes forneciam o parâmetro certo, e as mais fracas o dobro. Este fenômeno é provocado pelo fato que a superfície de uma amostra cristalina apresenta raramente a mesma estrutura que o material maciço pelo fato dos átomos superficiais possuírem um número diferente de vizinhos. Algumas ligações foram cortadas e ficaram incompletas (os dangling bonds), tornando a superficie metálica e aumentando consideravelmente sua energia livre. Neste caso, as ligações pendentes possuem uma tendência a se rearranjar, e vacâncias assim como dimeros podem ser criados para diminuir a energia total e deixar a superfície numa configuração mais estável. Este fenômeno de reconstrução de superfície não deve ser confundido com o fenômeno de relaxação da superfície, onde a simetria do material maciço é conservada, mas o parâmetro de rede é diferente. A relaxação é comum em superficies não polares, enquanto que a reconstrução é típica de superfícies polares, como é o caso do plano $(001)^{56}$.

Numa superfície não polar, a presença de ligações não saturadas (incompletas) é resolvida pela transferência parcial de carga dos cátions para os ânions, já que por definição eles estão presentes em mesmo número e a carga de um é complementar da carga do outro. Esta transferência esvazia as ligações pendentes dos cátions e preenche completamente as dos ânions, providenciando assim uma superfície semicondutora com a presença de um gap entre os estados vazios e ocupados.

Numa superfície polar do tipo (001), a última camada é constituída por átomos de uma linica espécie, e a compensação das ligações não pode ser resolvida por simples transferência de carga como no caso anterior. Um rearranjo mais complexo, envolvendo a dimerização (criação de uma ligação ente dois átomos de mesma espécie) e a remoção de uma parte dos átomos 
(criando vacâncias), é necessário para expor a segunda camada e criar um ambiente não polar possibilitando a transferência de carga entre as duas camadas de espécies diferentes. Este rearranjo modifica a célula unitária superficial e sua simetria. Devido à configuração tetraédrica das ligações na estrutura zincblende, a dimerização ocorre na direção das ligações pendentes superficiais e provoca uma reconstrução do tipo $2 \times N$, já que a distância entre os átomos ligados diminui, aumentando o tamanho da nova célula unitária. Numa superfície (001), a criação de

(a)

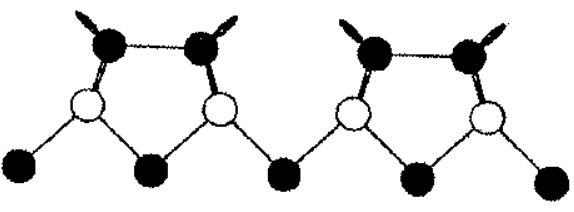

(b)

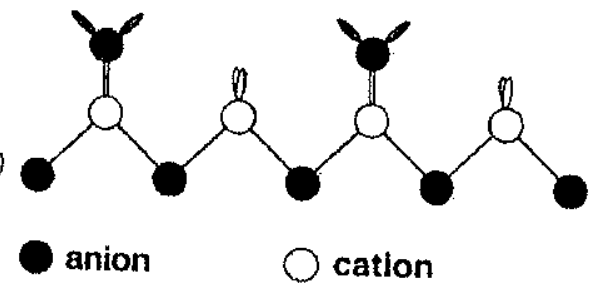

Figura II-11 - Projeção no plano (110) de uma superficie de GaAs (001) reconstruida e terminada com ânions. Em (a) a reconstrução é realizada por dimerização. Em (b) há criação de vacâncias na camada superficial. As ligações pendentes dos ânions estão completamente preenchidas (em preto) e as dos cátions vazias (em branco) ${ }^{\text {s6. }}$.

uma vacância expõe dois átomos da camada inferior e cria duas novas ligações pendentes. Conhecendo a população dos átomos de cada espécie na superfície, é possível prever quais são as reconstruções que podem ocorrer. Esta previsão se baseia sobre o fato que, no equilíbrio, a superfície tende a apresentar um caráter semicondutor, preenchendo todas as ligações pendentes do elemento mais eletronegativo e esvaziando as orbitais do outro. Portanto, para que isto seja possivel, a regra de contagem dos elétrons ${ }^{57,58}$ é aplicada, que estipula que, na célula unitária nova, o número total de elétrons disponiveis nas ligações pendentes dos cátions deve ser igual ao número total de estados vazios nas ligações pendentes dos ânions, levando à compensação eletrônica da superfície após a reconstrução.

No GaAs, cada ânion (os átomos de arsênio) é ligado a quatro cátions (os átomos de gálio), e cada um contribui na média com $5 / 4$ e $3 / 4$ elétrons em cada ligação (pois pertencem respectivamente à família V e III). Supondo a superficie do plano (001) coberta completamente por átomos de arsênio formando dímeros, cada um deles contribuiria com $5 / 4$ elétrons para as duas ligações com a camada inferior e 1 elétron para a ligação dimérica. Portanto, sobrariam 5. $\{(5 / 4) \times 27-1\}=1,5$ elétrons para cada ligação pendente. Esta situação metálica é instável, o 
que inviabiliza este tipo de reconstrução $2 \times 1$. Todavia, removendo dímeros da camada superficial, cada vacância de um dímero criaria quatro ligações pendentes nos dois cátions da camada inferior, possibilitando uma transferência de carga. O número de vacâncias não pode ser escolhido aleatoriamente, pois precisa compensar a carga total superficial. Supondo que a reconstrução final possua $D$ dímeros e $N-D$ dímeros faltando numa célula unitária do tipo $2 \times \mathrm{N}$, $(N-D) \times+\times(3+t)=3(N-D)$ elétrons tornam-se disponíveis nas ligações pendentes da segunda camada para a transferência de carga ( $3 / 4$ elétron por ligação). O preenchimento de uma ligação

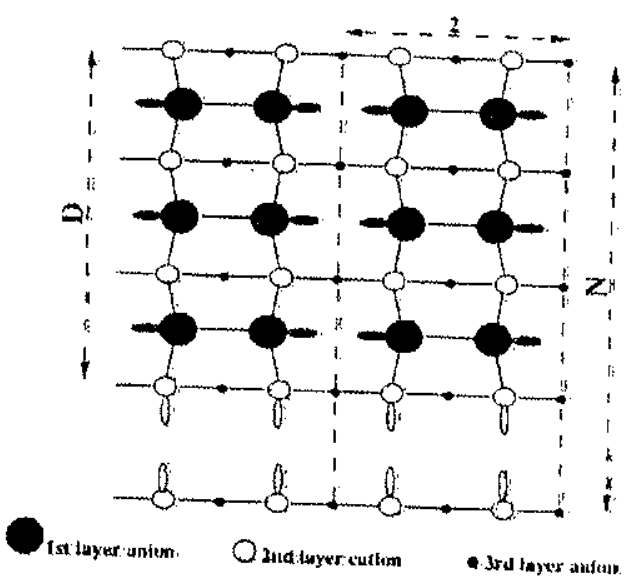

(x):

Figura II-12 - Visão esquemática superior de uma superficie reconstruida terminada com ânions, exibindo uma estrutura $2 \times N$ com $D$ ânions diméricos na camada superior e $4 \times(N-D)$ cátions expostos na segunda camada; as ligações pendentes dos ânions (preenchidas) e ligaçoes pendentes vazias dos cátions são também representadas ${ }^{\text {so }}$.

pendente de cada dímero de arsênio necessita $1 / 2$ elétron, o que significa que para a célula unitária, precisam-se de $(1 / 2) \times 2 \times D=D$ elétrons. Assim sendo, o balanço das cargas superficiais deve respeitar a equação $3(N-D)=D$ ou $4 D=3 N$. A solução é $N=4$ e $D=3$, o que significa que a superfície possui uma reconstrução $2 \times 4$ formada por uma série de 3 dímeros de arsênio alternados com uma vacância. Esta reconstrução foi proposta por Farell ${ }^{59}$ para explicar o padrão de difração observado na tela do sistema RHEED para uma superfície rica em arsênio. Quando o feixe de elétrons estava incidindo nas direções [110] e [1 10], o tamanho da célula unitária superficial era multiplicada por 2 e 4 respectivamente (i.e. apareciam linhas de difração de ordem $1 / 2$ e $1 / 4$ entre as linhas principais ligadas à estrutura cristalina do material maciço). Outras configurações levando à mesma simetria $2 \times 4$ satisfazem também a regra de contagem dos elétrons. Elas envolvem por exemplo dois dímeros de arsênio na camada superficial e dois dimeros de gálio na camada inferior, ou ainda dois dímeros de arsênio na camada superficial e umin terceiro dímero de arsênio na terceira camada. Até pouco tempo atrás, a simetria $2 \times 4$ era 
unanimemente atribuída à configuração com três dímeros. Todavia, graças à disponibilidade recente de novas técnicas de investigação a nível atômico (a técnica de microscopia de tunelamento e de força atômica) e de novos cálculos de energia livre, vários grupos propuseram como configuração estas duas últimas que possuem uma energia livre menor.

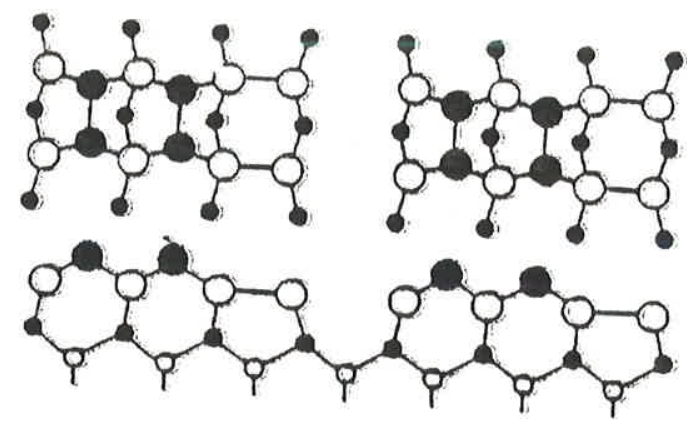

$\alpha-(2 \times 4)$

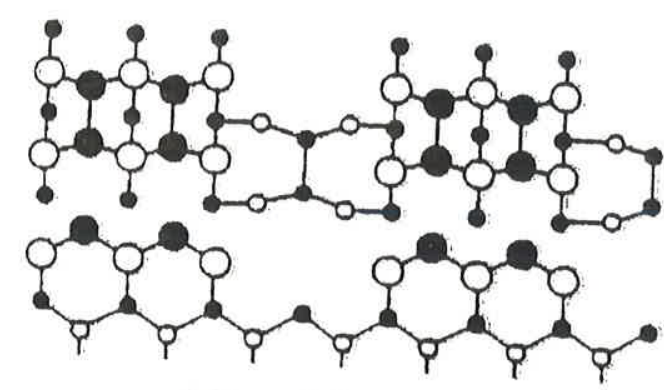

(d) $\beta 2-(2 \times 4)$

(b)

Figura II-13 - Outras configurações atômicas satisfazendo a regra de contagem dos elétrons para a reconstrução camada. A estrutura $\beta 2-(2 \times 4)$ possui dos dimeros de arsênio na superfície e dois dímeros de gálio na segunda na terceira camada.

A superfície (001) oferece na verdade uma grande variedade de reconstruções que dependem da população relativa das duas espécies. São estas as reconstruções $c(4 \times 4),(2 \times 4)$ ou $\mathrm{c}(2 \times 8),(4 \times 2)$ ou $\mathrm{c}(8 \times 2)$ e $(4 \times 6)$ por ordem decrescente da ocupação superficial por átomos de arsênio. As duas primeiras possuem uma superfície rica em arsênio com $150 \%$ e $75 \%$ de ocupação enquanto que as duas últimas são ricas em gálio. As duas outras reconstruções $(2 \times 4)$ mencionadas correspondem a $50 \%$ de átomos de arsênio na última camada. Para evitar possíveis confusões na definição da simetria de reconstrução, a notação de Wood é geralmente utilizada, onde a expressão GaAs (001) $\mathrm{c}(\mathrm{N} \times \mathrm{M})$ significa que o plano (001) do cristal de GaAs é reconstruído e possui uma célula unitária $(\mathrm{N} \times \mathrm{M})$ vezes maior que a estrutura cristalina subjacente do material maciço. A letra c menciona que o novo motivo superficial é centrado. Vale ressaltar que o sistema RHEED não consegue distinguir as duas estruturas do tipo $(2 \times 4) \mathrm{e}$ $c(2 \times 8)$, já que a nível microscópico elas são idênticas, a única diferença sendo o deslocamento de um dos motivos em relação a seus vizinhos. Portanto, a maioria dos resultados experimentais vale geralmente para os dois tipos de reconstrução. No caso de estudos RHEED do plano (001) de uma estrutura do tipo zincblende, a convenção é determinar os índices da reconstrução nas direções [1 10] e [110] correspondendo à direção das ligações covalentes. Portanto, para observar-se a reconstrução $(2 \times 4)$ pelo sistema RHEED, precisa-se orientar o feixe de elétrons na 
direção [110] para observarem-se as linhas de difração de ordem $1 / 2$ (já que o sistema RHEED determina unicamente a periodicidade da rede perpendicularmente à direção do feixe), e em seguida na direção [1 T0] para obterem-se as linhas de difração de ordem 1/4. Dentro de todas as reconstruções possíveis, foi evidenciado que só a reconstrução $(2 \times 4)$ fornecia camadas epitaxiais cristalinas e atomicamente lisas possuindo excelentes propriedades eletronicas e ópticas.

Como mostramos, a grande sensibilidade superficial do sistema RHEED vem da baixa incidência do feixe e da alta energia dos elétrons que providenciam um padrão de difração de alta qualidade. No início, esta informação era unicamente destinada a investigar a orientação do cristal dentro da câmara de crescimento e analisar as possíveis reconstruções de superfície obtidas pela mudança das condições de crescimento. Com o melhoramento progressivo das condições de crescimento, detectou-se que algumas partes do padrão oscilavam durante o crescimento e ofereciam outras informações úteis. Precisou-se então de um sistema de detecção da intensidade luminosa do padrão que, acoplado a um computador, pudesse monitorar qualquer variação dinâmica de sinal. Apareceram nesta época os primeiros sistemas de fibra óptica acoplados a uma fotomultiplicadora que convertia o sinal luminoso em sinal elétrico que podia ser lido pelo computador pela mediação de uma placa de aquisição de dados. Mais tarde, observou-se que a presença de terraços, defeitos cristalinos ou anisotropia do crescimento podiam ser detectados também pela forma e largura das linhas de difração. Além disso, o crescimento in situ de estruturas de baixa dimensionalidade, tais como fios e pontos quânticos, necessitava a investigação do padrão inteiro, o que não podia ser realizado com uma simples fibra óptica localizada num único ponto do padrão. Hoje em dia, os sistemas RHEED modernos são equipados com um canhão de elétrons, fornecendo um feixe de até $50 \mathrm{keV}$, e uma câmera CCD (charged coupled devices), conectada a um computador, permitindo a visualização e gravação do padrão inteiro. Programas computacionais de tratamento de dados e imagens possibilitam a monitorização em tempo real da intensidade de várias regiões simultaneamente, assim como o estudo do perfil das linhas. O sistema RHEED tornou-se a ferramenta mais poderosa para o estudo in situ do crescimento $\mathrm{MBE}$, e é agora indispensável tanto para a caraterização básica das condições de crescimento quanto para a investigação dos mecanismos nicroscópicos superficiais.

\section{3 - Dinâmica do crescimento}

Foi só em 1981 (onze anos depois da introdução do primeiro sistema RHEED numa camara MBE) que Harris e Joyce ${ }^{60,61}$ detectaram pela primeira vez que a intensidade luminosa 
especular oscilava com uma certa freqüência durante o crescimento, e que com o tempo, a amplitude ia diminuindo. A frequeência era proporcional ao fluxo dos elementos da família III, e medidas de espessura dos filmes crescidos confirmaram rapidamente que seu período coincidia exatamente com o tempo necessário para crescer uma monocamada de GaAs. Um modelo dinâmico de crescimento foi proposto para explicar o comportamento oscilatório observado. Na superfície de um substrato liso rico em arsênio, sabe-se que o crescimento é controlado pela difusão e incorporação dos átomos da família III. No caso do GaAs, os átomos de gálio serão incorporados preferencialmente em sítios da rede que minimizam a energia livre superficial, i.e. em defeitos pontuais do tipo vacância ou impureza, ou em linhas de deslocações e bordas de terraços. A alta qualidade de fabricação dos substratos atuais diminuiu consideravelmente a densidade de defeitos pontuais (da ordem de $10^{8} \mathrm{~cm}^{-2}$ ), eliminou completamente as linhas de deslocações nos substratos, enquanto que o corte dos substratos no plano (001) pode ser realizado com uma precisão superior a 0,1 grau, gerando assim degraus monoatômicos a cada $1600 \AA$ ou mais (i.e. uma densidade inferior a $6 \times 10^{4} \mathrm{~cm}^{-2}$ ). Nestas condições, durante a difusão na superfície do substrato, os átomos de gálio possuirão uma maior probabilidade de serem incorporados em sítios pontuais, já que o comprimento de difusão é ativado termicamente e que nas condições usais de crescimento o valor deste parâmetro ${ }^{62}$ é da ordem de $50 \AA$ a $200 \AA$. Após a abertura da célula de gálio, a superfície, inicialmente lisa a nível atômico, será coberta por numerosos centros de nucleação compostos por um (ou vários) átomo de gálio. Como o crescimento de um semicondutor sobre um outro semicondutor procede no modo bidimensional (Franck-van der Merwe), os novos átomos chegando na superfície vão difundir no mesmo plano superficial, mas desta vez encontrarão os centros de nucleação onde serão incorporados, formando ilhas bidimensionais. As bordas das ilhas são sítios privilegiados de incorporação, pois, como no caso das bordas dos terraços, minimizam a energia livre da superfície. Portanto, os átomos incidentes de gálio difundem principalmente até as bordas des ilhas onde serão incorporados. Quando vários átomos de gálio formam uma ilha, ela vai sendo coberta pelos átomos de arsênio, já que seu coeficiente de colagem não é mais nulo na presença de uma população de átomos da família III. Todavia, por razões energéticas, nenhum crescimento é iniciado sobre as ilhas antes que a camada inferior seja completa ${ }^{56}$. Com esta interpretação do mecanismo de crescimento bidiunensional, do feixe especular podemariaçõ da intensidade luminosa atomicar explicadas da seguinte maneira: inicialmente, a superfície é crescimento, os e feixe especular possui seu máximo de intensidade. Após o início do . 
da radiação incidente e diminui a refletividade da superfície (a desordem é maior). Quando a metade da primeira camada foi crescida, ilhas bidimensionais ocupam a metade da superfície, e a refletividade é mínima (a desordem é máxima). Além deste ponto, a camada é quase completa e volta a aumentar sua refletividade (a ordem voltou parcialmente). Quando a camada foi completada, a refletividade é máxima novamente e termina o primeiro período da oscilação. Este processo se repete enquanto átomos de gálio e arsênio estiverem incidindo sobre a amostra, o que resulta em outras oscilações.

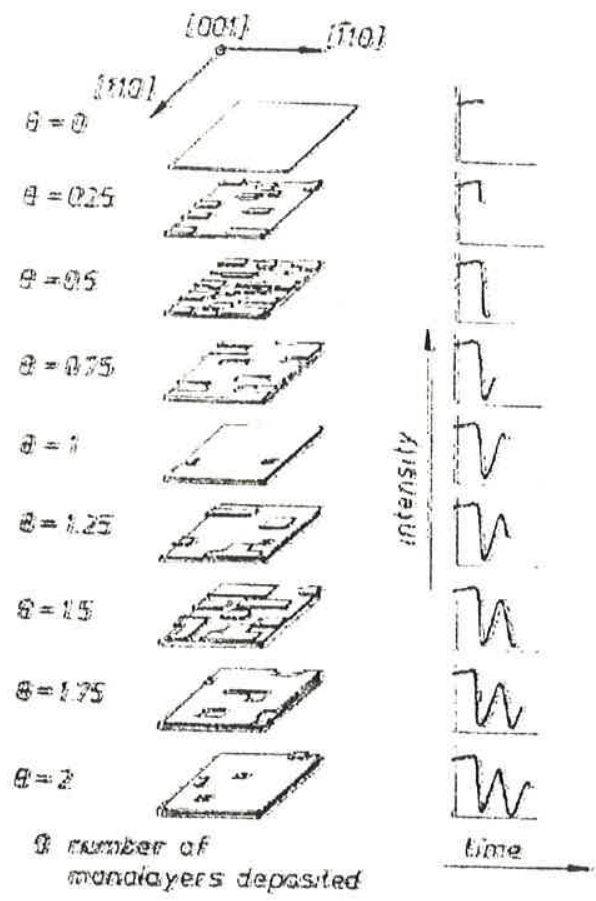

Figura II-1t - Representação da formação das duas primeiras monocamadas completas de GaAs na direção [001] e a correspondente observação através do sistema RHEED $^{63} ; \theta$ representa o número de monocamadas depositadas; a incidência dos elétrons está na direção [110]; note que as ilhas são mais alongadas na direção $[-110]$.

A diminuição progressiva da intensidade das oscilações pode ser explicada pelo fato do crescimento ser um processo dinâmico no qual a nucleação da segunda camada pode iniciar antes que a primeira esteja completa. Isto pode ocorrer de fato sobre as ilhas de grande tamanho, desde o momento que elas estejam completas. Nestas condições, a difusão não é suficiente para alcançar as bordas, e existe um processo de nucleação em cima da ilha, anteś que a camada inferior esteja preenchida. Esta segunda camada diminui a refletividade total da superfície antes mesmo que ela chegue a seu máximo. Portanto, acredita-se que, com o tempo, a frente do crescimento se torne mais rugosa, já que após um certo número de camadas, as mais superficiais serão incompletas. Quando o crescimento é terminado, a intensidade do feixe especular volta a seu valor máximo, mostrando que ocorre um alisamento da superfície ${ }^{64,65,66}$. Isto é realizado em duas etapas: o primeiro passo, que é muito rápido, é a incorporação, nas bordas das ilhas, dos 
últimos átomos ainda em processo de difusão. A segunda fase é mais demorada, pois consiste no rearranjo das pequenas ilhas cuja configuração é instável devido a seu tamanho. Como essas ilhas não alcançaram um certo tamanho critico, a energia livre de cada uma é muito grande ${ }^{67,68,69}$ e pode ser minimizada se elas migrarem e se juntarem com outras ilhas, formando identidades maiores e mais estáveis. Como este processo é acompanhado por uma transferência local de massa, ele é muito mais demorado, além de possuir uma energia de ativaçăo maior que a simples difusão de um átomo de gálio como é o caso no fenômeno anterior.

$O$ estudo do perfil de intensidade das linhas de difração segundo as direções [110] e [1 10$]$ mostrou uma perda de coerência numa das direções ([1 T0]) em relação à outra, se traduzindo por um alargamento das linhas de difração. Este efeito é provocado pela assimetria da forma das ilhas que são mais compridas na direção [1 10] que na direção perpendicular $[110]^{70}$, oferecendo uma condição de difração inferior. Este efeito pode ser explicado pela orientação das ligações pendentes de uma superfície rica em arsênio que são alinhadas com a direção [1 10$]$. Como o dímero entre dois átomos de arsênio é formado nesta mesma direção, a difusão superficial dos átomos de gálio se torna anisotrópica: ela será favorecida na direção [1 $\overline{1}$ 10], já que para difundir na direção perpendicular precisará quebrar a ligação dimérica, o que necessitará uma certa energia, aumentando assim a energia de ativação da difusão nesta direção.

O surgimento de substratos desorientados intencionalmente de alguns graus melhorou significativamente a qualidade das amostras crescidas, tanto a nível da estrutura cristalina quanto das propriedades optoeletrônicas. Levantou também várias dúvidas sobre a interpretação física das oscilações da intensidade do feixe especular. Neste tipo de substrato, a densidade de terraços é uma função do ângulo de desorientação e acaba modificando o modo de crescimento. Enquanto o comprimento de difusão dos átomos de gálio for menor que a largura dos terraços, haverá nucleação bidimensional e o modo de crescimento descrito anteriormente será adotado. Todavia, dependendo das condições de crescimento (da temperatura do substrato e da razão dos fluxos principalmente) e do ângulo de desorientação, o comprimento de difusão pode ser maior que a distância entre os terraços, e os átomos serão preferencialmente incorporados na beira dos degraus. Neste caso, não há mais nucleação, mas sim uma propagação dinâmica das bordas dos terraços. Este modo de crescimento por avanço dos degraus não leva a nenhuma variação da intensidade do feixe especular, já que não há nucleação e que o espalhamento pela superfície não é modificado.

Com a chegada no mercado mundial das novas técnicas de investigação local de superficie, foi claramente evidenciado ${ }^{71}$ que mesmo após o crescimento de centenas de camadas 
sobre um substrato nominal, a rugosidade natural da superfície (definida no sentido usual) não tinha aumentado, ao contrário do que se especulava anteriormente. Simulações recentes do crescimento pelo método de Monte Carlo comprovaram ${ }^{72}$ estes dados, e foi então proposto que as oscilações da intensidade do feixe especular não fossem relacionadas com a rugosidade da superfície provocada pela nucleação, mas sim devida à variação da densidade de bordas presentes na superfície. Este modelo não é incompativel com o modo de nucleação, já que a presença de ilhas aumenta o número de bordas disponiveis para o espalhamento do feixe incidente. Explica também de maneira mais convincente a diminuição progressiva da intensidade do feixe especular pelo estabelecimento de um equilibrio do número de bordas, sem invocar a necessidade de um aumento da rugosidade. A ausência de oscilações no caso dos substratos desorientados é justificada naturalmente pela densidade constante das bordas, já que as únicas bordas presentes são as dos terraços, cujo número não varia, por definição do modo específico de crescimento por avanço de degraus. Este equilíbrio local durante o crescimento explica também porque, apesar da técnica MBE ser realizada fora do equilíbrio, a qualidade cristalina final é tão boa.

O modelo de crescimento de ligas ternárias compostas por dois elementos diferentes da família III (o alumínio e o gálio por exemplo) e um elemento da família V (o arsênio) é basicamente o mesmo. No caso da liga $\mathrm{Al}_{\mathrm{x}} \mathrm{Ga}_{1-\mathrm{x}} \mathrm{As}$, a principal diferença está relacionada com a maior energia de coesão do AlAs que se traduz por uma energia de ativação maior para a difusão dos átomos de alumínio. Portanto, em condições iguais de crescimento, os átomos de alumínio serão menos móveis, o que acaba provocando novos fenômenos tais como rugosidade da superfície, desordem da liga, enriquecimento de algumas regiões num dos materiais e segregação. Uma outra dificuldade é que, para obter-se uma camada espessa com a mesma concentração relativa das duas espécies da família III, a razão dos fluxos precisa ser mantida constante, necessitando células com boa estabilidade.

\section{I.4 - Calibração dos fluxos de materiais}

\subsection{1 - Taxas de Crescimento}

As oscilações da intensidade luminosa do feixe especular podem ser usadas para determinar-se a taxa de crescimento dos materiais. Como ela é associada à cobertura completa por uma camada de material, seu período representa o tempo de crescimento desta camada e 
pode ser usado como referencia pelo computador para determinar o tempo de abertura necessário de cada obturador para alcançar a espessura desejada das camadas epitaxiais durante o crescimento de uma estrutura. Gravando as oscilações por um certo tempo, pode-se determinar com precisão o período $T$ da oscilação e a taxa de crescimento $V$. Os principais erros experimentais desta técnica são a medida do tempo necessário para obter um dado número de oscilações, e a determinação exata do número de oscilações. O erro sobre o tempo depende do método utilizado para sua medida (cronômetro, plotter ou computador), enquanto que o erro visual da determinação de um número inteiro de oscilações pode ser estimado em $5 \%$ de uma oscilação. Na direção de crescimento [001], uma monocamada de GaAs representa a metade do parâmetro de rede $a$, e portanto,

$$
V=\frac{1}{T}[M c / s]=\frac{a / 2}{T}[\AA / s] .
$$

Na hora da abertura do obturador das células, existe um transiente de temperatura que se traduz por um transiente de fluxo e uma variação rápida da freqüencia das primeiras oscilações. A abertura do obturador provoca uma baixa sensível da temperatura da superfície da carga de

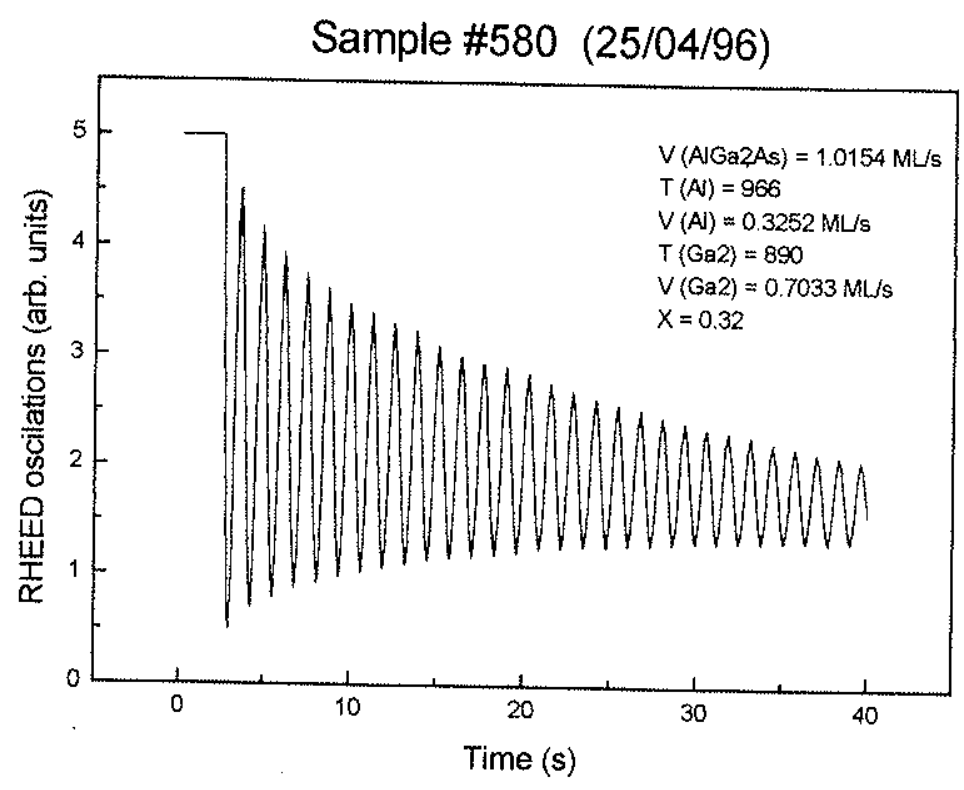

Figura ll-15 - Tipica figura mostrando as oscilaçôes RHEED durante o crescimento de GaAs sobre uma amostra (de nimero 580).

material presente na célula que passa a evaporar menos. As primeiras oscilações apresentam uma freqüência maior e precisam portanto ser descartadas da medida para evitar erros grosseiros.

O período das oscilações é independente da direção do feixe incidente, mas sua 
amplitude é fortemente variável. Para observarem-se oscilações bem definidas, o feixe deve ser orientado perpendicularmente à direção contendo a maior densidade de degraus. Devido à anisotropia da forma das ilhas, a direção mais favorável é [110], já que a difusão superficial é privilegiada na direção perpendicular [ 1 Tl0].

\section{II.4.2 - Concentração das Ligas ternárias}

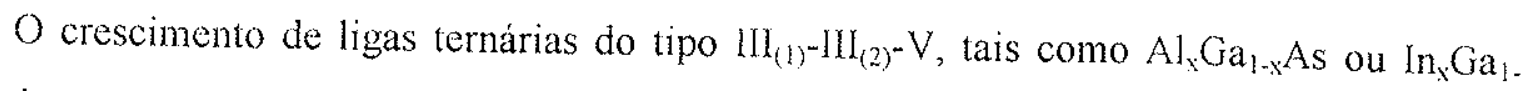
AAs, pode ser considerado como sendo o crescimento simultâneo de duas ligas binárias III-V se o coeficiente de colagem da familia III for unitário na faixa de temperatura adotada. Portanto, para determinar a concentração $x$ de um elemento em uma liga ternária, pode-se utilizar o argumento que a taxa de crescimento da liga ternária é a soma das taxas das duas ligas binárias,

$$
V_{I I I_{(1)}-I I_{(2)-V}}=V_{I I I_{(1)}-V^{\prime}}+V_{\left(I_{(2)-3}\right.} \text {. }
$$

Assim, a concentração $x$ do elemento $\operatorname{III}_{(1)}$ na liga pode ser calculada por

$$
x=\frac{V_{I I_{(1)}-V}}{V_{I I_{(1)}-I I_{(2)}-V}}=\frac{V_{I I_{(1)}-V}}{V_{I I I_{(1)}-V}+V_{I I I_{(2)}-V}} \text {. }
$$

Deste modo, o conhecimento da velocidade de crescimento dos dois materiais binários, ou de um deles e da liga ternária, permite a determinação da concentração relativa dos elementos III.

O principal problema na obtenção de uma liga ternária, de boa qualidade e conforme às especificações nominais, é a compatibilidade entre as duas ligas binárias que precisam possuir condições de crescimento parecidas. O caso do AlAs e GaAs é o mais favorável, pois possuem um parâmetro de rede muito parecido e condições de crescimento próximas: a temperatura ideal de crescimento do AlAs está em torno de $680^{\circ} \mathrm{C}$ (contra $580^{\circ} \mathrm{C}$ para o GaAs) e precisa também de um fluxo de arsênio mais alto. O caso do InAs e GaAs é muito mais complexo, pois além do InAs possuir uma temperatura ideal de crescimento em torno de $520^{\circ} \mathrm{C}$ e a necessidade de um fluxo de arsênio mais alto, seu parâmetro de rede é muito diferente do GaAs ( $7 \%$ maior), o que limita consideravelmente a espessura das camadas epitaxiais. A baixa energia de coesão do InAs favorece o fenômeno de segregação ${ }^{73,74}$ (que existe a qualquer temperatura) e a evaporação do indio acima de $530^{\circ} \mathrm{C}$.

\subsection{3 - Curvas de calibração}

Na prática, costuma-se usar taxas de deposição da ordem de uma monocamada por 
segundo $(1 \mathrm{Mc} / \mathrm{s})$, o que equivale a $1 \mu \mathrm{m}$ por hora (exatamente $1,018 \mu \mathrm{m} / \mathrm{h}$ ) para a direção de crescimento [001]. No caso de ligas ternárias, esta mesma taxa é empregada, mas precisa-se usar uma razão de fluxos dos elementos da família III bem precisa para obter a concentração relativa desejada. Para evitar uma calibração passo a passo pela técnica RHEED, o que pode levar horas, costuma-se fazer uma curva de calibração da taxa de evaporação dos elementos em função da temperatura da célula. Esta curva precisa ser feita mensalmente para compensar a perda de material ocorrida durante as numerosas horas de uso.

Nesta calibração, a temperatura das células dos elementos da família III é variada entre dois valores extremos, sendo que a intervalos regulares, e após um tempo necessário para estabilizar os fluxos, a taxa de crescimento é determinada com o sistema RHEED. Como a

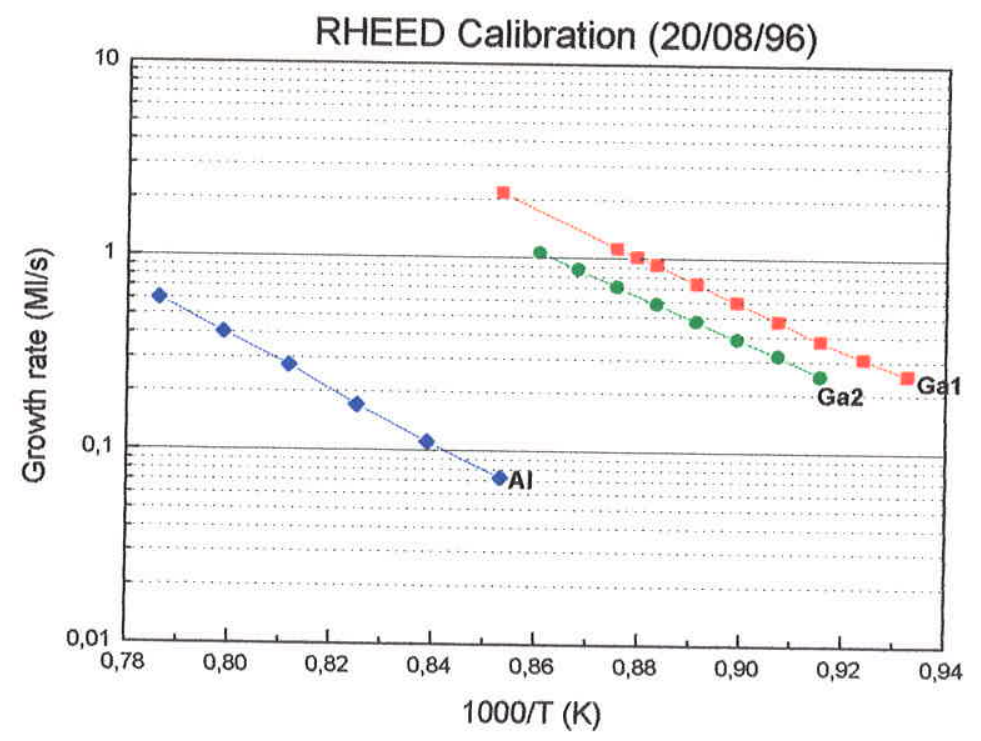

Figura II-16 - Taxa de deposição (em monocamadas por segundo) em função da temperatura dos fornos de alumínio e gálio (2 fornos); os dados foram obtidos por medidas realizadas com o sistema RHEED.

evaporação é um processo termicamente ativado, a taxa de crescimento $V$, que é proporcional ao fluxo de partículas, possui a dependência

$$
V=V_{0} \exp \left(-E_{a} / k T\right) .
$$

onde $E_{a}$ é a energia de ativação para a evaporação dos átomos da família III. Num gráfico de $V$ em função de 1/T (gráfico de Arrhenius), esta função é representada por uma reta, cujo coeficiente angular é $-E_{a}$. 


\section{II.4.4 - Calibração do GaAs}

Para a calibração do GaAs, a temperatura do substrato deve estar em torno de $580^{\circ} \mathrm{C}$, que é o valor ideal para o crescimento de uma camada desta natureza. As medidas são feitas a partir de uma taxa mínima, onde ainda se consegue oscilações, até uma taxa de $1 \mathrm{Mc} / \mathrm{s}$ aproximadamente. A qualidade das oscilações depende da razão de fluxos V/III, sendo que para valores altos, a grande população de átomos de arsênio diminui a difusão superfícial e acaba prejudicando a qualidade do crescimento, diminuindo consideravelmente a amplitude e o número das oscilações. Portanto, taxas abaixo de $0,3 \mathrm{Mc} / \mathrm{s}$ são dificilmente medidas sem mudar o fluxo de arsênio, o que é muito incômodo. Como possuímos duas células de gálio, este problema pode ser solucionado pelo uso das duas células simultaneamente, sendo que uma deve ser calibrada anteriormente com uma taxa superior a $0,5 \mathrm{Mc} / \mathrm{s}$, e que a taxa da segunda será encontrada pela subtração da taxa total e a da outra célula, já que

$$
V_{G a_{1}+G a_{2}}=V_{G a_{1}}+V_{G a_{2}}
$$

onde $\mathrm{Ga}_{1}$ e $\mathrm{Ga}_{2}$ indicam as diferentes células de gálio.

\section{II.4.5 - Calibração do AlAs}

Para o crescimento deste material, a temperatura do substrato deve ser mais alta (acima de $620^{\circ} \mathrm{C}$ ) do que a usada para o crescimento do GaAs de maneira a observarem-se oscilações de boa qualidade. O resto do procedimento é idêntico ao do GaAs, sendo que a taxa de crescimento do AlAs pode ser determinada a partir da liga binária ou ternária com gálio.

\section{II.4.6 - Calibração do InAs}

O crescimento desta liga requer que a temperatura do substrato seja ajustada em torno de $520^{\circ} \mathrm{C}$, devido à mais baixa energia de ligação dos átomos de índio no cristal. Caso a temperatura seja alta demais, a energia térmica será suficiente para quebrar as ligações e diminuir o coeficiente de incorporação do índio na amostra (o indio entra no cristal e evapora logo depois). Além deste problema de temperatura, o InAs tem uma diferença de parâmetro de rede de $7 \%$ em relação ao GaAs, o que impede o crescimento de camadas epitaxiais tensionadas acima de uma certa espessura crítica, que depende basicamente da temperatura do substrato e da concentração de índio na liga $\ln _{\mathrm{x}} \mathrm{Ga}_{1 \times x}$ As. Acima desta espessura crítica, a energia elástica armazenada é relaxada pela formação de deslocações, produzindo uma superfície rugosa que 
impossibilita qualquer medidas pelo sistema RHEED. Portanto, para calibrar a taxa de evaporação do forno de índio, medimos a velocidade de crescimento de uma liga $\ln _{x} G a_{1-x}$ As, com baixo teor de indio (entre 10 e $20 \%$ ), e do GaAs, e obtemos a velocidade do InAs por simples subtração:

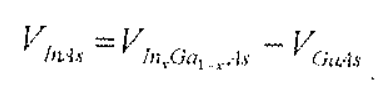

Para determinar a concentração $x$ de índio na liga $\ln _{x} \mathrm{Ga}_{1-x} \mathrm{As}$, usamos a relação

$$
x=\frac{V_{\text {hLts }}}{V_{\text {Ints }}+V_{\text {Gads }}}
$$

Como todas as calibrações são realizadas sobre um pequeno substrato destinado a este fim, as camadas tensionadas de $\mathrm{In}_{\mathrm{X}} \mathrm{Ga}_{1-\mathrm{x}}$ As precisam ser cobertas por uma camada espessa $(1000 \AA)$ de GaAs ou removidas para que elas não prejudiquem as calibrações posteriores. Optamos pelo segundo procedimento que é muito mais rápido e diminui consideravelmente a probabilidade de criar defeitos importantes na amostra de calibração. Para remover o $\ln _{x} \mathrm{Ga}_{1-\mathrm{x}} \mathrm{As}$, a amostra é aquecida in situ até $600^{\circ} \mathrm{C}$ por 30 segundos, o que evapora quase que completamente todos os átomos de índio e produz uma superfície lisa de GaAs. 


\section{III - Otimização dos parâmetros de crescimento de GaAs e $\mathrm{Al}_{\mathrm{x}} \mathrm{Ga}_{1-\mathrm{x}} \mathrm{As}$}

\section{III.1 - Introdução}

A técnica MBE possibilita a deposição de camadas epitaxiais cristalinas de alta qualidade e pureza. Devido à sua baixa taxa de crescimento (em torno de $1 \mu \mathrm{m} / \mathrm{h}$ ), esta técnica não é muito adequada para obterem-se camadas espessas. Sua maior aplicação reside na possibilidade de crescerem-se camadas finas, com precisão atômica, combinando materiais de natureza diferente. Todavia, para chegar a um resultado satisfatório, as ligas precisam possuir um parâmetro de rede muito parecido e condições de crescimento as mais próximas possíveis. O GaAs é geralmente combinado com a outra liga binária AlAs, pois, juntamente, podem produzir uma liga ternária $\mathrm{Al}_{\mathrm{x}} \mathrm{Ga}_{1-\mathrm{x}} \mathrm{As}$ possuindo, dependendo do valor de $x$, um gap variando entre os valores do gap do GaAs (1.42eV a 300K) e do AlAs (2,16eV a $300 \mathrm{~K})$, sendo que o parâmetro de rede dos dois materiais é respectivamente $5,6533 \AA$ e $5,6605 \AA$. Todavia, como estas ligas possuem condições de crescimento ligeiramente diferentes, devido principalmente à maior energia de coesão do AlAs, elas precisam ser anteriormente determinadas para, depois, encontrar um compromisso e crescer os dois materiais na mesma amostra.

Duas técnicas de caracterização ex situ foram empregadas para analisar a qualidade cristalina e óptica dos conjuntos de amostras crescidos. As medidas de fotoluminescência foram realizadas em nosso grupo e fornecem informações sobre a energia do gap dos materiais, a presença de impurezas na estrutura crescida e a rugosidade das interfaces entre materiais diferentes. A amostra é colocada num criostato, que pode ser resfriado à temperatura do hélio líquido, possuindo janelas ópticas para permitir a entrada de uma radiação monocromática (oriunda de um laser) cuja energia é maior que o valor do gap do material a ser investigado. Quando a radiação incide sobre a amostra, elétrons da banda de valência são excitados para a banda de condução onde termalizam até o fundo da banda e recombinam radiativamente com os buracos da banda de valência, emitindo um fóton de energia igual ao valor do gap (na verdade um pouco inferior devido à energia de ligação do par elétron-buraco, chamado de éxciton). A radiação emitida pela amostra é recolhida por um sistema de lentes e focalizada na entrada de um monocromador. Uma fotomultiplicadora posicionada na saída do monocromador transforma a intensidade luminosa em sinal elétrico, possibilitando a aquisição dos dados por um 
computador. Variando o comprimento de onda selecionado pelo monocromador (girando a rede de difração), obtém-se então, o espectro energético da radiação emitida pelas camadas crescidas. A presença de impurezas introduz um nível raso dentro do gap que também pode ser observado no espectro.

As medidas de raios $\mathrm{x}$ foram realizadas pelo professor Morelhão utilizando-se um difratômetro de duplo cristal. O sistema é constituído por um tubo de raios $X$, um cristal monocromador, a amostra (que é o segundo cristal do instrumento) e um detector. O feixe policromático oriundo do tubo de raio X é incidido sobre o cristal monocromador (de GaAs neste caso) que seleciona, por reflexão de Bragg, um único comprimento de onda. Esta radiação monocromática incide sobre a amostra a ser investigada que pode ser girada de maneira a satisfazer uma condição de Bragg. A medida consiste então em girar a amostra por passos pequenos em torno de uma reflexão de Bragg e medir ponto a ponto a intensidade dos raios $\mathrm{x}$ difratados, com o detector. Este tipo de medida é muito usada para determinar o parâmetro de rede do cristal ou para detectar a presença de defeitos estruturais que costumam alargar os picos de difração.

\section{III.2 - Razão de fluxo dos elementos das famílias V e III}

No primeiro conjunto de amostras, a razão de fluxo dos elementos V e III foi variada entre dois valores extremos. Este parâmetro é importante ${ }^{75}$ pois deve possuir um valor mínimo para repor os átomos de arsênio evaporados da superfície do substrato em razão da alta temperatura adotada para o crescimento (em torno de $600^{\circ} \mathrm{C}$ ). Um alto fluxo de arsênio prejudica a qualidade da amostra porque diminui a difusão dos átomos da família III e, acima de um certo valor, favorece a incorporação dos átomos de arsênio nos sítios do gálio, criando assim defeitos do tipo antisítio que produzem níveis profundos ${ }^{76}$. Como a medida do fluxo depende bastante do tipo de medidor que é empregado e de sua calibração, e que a pressão equivalente do fluxo de arsênio é geralmente muito maior que a do gálio, a medida do flủxo de gálio é facilmente mascarada pela pressão de fundo e pode apresentar erros consideráveis. Optamos por uma outra medida, relacionada com a razão dos fluxos, que é a medida da razão de velocidade de incorporação dos elementos V e III estimada pelo sistema RHEED. Este método possui a vantagem de medir o que é realmente incorporado na amostra e não simplesmente o que incide nela (e poderia muito bem não ser incorporado). A taxa de crescimento definida no capítulo anterior corresponde à taxa de incorporação dos átomos de gálio. Como o arsênio possui um coeficiente de colagem nulo sobre uma superfície rica em arsênio (esta é a condição geral do 
crescimento), a única maneira de medir sua taxa de incorporação é criar uma superfície rica em gálio (evaporando algumas camadas de gálio sobre o substrato) e observar as oscilações do feixe especular quando o arsênio é consumido pelas camadas de gálio (este efeito será demonstrado e utilizado no quarto capítulo). Crescemos portanto um conjunto de amostras de GaAs variando a razão de velocidade de incorporação dos dois elementos entre 1,6 e 3,8, mantendo constante a taxa de crescimento. Para isto, a célula de gálio foi colocada numa determinada temperatura, enquanto que, de uma amostra para a outra, a temperatura da célula de arsênio ia mudando. Após cada mudança de temperatura, esperou-se uma hora para deixar estabilizar o fluxo de partículas. As condições de crescimento de cada amostra foram descritas na Tabela III-1.

\begin{tabular}{ccccc}
\hline \hline Amostra & $\mathrm{T}_{\mathrm{As}}\left({ }^{\circ} \mathrm{C}\right)$ & $\mathrm{V}_{\mathrm{As}}(\mathrm{ML} / \mathrm{s})$ & $\mathrm{V}_{\mathrm{Ga}}(\mathrm{ML} / \mathrm{s})$ & $\mathrm{V}_{\mathrm{As}} / \mathrm{V}_{\mathrm{Ga}}$ \\
\hline \hline 662 & 255 & 1.8 & 0.70 & 2.5 \\
663 & 252 & 1.5 & 0.71 & 2.1 \\
664 & 246 & 1.1 & 0.70 & 1.6 \\
666 & 258 & 2.3 & 0.73 & 3.1 \\
667 & 261 & 2.7 & 0.70 & 3.8 \\
\hline
\end{tabular}

Tabela III-1 - Parâmetros usados para o crescimento das amostras do primeiro conjunto (1 1 m de espessura).

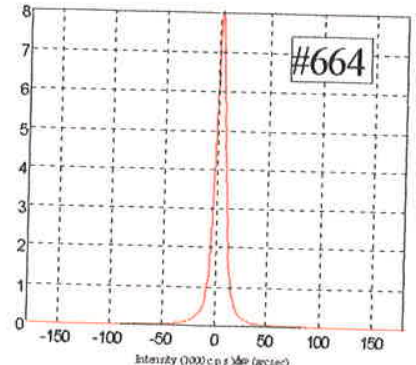

(a)

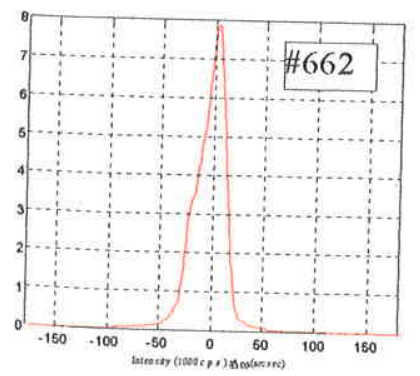

(c)

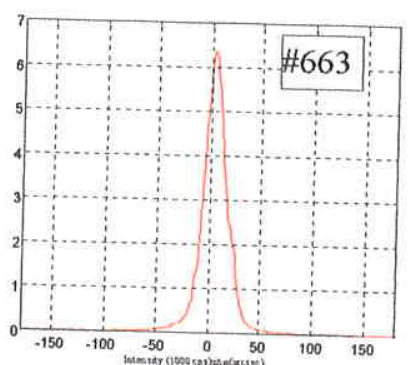

(b)

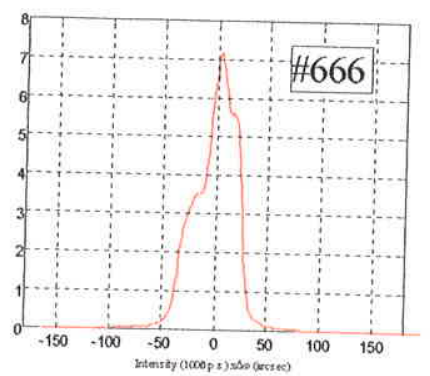

(d)
Figura III-1- Espectro de difração de raios $X$ (Intensidade[1000 cps]X $\Delta \omega[\operatorname{arcsec}]) d o$ conjunto de amostras crescido com razão crescente de velocidades de incorporação VIIII; (a)\#664, (b)\#663, (c)\#662, (d) \#666, (e)\#667.

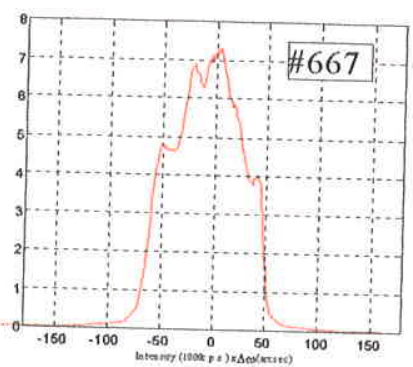

(e)

Medidas de difração de raios X mostraram que a amostra \#664, crescida com a razão mais baixa, apresentou uma estrutura cristalina de excelente qualidade comprovada pela presença de um único pico de difração com largura próxima à largura teórica. Com o aumento da razão de velocidades, outros picos aparecem, indicando a existência de regiões com parâmetro de rede ligeiramente diferente, provavelmente por causa da presença de defeitos estruturais. Portanto, no caso do GaAs, a razão de velocidades (ou de fluxos) precisa ser mantida 
tão baixa quanto possivel para garantir uma estrutura cristalina de excelente qualidade. Como o crescimento de camadas de AlGaAs requer geralmente um fluxo mais alto que para o caso do GaAs, um compromisso deverá ser realizado.

\section{III.3 - Interrupção de crescimento nas interfaces}

Vimos no segundo capítulo que, durante o crescimento, a variação da intensidade luminosa do feixe especular ia diminuindo progressivamente, sendo que logo após o final do crescimento, esta voltava a aumentar até o valor inicial. Este efeito foi inicialmente atribuído ao alisamento da frente do crescimento que tinha se tornado mais rugosa. Portanto, quando se juntam dois materiais de natureza diferente, a interface entre as duas camadas se torna também rugosa, o que prejudica algumas propriedades físicas da amostra: os elétrons e éxcitons são mais espalhados, o que leva a um desempenho inferior de algum tipo de dispositivo (como veremos no quinto capítulo) e ao alargamento da linha de emissão de poços quânticos nos espectros de fotoluminescência ${ }^{77,78}$.

Para evitar estes problemas, a técnica de interrupção de crescimento foi inventada ${ }^{79}$, onde, nas interfaces, o crescimento é interrompido durante um certo tempo para permitir o alisamento da superfície. Quando o crescimento do segundo material é iniciado, este ocorre sobre uma superficie mais lisa, o que diminui a rugosidade da interface. Portanto, amostras com interrupção de crescimento nas interfaces deveriam apresentar um espectro de luminescência mais estreito.

Crescemos um conjunto de quatro amostras contendo um poço quântico de $100 \AA$ com barreiras de $\mathrm{Al}_{0,3} \mathrm{Ga}_{0,7} \mathrm{As}$ de $300 \AA$ de largura como indicado na Figura III-2. Uma estrutura de poço quântico é formada quando uma camada fina de material é cercada por duas camadas de

\begin{tabular}{cc}
\hline Amostra & Tempo (s) \\
\hline$\# 930$ & 0 \\
$\# 931$ & 30 \\
$\# 932$ & 60 \\
$\# 933$ & 300 \\
\hline
\end{tabular}
Tabela III-2 - Tempo de interrupçăo de crescimento realizado nas duas interfaces das amostras do segundo
conjunto.

um outro material possuindo um gap maior que o primeiro. Desta maneira, existe uma descontinuidade do potencial nas interfaces, formando um poço de potencial onde os portadores extrínsecos ou fotogerados poderão ser confinados, exibindo novas propriedades típicas de 
sistemas bidimensionais. O tempo de interrupção nas interfaces foi variado para cada amostra e medidas de fotoluminescência foram realizadas para conferir o estado das interfaces (Tabela III2). As temperaturas de crescimento para as camadas de $\mathrm{AlGaAs} / \mathrm{GaAs}$ foram de $600^{\circ} \mathrm{C}$ e $580^{\circ} \mathrm{C}$,
respectivamente.

Observa-se na Figura III-3 que a amostra de melhor qualidade é aquela cujo crescimento não foi interrompido nas interfaces, já que apresenta o sinal mais intenso e a menor largura a meia altura. Quando a interrupção de crescimento vai aumentando, a intensidade do pico principal $(1,55 \mathrm{eV})$ vai baixando e alargando, ao contrário do resultado esperado. Todavia, este comportamento não é incompatível, já que ele simplesmente significa que o tempo de interrupção não diminui a rugosidade da interface. É conhecido que o alumínio possui um coeficiente de difusão superficial menor que o do gálio ${ }^{80}$, produzindo portanto ilhas de menor tamanho e uma maior rugosidade. Todavia, como a energia de coesão do AlAs é maior que a do GaAs, o rearranjo das ilhas durante a interrupção de crescimento na superfície de AlGaAs é mais fraco, minimizando o efeito de qualquer interrupção. O contrário não é verdade para a outra interface, onde o GaAs é depositado sobre a camada de $\mathrm{AlGaAs}^{81,82}$. Vários trabalhos mostraram que as interrupções são muito eficientes para a camada de GaAs cujos átomos de gálio são mais móveis, possibilitando o rearranjo das ilhas durante a interrupção. Nosso resultado indica que a rugosidade de nossas amostras é controlada pela rugosidade da interface $\mathrm{AlGaAs} / \mathrm{GaAs}$ sobre a qual a interrupção não tem muito efeito. Um outro acontecimento visível na Figura III-3 é a presença de um segundo pico na amostra \#933, $12 \mathrm{meV}$ abaixo da transição principal, que se caracteriza por uma leve assimetria nas amostras \#931 e \#932. Este efeito foi mencionado recentemente numa tese de nosso grupo ${ }^{83}$ e atribuído à incorporação de carbono na interface AlGaAs/GaAs. Como este elemento é pouco solúvel no $\mathrm{AlGaAs}^{84}$, ele não é incorporado, mas sim flutua sobre a superfície, tanto durante o crescimento quanto a interrupção. Quando o crescimento da camada de GaAs é iniciado, ele é incorporado rapidamente (i.e. principalmente na interface), e possui ${ }^{85}$ uma energia de ligação da ordem de $12 \mathrm{meV}$ para um poço de $100 \AA$ de largura (esta energia depende da largura do poço). Portanto, com tempos de interrupção mais longos, mais impurezas serão incorporadas na interface, produzindo o efeito extremo observado na amostra \#933. Este efeito foi muito acentuado, pois, nesta época, nosso sistema de bombeamento por sublimação de titânio estava fora de uso, o que impossibilitou a remoção deste tipo de impureza do gás residual. Neste conjunto de amostras, as barreiras de AlGaAs foram crescidas a $600^{\circ} \mathrm{C}$ enquanto que as camadas de GaAs do buffer, do poço e da camada superior foram depositadas a $580^{\circ} \mathrm{C}$. Podemos assim concluir que para estes parâmetros de 
crescimento, a rugosidade da amostra é localizada na interface AlGaAs/GaAs sobre a qual a interrupção de crescimento possui uma influência desprezível. Interrupções de crescimento nesta interface poderiam ser evitadas, já que não possuem nenhum efeito e contaminam a camada de GaAs com a incorporação de carbono na interface.

\section{GaAs $100 \AA$ $\frac{\mathrm{Al}_{\mathrm{x}} \mathrm{Ga}_{1-\mathrm{x}} \mathrm{As} 300 \AA}{\mathrm{GaAs} 100 \AA}$ $\frac{\mathrm{Al}_{\mathrm{z}} \mathrm{Ga}_{1-\mathrm{x}} \mathrm{As} 300 \AA}{\text { Buffer GaAs } 0,5 \mu \mathrm{m}}$ Substrato GaAs(100) S-I}

Figura III-2 - Estrutura de um poço quântico de GaAs de $100 A$, com barreiras de $A l_{x} G a_{1-x} A$ s de $300 A$ de largura
contendo $30 \%$ de aluminio.

Como já mencionamos no segundo capítulo, a oscilação da intensidade luminosa do feixe especular não é provocada pela rugosidade (no sentido habitual) das camadas, mas sim pela densidade de bordas presentes na superfície. Isto foi claramente demonstrado em vários

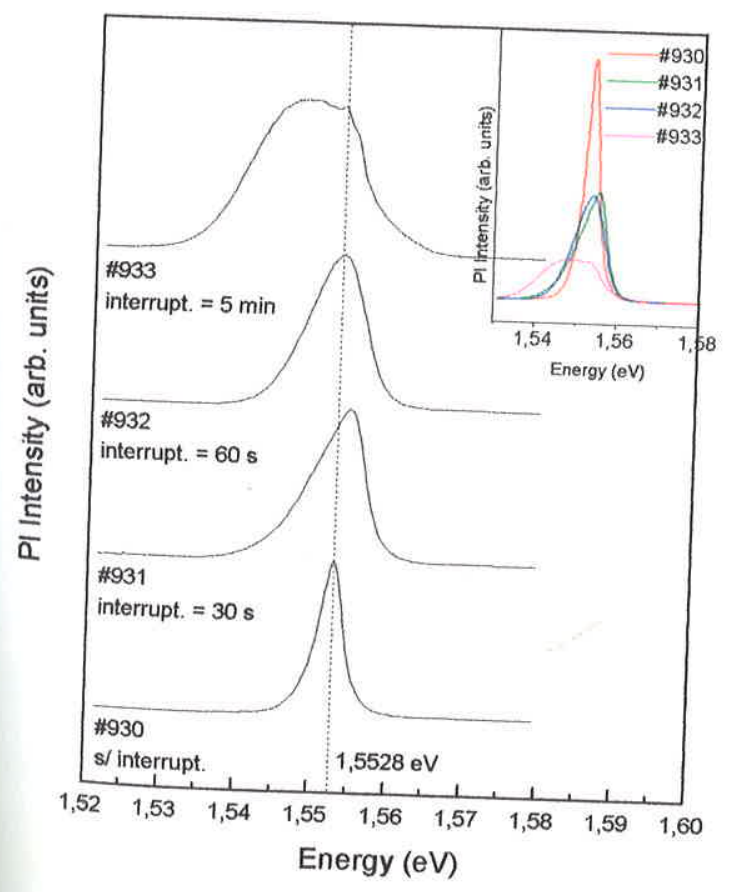

Figura III-3 - Fotoluminescência (PL) das amostras de poços de GaAs/Al $G a_{l_{-x}}$ As com variação do tempo de interrupção nas interfaces. A estrutura das amostras é composta de um único poço de $100 \AA$ e barreira de $300 \AA$ $\operatorname{com} x=0,3$.

experimentos que evidenciaram ${ }^{86,87}$ uma rugosidade quase que constante e independente do número de camadas crescidas. Portanto a interrupção de crescimento não alisa a superfície (já 
que ela não é mais rugosa), mas sim redistribui as ilhas para que elas formem entidades maiores e mais estáveis, diminuindo assim o número de bordas e aumentando a refletividade da superfície. Ilhas maiores espalham muito menos os portadores e os éxcitons já que providenciam, uma menor densidade de bordas que representam potenciais perturbadores. Portanto, o alisamento de superfície mencionado acima significa na verdade um agrupamento das pequenas ilhas para formar ilhas maiores. Este processo é muito menos eficiente no caso do AlGaAs que do GaAs em razão da diferença de energia de coesão, o que criará então ilhas de menor tamanho e em maior número, aumentando assim o espalhamento. 


\section{IV - Crescimento de camadas dopadas}

\section{IV.1 - Introdução}

A técnica de epitaxia por feixe molecular foi desenvolvida inicialmente para possibilitar a fabricação de filmes finos cristalinos e de alta pureza. Quando se percebeu que este tipo de deposição podia superar os outros métodos em uso na época, muitos esforços foram realizados para levar esta tecnologia na direção da produção de componentes eletrônicos de alto desempenho. Para isto, precisava-se encontrar os materiais adequados para que as camadas semicondutoras produzidas pudessem ser dopadas tanto do tipo $n$ quanto do tipo $\mathrm{p}$.

Os materiais usados na década de 60 para dopar as amostras de GaAs produzidas por LPE (liquid phase epitaxy) eram o telúrio (Te) e o zinco $(\mathrm{Zn})$ que levam a camadas do tipo $\mathrm{n}$ e $\mathrm{p}$ respectivamente. Todavia, estes dois elementos não foram adotados para a técnica MBE em razão da reação entre o telúrio e o arsênio, e do baixo coeficiente de colagem do zinco sobre a superficie (001) do GaAs.

Em 1971, Cho ${ }^{88}$ demonstrou que o silício era um candidato excelente, já que, nas condições usuais de crescimento, ele possuía um coeficiente de colagem unitário. Concentrações de elétrons de até $5 \times 10^{18} \mathrm{~cm}^{-3}$ podiam ser obtidas, sem problema algum, evaporando o elemento durante o crescimento sobre uma superfície rica em arsênio, pois o dopante incorporava principalmente nos sítios do gálio. Acima desta concentração de impurezas, existia uma compensação devido à incorporação do silício no sítio do arsênio, produzindo assim um caráter aceitador. Outros elementos da coluna IV, como o germânio (Ge) e o estanho (Sn), foram também investigados, mas não conseguiram se impor. O estanho, apesar de possibilitar dopagens mais altas ${ }^{89,90,91}$ que com o silício e apresentar um efeito de compensação muito menor, difundia muito no cristal e impossibilitava a obtenção de perfis abruptos de dopagens, tão úteis para a fabricação de dispositivos. O germânio possuía a vantagem de ser anfotérico ${ }^{92}$, apresentando um caráter doador sobre superfícies ricas em arsênio e um caráter aceitador sobre superfícies ricas em gálio. Todavia, devido à má qualidade das amostras geralmente produzidas com uma superfície rica em gálio, ele não superou a importância tecnológica do silício.

O magnésio $(\mathrm{Mg})$ foi o primeiro ${ }^{93}$ dopante usado na técnica MBE para produzir camadas de $\mathrm{GaAs}$ do tipo $\mathrm{p}$. Infelizmente, seu coeficiente de colagem durante o crescimento de uma liga de $\mathrm{Al}_{\mathrm{x}} \mathrm{Ga}_{1-\mathrm{x}} \mathrm{As}$ era tão baixo que ele foi logo abandonado. Em 1976, Ilegems ${ }^{94}$ mostrou 
experimentalmente que o berílio possuía todas as características necessárias para se tornar o elemento ideal para a dopagem do tipo p. Todavia, ultimamente, o carbono está sendo muito usado, pois fornece camadas com dopagem de até $10^{20} \mathrm{~cm}^{-3}$, não é tóxico e possui um coeficiente de difusão menor que o do berílio. Células comerciais já são disponíveis e são baseadas na evaporação de carbono a partir de um filamento de grafita no qual circula uma corrente elétrica.

Nosso sistema MBE possui duas células de efusão para os dopantes, uma destinada ao silício e a outra ao berílio. Esta última está vazia desde 1995, em razão da falta deste elemento em nosso laboratório, e portanto estudos de dopagem com berílio não foram possíveis neste trabalho.

\section{IV.2 - Incorporação não intencional de impurezas}

Mesmo sem usar nenhum tipo de dopante durante o crescimento, as camadas produzidas pela técnica $\mathrm{MBE}$ apresentam geralmente um caráter do tipo p. Este comportamento pode ser explicado de três maneiras: a migração de impurezas provenientes do substrato comercial usado, a incorporação de impurezas pertencentes ao gás residual da câmara, e a qualidade dos elementos usados no crescimento.

O tipo de contaminação mais comum é provocado pela dopagem não intencional por átomos de carbono do gás residual. Eles são produzidos pelo aquecimento dos filamentos elétricos do sistema $\mathrm{MBE}$ assim como das paredes de aço inoxidável e peças metálicas próximas a estes locais. Dependendo das condições do vácuo, concentrações de $10^{14} \mathrm{~cm}^{-3}$ a $10^{15} \mathrm{~cm}^{-3}$ são detectadas nas medidas de fotoluminescência. A incorporação de dopantes através do gás residual pode ser diminuída (além do uso da bomba de titânio e do painel criogênico) pela redução do número de filamentos ligados durante o crescimento, tais como os do sistema RHEED, do espectrômetro de massa e dos medidores de pressão.

A colagem dos substratos sobre os blocos de molibdênio, com índio líquido, é uma outra fonte de contaminação, pois eles são aquecidos até $200^{\circ} \mathrm{C}$ para derreter o índio, e durante este processo são oxidados no ar. O tempo necessário para colar 10 amostras é da ordem de 60 a 90 minutos, período durante o qual as amostras são expostas ao ambiente de nossa sala limpa. Os complexos de carbono, eventualmente adsorvidos durante este processo, não são eliminados pelo tratamento térmico aplicado no vácuo e podem migrar durante o crescimento, resultando em uma dopagem não intencional das camadas superiores. Para resolver este problema, adquirimos recentemente novos blocos de molibdênio que dispensam a colagem com índio e minimizam a 
exposição dos substratos. Como as amostras não são mais coladas sobre uma placa espessa de molibdênio, mas sim presas por uma fina placa de safira, a transferência de calor é mais eficiente, o que necessita menos potência elétrica para aquecer o substrato. Isto diminui a desgaseificação dos filamentos aquecedores e a contaminação da câmara de crescimento (nestas condições, a concentração de carbono é muito menor no gás residual).

A migração das impurezas provenientes do substrato ou da limpeza química pode ser consideravelmente reduzida pelo crescimento de uma super-rede antes da estrutura desejada ${ }^{95}$ Geralmente, usamos 20 pares de camadas AlAs/GaAs, de $20 \AA$ de espessura cada, antes e/ou depois do crescimento da camada buffer.

A única fonte de impurezas que não pode ser controlada externamente vem das cargas de materiais presentes na células de Knudsen. Como estas são orientadas na direção do substrato, qualquer impureza emitida incidirá sobre a superfície da amostra. Portanto, é vital que materiais de alta pureza sejam utilizados. Hoje, cargas com pureza melhor que $7 \mathrm{~N}$ podem ser adquiridas no mercado. Felizmente, a maior parte das impurezas ainda presentes possuem um coeficiente de colagem baixo nas condições usuais de crescimento, o que limita consideravelmente este fator de contaminação.

\section{IV.3 - Incorporação intencional de impurezas}

\section{IV.3.1 - Dopagem do tipo n}

Desde a origem da técnica MBE, o silício foi escolhido com dopante para produzirem-se camadas do tipo n. A evaporação do silício durante o crescimento sobre uma superfície $(001)$ de GaAs favorece sua incorporação no sítio do gálio. Estes dois elementos pertencem respectivamente à coluna IV e III da tabela periódica, o que significa que a substituição do gálio pelo silício fornece um elétron suplementar ao cristal. Entre $500^{\circ} \mathrm{C}$ e $700^{\circ} \mathrm{C}$, o silício possui um coeficiente de incorporação unitário e um coeficiente de ionização máximo, fornecendo desta maneira um elétron por átomo de dopante.

Como o silicio é evaporado em quantidade pequena (em relação aos elementos formando o cristal de GaAs), sua taxa de evaporação não pode ser determinada pelo sistema RHEED*. Portanto, o método mais utilizado é a caracterizaçâo elétrica por medida de efeito Hall. Para isto,

Recentemente, Braun conseguilı evidenciar, pelo sistema RHEED, a deposiçâo de silicio sobre uma superficie de GaAs [W. Braun, L. Däweritz e K. Ploog, J. Appl. Phys. 78, 7, 4472 (1995)] 
crescemos um conjunto de amostras onde uma camada de GaAs de $1 \mu \mathrm{m}$ de espessura é depositada simultaneamente com um fluxo de silício. Cada amostra foi crescida com uma temperatura diferente do forno de silício, i.e. com um fluxo de silício diferente, o que deve produzir concentrações de portadores diferentes. Como a evaporação é um processo termicamente ativado, um gráfico da concentração dos portadores (normalmente igual ao número de átomos de silício no cristal) em função do inverso da temperatura da célula deve evidenciar um comportamento linear.

As medidas de efeito Hall foram realizadas na UNICAMP. Elas consistem na aplicação de uma corrente elétrica entre dois contatos de uma amostra, na presença de um campo magnético perpendicular à superfície. Nestas condições, a Força de Lorentz aplicada sobre os portadores os desvia lateralmente, criando uma diferença de potencial perpendicularmente à

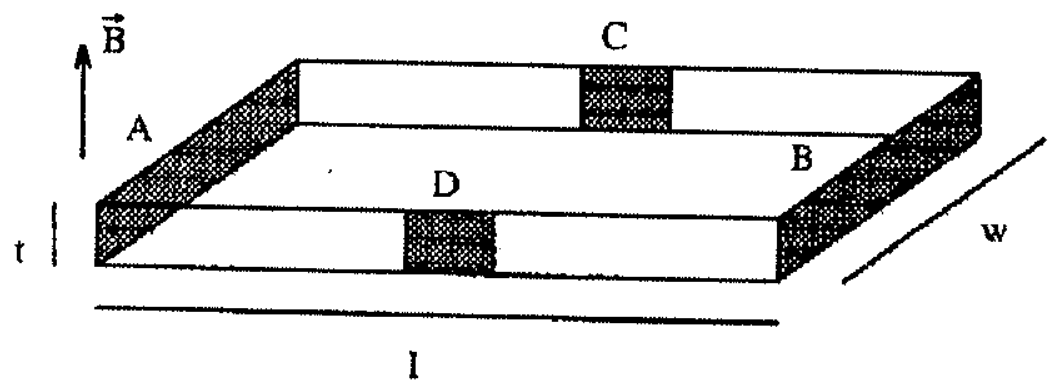

Figura $I V-1$... Geometria simples de uma amostra e dos contatos necessários para realizar uma medida de efeito Hall; $A, B, C$ e D representam os contatos elétricos, enquanto que t, le w são as dimensôes da amostra; a corrente elétrica é aplicada entre $A$ e $B$, e a voltagem de Hall é medida entre $C$ e $D$.

direção da corrente. Esta voltagem, chamada de voltagem de Hall, é uma função da corrente elétrica $I$, do campo magnético $B$ e da espessura $t$ da camada dopada:

$$
V_{H}=R_{H} I B / 1 \text {. }
$$

(IV-1)

onde $R_{H}$ é o coeficiente de Hall,

$$
R_{H}=r_{l l} / q n
$$

$r_{H}, q$ e $n$ são respectivamente o fator de Hall (da ordem de 1), a carga e a concentração dos portadores. É geralmente difícil preparar uma amostra com a geometria da Figura IV-1 e colocar os contatos nas bordas. Portanto, uma outra geometria é mais comumente utilizada (geometria de Van der Pauw), onde os quatro contatos são realizados na superfície da amostra. Van der Pauw demonstrou que neste caso, as mesmas equações eram válidas.

Dois conjuntos de amostras foram crescidos, cujas concentraçôes de portadores foram 
determinadas por medidas de efeito Hall usando a técnica de Van der Pauw. No primeiro conjunto, a temperatura da célula de silício foi variada amplamente para obterem-se concentrações de dopantes muito diferentes e fornecer assim uma curva de calibração para os

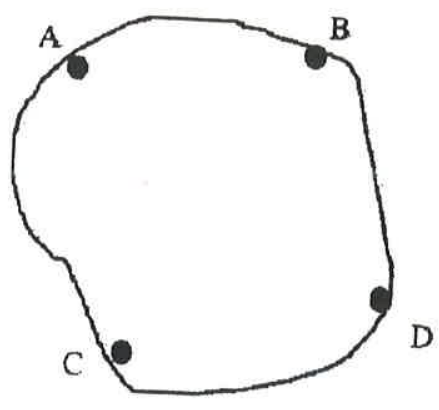

Figura IV-2 - Configuração de Van der Pauw para medidas de efeito Hall; $A, B, C$ e D são os contatos elétricos na
superfície da amostra.

crescimentos posteriores. O segundo conjunto foi crescido com concentrações altas de átomos de silício para evidenciar o limiar de compensação na amostra. Observa-se um comportamento linear no primeiro conjunto, consistente com a incorporação unitária do elemento no cristal.

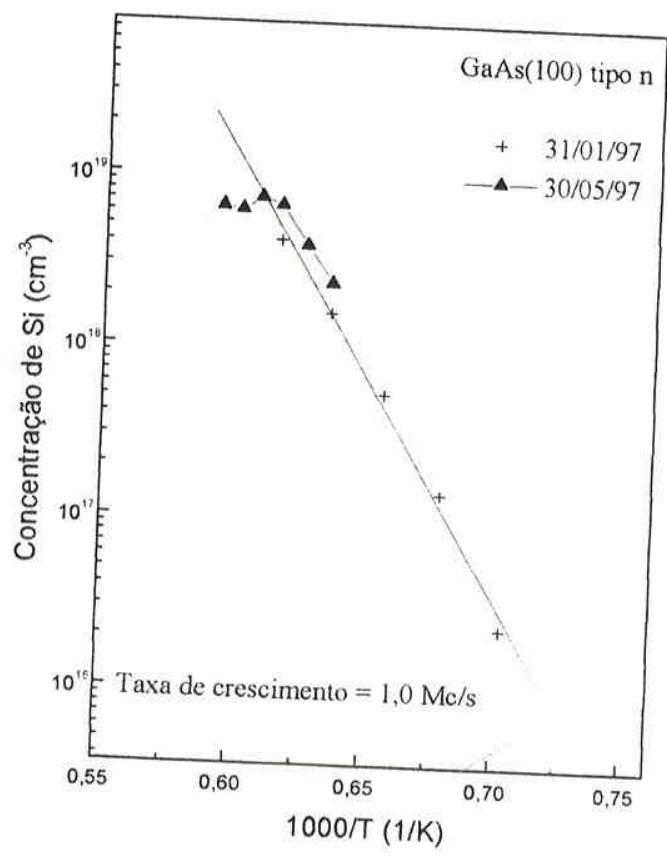

(a)

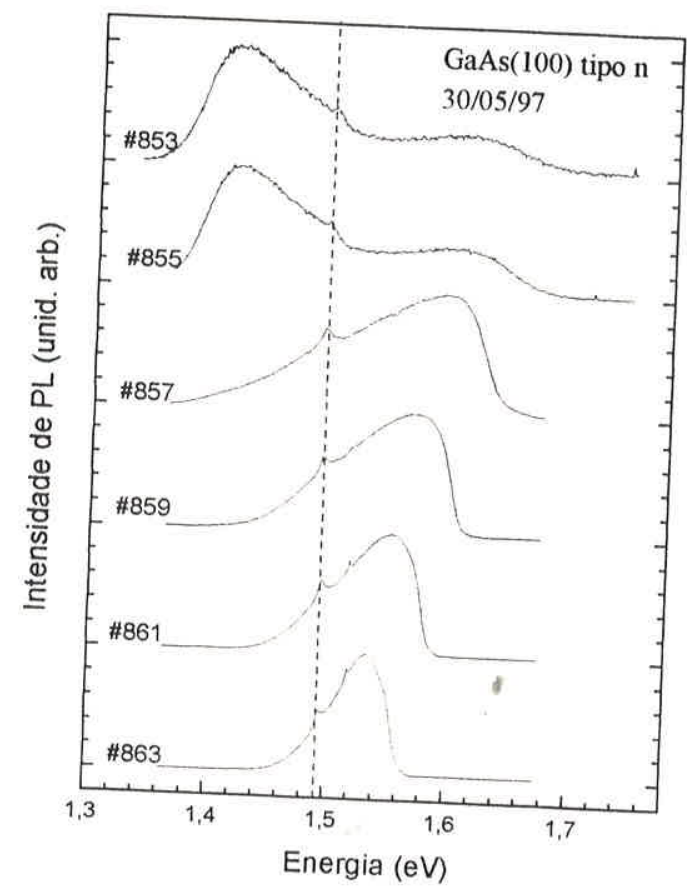

(b)

Figura IV-3 - Medidas de efeito Hall (300K) e de forohiminescencia (l, tK) realiza

amostras de GaAs(100): Si variando-se a temperatura fotoluminescência (1,4K) realizadas sobre os conjuntos de I/T (T é a temperatura do forno de Si): (bjespectro célula de Si; (a)concentração de elétrons em função de (segundo conjunto); ambas as medidas mostram ospectros de fotoluminescência das amostras altamente dopadas 
O segundo conjunto mostra que, a partir de uma concentração de $6 \times 10^{18} \mathrm{~cm}^{-3}$, existe um efeito de compensação que limita a densidade de portadores para os valores mais altos do fluxo de dopante. Este comportamento é observado nas medidas de fotoluminescência, onde se percebe, para os valores mais baixos da concentração, uma banda larga acima do gap do GaAs, cujo máximo vai se deslocando para as altas energias com o aumento da concentração, devido ao aumento do nível de Fermi. A partir de uma certa concentração, aparece uma outra banda larga, em torno de $100 \mathrm{meV}$ abaixo do gap. Essa banda, a 1,42 eV, está distante da emissão radiativa esperada de uma impureza do tipo aceitador $\left(\mathrm{Si}_{\mathrm{As}}\right)$, que está geralmente 20-30 meV abaixo do gap do GaAs. Acredita-se, atualmente, que a compensação é provocada pela formação de um complexo aceitador (chamado Si-X) composto por um átomo de silício no sítio de arsênio e uma vacância de gálio $\left(\mathrm{Si}_{\mathrm{As}}-\mathrm{V}_{\mathrm{Ga}}\right)^{96,97}$.

\section{IV.3.2 - Dopagem do tipo p}

\section{IV.3.2.1 - Substratos (311)A}

A dopagem do tipo p é geralmente realizada com berílio que, na superfície $(001)$ do GaAs, entra no sítio do gálio, criando uma deficiência de um elétron (i.e. fornecendo um buraco ao cristal). O berílio produz um nível aceitador raso, $19 \mathrm{meV}$ acima da banda de valência, e pode ser incorporado ativamente até concentrações de $6 \times 0^{19}$ átomos $/ \mathrm{cm}^{3} \mathrm{com}$ um coeficiente de incorporação unitário. Porém, acima de $10^{19} \mathrm{~cm}^{-3}$, apresenta efeitos pronunciados de segregação e difusão no material hospedeiro.

Apesar de ser ainda o material mais utilizado para este tipo de dopagem, ele apresenta muitos inconvenientes que incentivaram os pesquisadores a procurar um substituto. Ele é muito tóxico e cancerígeno, sendo necessárias precauções extremas durante sua manipulação. É dificilmente evacuado fora do sistema MBE pelos conjuntos clássicos de bombeamento (correndo portanto o risco de contaminar as amostras posteriores) e possui um coeficiente de difusão cerca de 100 vezes maior que o do silício (o que impossibilita a obtenção de perfis abruptos). Além disso, só pode ser produzido com uma pureza de 5N (i.e. 99,999\%), em vez de $7 \mathrm{~N}$ como para todos os outros elementos presentes em nosso sistema MBE, fazendo com que as camadas do tipo p realizadas pelo uso desse material contenham muitas impurezas indesejáveis.

Até hoje, nenhum elemento o substituiu realmente, pois os outros candidatos apresentam problemas de incorporação ou de ionização nas temperaturas usuais de crescimento, ou ainda 
tecnológicos em razão da dificuldade de produzir células de efusão comerciais (foi só recentemente que células sólidas de carbono de boa qualidade começaram a aparecer no mercado). Como, desde 1995, não dispomos deste elemento em nosso laboratório, procuramos uma outra maneira para produzir camadas epitaxiais do tipo $\mathrm{p}$.

Apesar da dopagem com silício produzir sempre amostras do tipo n com substratos de GaAs cortados paralelamente ao plano (001), o fato dele ser anfotérico já é conhecido há muito tempo quando evaporado sobre substratos de GaAs com outras orientações cristalinas. Substratos cortados paralelamente a planos de altos índices de Miller oferecem novas possibilidades a nível das técnicas de crescimento ${ }^{98}$, devido à presença natural de degraus com sítios de natureza diferente. Foi evidenciado que a evaporação simultânea de silício sobre superfícies do tipo (N11)B e (N11)A produzia sempre camadas do tipo $n$ e $p$ respectivamente $^{99,100,101}$ para $\mathrm{N}=1,2$ e 3 . Todavia, é só recentemente ${ }^{102,103,104}$ que foram determinadas as condições específicas de crescimento para produzir camadas do tipo $\mathrm{p}$ com substratos de GaAs cortados paralelamente ao plano (311).

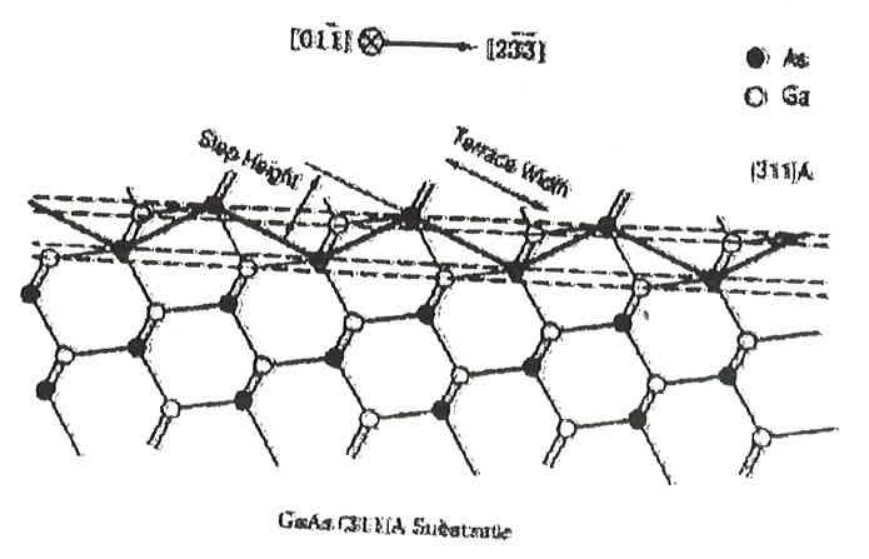

Figura IV-t - Diagrama esquemático das ligações atômicas da superficie do GaAs(311)A projetada no plano
$(110)^{105}$.

Devido ao corte fora dos planos principais da rede cúbica de face centrada, os substratos produzidos ao longo do plano (311) possuem uma alta densidade de degraus náturais de $3 \AA$ de altura e $11 \AA$ de largura. Quando os degraus destes substratos forem terminados com átomos de gálio, o substrato é chamado de (311)A, enquanto que quando os átomos forem de arsênio, ele é denominado (311)B. Devido à distribuição específica dos átomos de gálio e arsênio nesta superfície, ela apresenta um número igual de ligações pendentes simples e duplas, relacionadas respectivamente com os átomos de gálio dos degraus e os átomos de arsênio da superfície (dos terraços). No caso de uma superfície (001), para obterem-se camadas cristalinas de boa 
qualidade, a razão de fluxos dos elementos V/III incidentes na amostra é geralmente mantida entre 1 e 20, o que produz uma superfície sempre rica em arsênio e leva os átomos de dopantes a entrarem preferencialmente nos sítios dos átomos de gálio, atuando então como doadores. Todavia, para os substratos (311)A, os átomos de dopantes têm a possibilidade de entrar tanto no sítio do gálio quanto do arsênio (i.e. no terraço ou na borda respectivamente), dependendo das condições de crescimento. Para baixos valores do fluxo de arsênio e altas temperaturas de crescimento $^{106,107}$, o silício incorpora preferencialmente no sítio do arsênio, pois o coeficiente de incorporação do arsênio é mais baixo (ele tende a reevaporar da superfície) e as moléculas de $\mathrm{As}_{4}$ precisam ser dissociadas para serem incorporadas (é um processo de segunda ordem que favorece a incorporação do silício com a única ligação pendente dos átomos de gálio). A baixa temperatura de crescimento $\left(<450^{\circ} \mathrm{C}\right)$ e altos fluxos de arsênio (razão V/III maior que 5), o coeficiente de incorporação do arsênio volta a ser máximo ( 0,5 para $A s_{4}$ e 1,0 para $\left.A s_{2}\right)$, e uma transformação estrutural aparece ${ }^{108}$ na superfície dos substratos (311)A que diminui o número de ligações pendentes simples em relação ao outro tipo, favorecendo a incorporação do dopante no sítio do gálio e tornando portanto a camada do tipo n.

Esta nova técnica de dopagem apresenta muitas vantagens em relação ao uso do berílio, pois pode-se usar agora um único elemento para os dois tipos de dopagem. Além disso, o silício pode ser obtido com pureza superior à do berílio, não apresenta a dificuldade de evacuação pelas bombas de vácuo, e perfis de dopagem abruptos podem ser realizados sem problema algum (como já vem sendo feito em nosso grupo há vários anos ${ }^{109,110,111,112}$ ), já que seu coeficiente de difusão no material hospedeiro é muito menor que o do berílio. Uma outra grande vantagem do uso dessa orientação é sua menor tendência a incorporar átomos de carbono, como foi demonstrado experimentalmente ${ }^{113}$, minimizando assim os efeitos de dopagem não intencional pelo gás residual.

Para usar esta técnica de dopagem, as condições de crescimento precisam ser controladas com muita precisão ${ }^{114}$, já que os dois parâmetros relevantes para a obtenção de uma camada do tipo $p$ são uma baixa razão dos fluxos V/III (mas não demais para evitar uma superficie rica em gálio) e uma temperatura ajustada para obter uma reconstrução $2 \times 4$ durante o crescimento. Dois conjuntos de amostras foram crescidos sobre substratos (311)A. Estes substratos foram colados lado a lado com as amostras dos dois conjuntos do tipo n, descritos na seção anterior, crescidos sobre substratos $(001)$. Desta maneira, pode-se ter a certeza que as amostras crescidas sobre o mesmo bloco foram expostas a condiçôes idênticas de crescimento, e a amostra (001) servirá sempre de referência já que as condições de crescimento nesta superfície são bem conhecidas. A 
taxa de crescimento do GaAs foi posicionada ao redor de $0,9 \mu \mathrm{m} / \mathrm{h}$ e o substrato foi mantido sob rotação para a máxima uniformidade das camadas crescidas. A temperatura do substrato foi ajustada em $580^{\circ} \mathrm{C}$ e a razão do fluxo dos elementos V e III mantida tão baixa quanto possível $(1,6)$ para otimizar a incorporação do Si nos sítios do arsênio nos substratos (311)A e produzir a dopagem do tipo p. A estrutura das amostras é a mesma que descrita anteriormente, i.e. composta apenas por uma camada de 1,0 $\mu \mathrm{m}$ de GaAs dopado com silício. Cada conjunto de amostras foi crescido em um único dia de maneira a manter as mesmas condições de crescimento para o conjunto inteiro. Detalhes do crescimento e resultados são dados nas tabelas IV-1 e IV-2.

\begin{tabular}{cccc}
\hline $\begin{array}{c}\text { Amostra } \\
(001) /(311) \mathrm{A}\end{array}$ & $\begin{array}{c}\mathrm{T}_{\text {célula de Si }} \\
\left({ }^{\circ} \mathrm{C}\right)\end{array}$ & $\begin{array}{c}\text { Concentração dos } \\
\text { portadores } \\
\left(10^{18} \mathrm{~cm}^{-3}\right)\end{array}$ & $\begin{array}{c}\text { Mobilidade } \\
\left(10^{3} \mathrm{~cm}^{2} / \mathrm{Vs}\right)\end{array}$ \\
\hline $671 / 672$ & 1350 & $4,13 / 4,55$ & $1,75 / 0,11$ \\
$673 / 674$ & 1300 & $1,56 / 1,56$ & $2,10 / 0,12$ \\
$675 / 676$ & 1250 & $0,53 / 0,43$ & $2,91 / 0,18$ \\
$677 / 678$ & 1200 & $0,14 / 0,1$ & $2,80 / 0,26$ \\
$679 / 680$ & 1150 & $0,023 / 0,082$ & $5,35 / 0,07$ \\
\hline
\end{tabular}

Tabela IV-1 - Dados e resultados do crescimento das amostras do primeiro conjunto, usado para a calibração da taxa de evaporação do forno de silicio; uma camada de GaAs dopada com silicio, de lum de espessura, foi depositada sobre substratos de GaAs possuindo uma superficie paralela ao plano (001) - mumeros impares - $e$
(311)A - numeros pares.

\begin{tabular}{cccc}
\hline $\begin{array}{c}\text { Amostra } \\
(100) /(311) \mathrm{A}\end{array}$ & $\begin{array}{c}\mathrm{T}_{\text {célula de Si }} \\
\left({ }^{\circ} \mathrm{C}\right)\end{array}$ & $\begin{array}{c}\text { Concentração dos } \\
\text { portadores } \\
\left(10^{18} \mathrm{~cm}^{-3}\right)\end{array}$ & $\begin{array}{c}\text { Mobilidade } \\
\left(10^{3} \mathrm{~cm}^{2} / \mathrm{Vs}\right)\end{array}$ \\
\hline \hline $853 / 854$ & 1410 & $6,49 / 14,7$ & $0,99 / 0,04$ \\
$855 / 856$ & 1390 & $6,21 / 9,8$ & $1,11 / 0,04$ \\
$857 / 858$ & 1370 & $7,33 / 3,53$ & $1,18 / 0,06$ \\
$859 / 860$ & 1350 & $6,63 / 10,8$ & $1,30 / 0,03$ \\
$861 / 862$ & 1325 & $3,88 / 2,84$ & $1,58 / 0,08$ \\
$863 / 864$ & 1300 & $2,35 / 1,37$ & $1,31 / 0,11$ \\
\hline
\end{tabular}

Tabela IV-2 - Dados do crescimento das amostras altamente dopadas com silicio, formando o segundo conjunto, crescidas sobre substratos de GaAs; os mimeros impares correspondem aos substratos (001), e os pares aos (311)A. 
As medidas de efeito Hall mostraram que os portadores possuíam uma carga positiva, comprovando a boa escolha das condições de crescimento. Pode-se observar também que, no primeiro conjunto, a densidade de portadores dos dois tipos de amostra é da mesma ordem de grandeza, indicando que conseguimos uma ionização quase total dos átomos de dopante. A figura IV-5 mostra que a dependência do gráfico é linear e que os dois conjuntos, que foram crescidos com vários meses de intervalo, são reprodutíveis. O maior espalhamento dos dados do segundo conjunto foi causado por problemas de contatos de qualidade pior que no primeiro caso. Uma outra característica desta curva é que, ao contrário da dopagem do tipo n, a concentração dos portadores não satura para os altos fluxos de dopante, indicando uma ausência de compensação. Para o último ponto desta curva, a temperatura do forno de silício foi levada até seu extremo, $1410^{\circ} \mathrm{C}$, que é a temperatura de fusão do elemento. Como a célula é orientada para baixo, aumentar mais a temperatura poderia ser muito arriscado, pois o material poderia se desprender das paredes do cadinho e cair para dentro da câmara. $O$ único modo de obterem-se concentrações mais elevadas é usando duas células de silicio ou diminuindo a taxa de crescimento das camadas durante a evaporação do dopante.

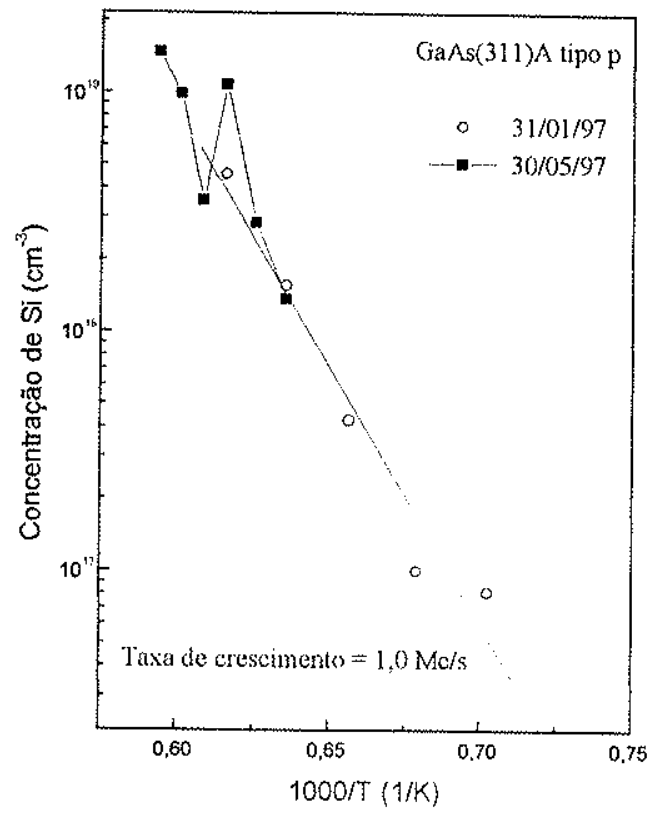

(a)

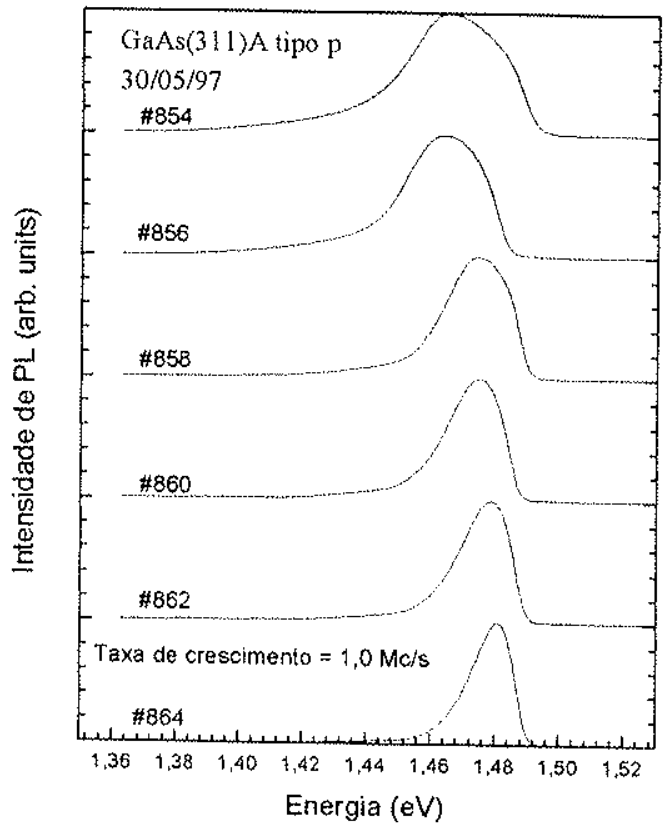

(b)

Figura $\mathrm{W}-5$ - Medidas de efeiro Hall (300K) e de fotoluminescencia $(1,4 K)$ realizadas sobre os comjumos de amostras de (GaAs(31)): Si variando-se a temperatura da célula de Si; (a)concentração de buracos em função de IT (T é a temperatura do forno de silicio); (b)espectros de fotoluminescència das amostras altamente dopadas.

Uma outra maneira de testar a qualidade da dopagem de uma estrutura cristalina é medindo a mobilidade $\mu$ dos portadores. Este parâmetro corresponde intuitivamente à "facilidade" com a qual os portadores se deslocam dentro do cristal. Ele fornece uma 
informação qualitativa sobre a qualidade cristalina do material hospedeiro que foi dopado, assim como sobre sua pureza, e pode ser obtido a partir do coeficiente de Hall:

$$
\mu_{y j}=R_{H} / t R_{s}
$$

onde

$$
R_{s}=G \pi / \ln 2\left[R_{A B, C D}+R_{B C, D A}\right]
$$

é a resistência superficial da amostra, sendo que $R_{A B, C D}$ e $R_{B C, D A}$ são respectivamente a resistência medida quando a corrente é injetada entre os contatos $A$ e $B$ e a voltagem é detectada entre $C$ e $D$, e quando a corrente é injetada entre o contatos $B$ e $C$ e a voltagem é lida entre os contatos $D$ e $A$. $G$ é um fator da ordem da unidade que depende da razão entre $R_{A B, C D}$ e $R_{B C, D A}$. Os valores experimentais de mobilidade encontrados para os dois conjuntos estão também relacionados nas tabelas IV-1 e IV-2. Normalmente, a tendência é obterem-se valores crescentes da mobilidade para valores decrescentes da concentração, pois, neste caso, o espalhamento coulombiano pelas impurezas ionizadas é menor. Esta tendência é encontrada em nossos dados cujos altos valores de mobilidade, compatíveis com os da literatura, demonstram a alta qualidade das amostras. Nesta altura três comentários podem ser feitos. O valor de concentração da amostra \#680 não ficou alinhado com os outros na Figura IV-5a, por razões aparentes de compensação, já que sua mobilidade, que deveria ser a mais alta, é na verdade a mais baixa. Isto pode ser explicado por uma eventual compensação nesta técnica de dopagem quando a concentração for tão baixa, ou por um problema de contato. O segundo comentário a se fazer é que, apesar das amostras \#853, \#855, \#857 apresentarem valores próximos da concentração de portadores, os valores da mobilidade mostram que a amostra 857 é de melhor qualidade, já que nas outras a mobilidade começou a diminuir em razão da incorporação simultânea do dopante no sítio do arsênio. Finalmente, percebe-se que a mobilidade dos buracos é sempre muito menor que a dos elétrons, devido à diferença de massa dos dois tipos de portadores.

Medidas de fotoluminescência foram realizadas sobre o segundo conjunto e são apresentadas na Figura IV-5b. Observa-se a presença de uma banda larga abaixo do gap, típica da formação de um gás tridimensional de buracos, que vai se deslocando para os valores de baixa energia a medida que a concentração aumenta.

Em muitos casos, necessita-se, para a fabricação de um dispositivo eletrônico, dos dois tipos de dopagem na mesma amostra. Os substratos (311)A oferecem esta possibilidade, já que o tipo de portador presente na camada dopada pode ser mudado com as condições de crescimento. A baixa temperatura e alto fluxo, o silício é incorporado preferencialmente no sítio do gálio. 
Todavia, a alta temperatura (acima de $500^{\circ} \mathrm{C}$ ) e baixa razão de fluxos V/III (entre 1 e 3), ele é incorporado no sítio do arsênio, mudando o caráter da camada. Portanto, técnicas de crescimento envolvendo a variação destes dois parâmetros podem ser empregadas para obterem-se os dois tipos de portadores na mesma amostra. Mudar a temperatura do substrato não é muito aconselhado, pois, a baixa temperatura, a qualidade cristalina é prejudicada, e a inércia térmica do forno da amostra deixa o processo muito demorado. A mudança do fluxo de arsênio é muito mais fácil, principalmente quando um cracker de arsênio é disponível na câmara. O mesmo efeito pode ser obtido com duas células convencionais de arsênio, sendo que para mudar o tipo de dopagem usa-se uma célula ou as duas simultaneamente.

O conjunto de dados experimentais apresentados nesta seção demonstra, sem ambigüidade nenhuma, que esta técnica é viável para produzir amostras com dopagem do tipo $\mathrm{p}$ e que dominamos perfeitamente todos os parâmetros necessários a sua realização. É a primeira vez que este método é empregado no Brasil para substituir o berilio.

\section{IV.3.2.2 - Substratos (001)}

Como os substratos (001) são os mais usados para a fabricação de dispositivos, tentamos dopá-los também com silício para obterem-se camadas do tipo p. Esta decisão foi baseada sobre o fato que isto era possivel no caso de substratos (311)A graças à presença das bordas dos terraços terminados com átomos de gálio possuindo uma única ligação pendente, favorecendo assim a incorporação do dopante em vez da molécula tetramérica de arsênio que precisa ser dissociada. Tentamos então a evaporação de silício durante o crescimento de uma camada de GaAs apresentando uma superfície rica em gálio. Neste caso, existe uma maior população de átomos de gálio na superfície que poderia favorecer a incorporação do dopante no sítio do arsênio. Isto foi realizado usando-se duas células de gálio e uma célula de arsênio. $O$ crescimento foi iniciado com uma única célula de gálio calibrada para produzir um fluxo equivalente a uma taxa de $1,0 \mu \mathrm{m} / \mathrm{h}$. O fluxo de arsênio foi estabelecido para emitir a quantidade necessária de moléculas de maneira a sempre manter a reconstrução $2 \times 4$ durante o crescimento com esta célula. De repente, a segunda célula de gálio, também calibrada com uma taxa da ordem de $1,0 \mu \mathrm{m} / \mathrm{h}$, foi aberta, mudando o padrão de reconstrução de $2 \times 4$ para $4 \times 2$, típico de uma superfície rica em gálio. Junto com a abertura da segunda célula de gálio, iniciamos a evaporação de silício. Desta maneira, uma camada dopada de 1,0 $\mu \mathrm{m}$ foi crescida. Medidas de efeito Hall mostraram que a camada apresentava um caráter do tipo $\mathrm{n}$, com uma concentração de portadores e uma mobilidade ligeiramente mais baixas (30\%) que no caso de uma superficie rica 
em arsênio, provavelmente resultando da incorporação do dopante nos dois sítios possíveis ou formando um complexo. Uma amostra crescida nestas condições não apresenta nenhum interesse, pois além de suas características elétricas inferiores, ela possui uma superfície extremamente rugosa devido ao crescimento na presença de uma reconstrução $4 \times 2$. Este procedimento já tinha sido adotado por Cho em 1971 e levou às mesmas conclusões ${ }^{88}$.

Optamos então por uma situação mais extrema. O crescimento foi iniciado em condições normais (superfície rica em arsênio com reconstrução $(2 \times 4)$ ) e terminado normalmente, fechando-se o obturador da célula de gálio. Repentinamente, a célula de arsênio foi fechada, e, dois segundos depois, as células de gálio e silício foram abertas para evaporar o equivalente a dez monocamadas de gálio, transformando o padrão de difração em $4 \times 2$ (difuso). Finalmente,

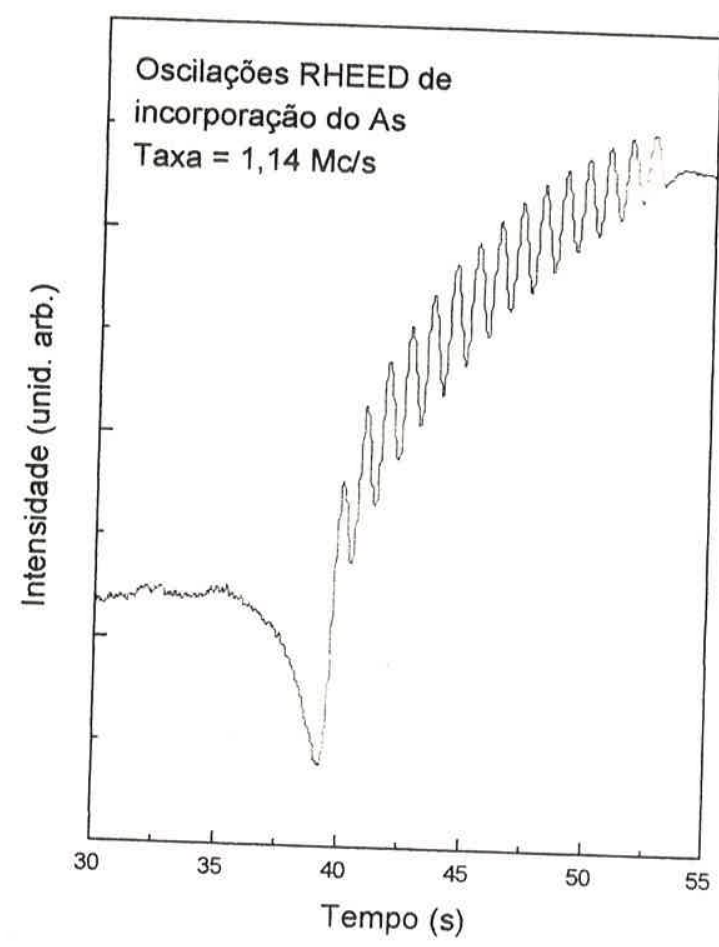

Figura IV-6 - Oscilações da intensidade luminosa do feixe especular devido à incorporação de arsênio por 15 camadas de gálio previamente depositadas sobre a superficie de GaAs(100); a célula de gálio ficou aberta até o tempo $t=37$ s, provocando uma reconstrução $4 \times 2 e$ uma baixa intensidade do feixe especular; no tempo $t=37 \mathrm{~s}$, o obturador da célula de gálio foi fechado e o da célula de arsênio aberto; as oscilações são provocadas pela incorporação de arsênio dentro da camada de gálio puro, formando quinze camadas de GaAs, como demonstra o mimero de oscilações.

estas duas células foram fechadas e o obturador da célula de arsênio aberto novamente. As dez camadas de gálio anteriormente depositadas consumiram todo o arsênio incidindo na superfície para constituírem dez camadas completas de GaAs. Neste momento, o arsênio parou de ser incorporado e a reconstrução voltou a ser do tipo $2 \times 4$. Durante a incidência do arsênio sobre a superfície rica em gálio, existe uma oscilação muito clara da intensidade do feixe especular relacionada com a incorporação do elemento tetramérico na rede cristalina.

Para evitar a evaporação pronunciada do arsênio durante a deposição das camadas de gálio, a temperatura do substrato precisa ser abaixada em torno de $520^{\circ} \mathrm{C}$. Esta técnica é as vezes utilizada para calibrar o fluxo de arsênio. Todavia, otimizamos a temperatura de operação para 
observarmos o maior número de oscilações e demonstrar que as dez camadas de gálio depositadas provocavam dez oscilações durante a recuperação da superfície. Este ciclo pode ser repetido indefinidamente, já que o estado inicial e final é sempre uma superfície estabilizada em arsênio de boa qualidade, como pode ser visto pelo padrão de difração presente na tela do sistema RHEED. A amostra $\$ 920$ foi crescida desta maneira, alternando 179 ciclos de 10 camadas de átomos de gálio com paradas de quinze segundos de exposição ao fluxo de arsênio para formar as camadas de GaAs. A estrutura dopada possui então uma espessura da ordem de $0,5 \mu \mathrm{m}$.

As medidas de efeito Hall mostraram que esta amostra era altamente dopada, apresentando um caráter do tipo p como desejado. O número de portadores $\left(1,2 \times 10^{18} \mathrm{~cm}^{-3}\right.$ para uma taxa de crescimento de $1,6 \mu \mathrm{m} / \mathrm{h}$ e uma temperatura da célula de silício de $1390^{\circ} \mathrm{C}$ ) representa $60 \%$ da quantidade total de átomos de silício que foi incorporada nas camadas, mostrando que só uma parte do dopante se tornou eletricamente ativo.

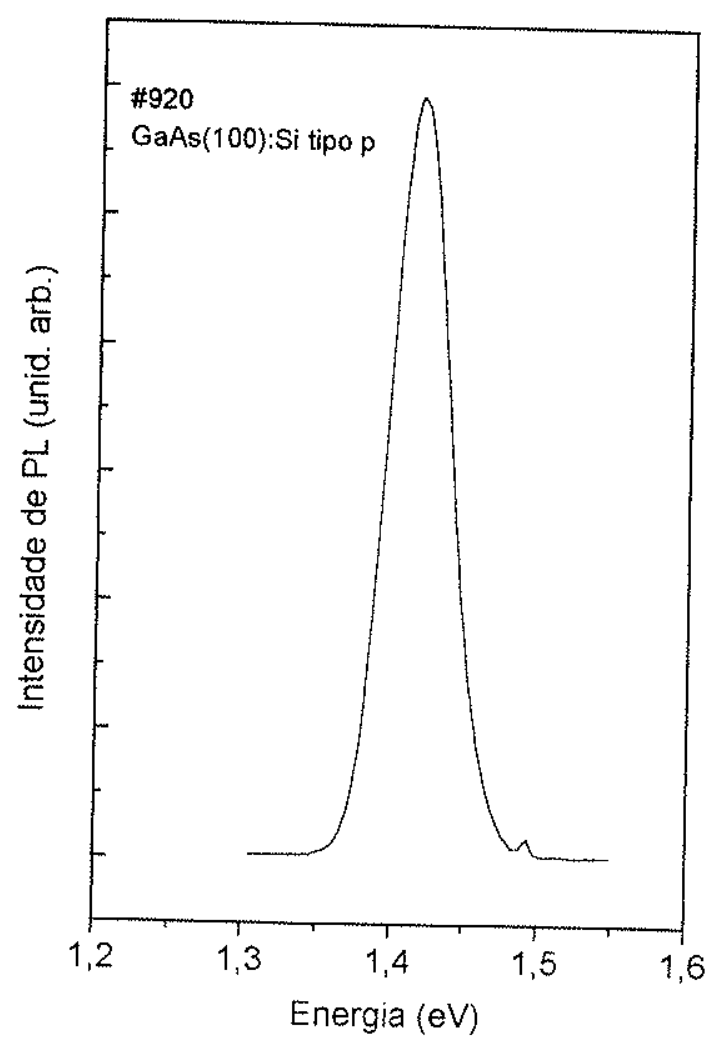

Figura $I V-7$ - Espectro de fotoluminescência $\left(I, 4 K^{\prime}\right) d a$ amostra \#920 de GaAs(001):Si mostrando uma banda intensa a $1,42 \mathrm{eV}$, o mesmo valor da energia que para as amostras altamente dopadas da Figura IV-3a onde o efeito de compensação foi relacionado com a formação de um complexo $S_{i_{A s}} V_{G a}$; o pico de menor intensidade corresponde a transiçấo da banda de conduçấo para o nivel aceitador de carbono $(1,493 \mathrm{eV})$.

A única maneira de produzir uma amostra de GaAs dopada com silício possuindo um caráter $\dot{p}$ é pela incorporação do dopante no sítio do arsênio, já que no sítio do gálio ou em posição intersticial, o silício se comporta como um doador. A presença de vacâncias e de defeitos do tipo antisítio (um átomo de gálio ocupando o lugar de um átomo de arsênio, ou vice 
e versa) costuma criar estados com níveis de energia profundos, o que é incompatível com a alta densidade de buracos observada, que é relacionada com a presença de um nível raso.

Portanto, nossa interpretação do mecanismo de crescimento é a seguinte: durante a deposição das camadas de gálio, um padrão $4 \times 2$ difuso é observado, indicando uma superfície com caráter cristalino e rica em gálio. Foi sugerido ${ }^{115}$ que, durante a evaporação dos átomos de gálio, uma única camada de gálio era formada (produzindo o padrão $4 \times 2$ ), enquanto que o restante do material seria acumulado na forma de gotas líquidas espalhadas sobre o substrato em razão da alta tensão superficial do material. Quando o fluxo de arsênio é incidido sobre a amostra, as moléculas tetraméricas são todas incorporadas (com o coeficiente máximo 0,5) dando origem à primeira oscilação da intensidade luminosa do feixe especular. A medida que o gálio superficial está sendo consumido, uma nova camada atômica é providenciada pelas gotas líquidas (atuando como reservatórios), que será também consumida pelo fluxo incidente de arsênio, gerando uma segunda oscilação. Este processo se repete até que todo o gálio tenha se esgotado. Neste momento, a superfície se torna rica em arsênio (que torna a ter um coeficiente de colagem nulo) e produz um padrão de difração $2 \times 4$. O silício, que foi depositado simultaneamente com o gálio, deve estar presente tanto nas gotas quanto na camada bidimensional. Todavia, para que ele esteja incorporado no sítio do arsênio, a maior parte do dopante deve estar na verdade acima da camada de gálio (i.e. ocupando o sítio do arsênio), pois se estivesse dentro da camada ocuparia o sítio do gálio. Este tipo de formação das camadas não é tão eficiente quanto o modo normal de crescimento e deve certamente criar numerosos defeitos estruturais, principalmente do tipo antisítio e vacância de gálio. As vacâncias são necessárias para formar o complexo Si-X (e justificar o caráter $\mathrm{p}$ da amostra), enquanto que os defeito do tipo antisítio são centros profundos negativos que podem compensar o sistema (como mostrado pela atividade elétrica de $30 \%)$. Isto é confirmado pelo baixo valor da mobilidade $\left(2,6 \mathrm{~cm}^{2} / \mathrm{Vs}\right)$, indicando provavelmente uma má qualidade do cristal ou um efeito de compensação. O método pode ser melhorado otimizando os parâmetros de crescimento, principalmente o número de camadas de gálio depositadas e a temperatura do substrato, durante a deposição é a recuperação da superfície. Se isto for confirmado, esta técnica inédita de dopagem poderá ser usada, em conjunto com a técnica habitual, para obterem-se os dois tipos de portadores numa mesma amostra cortada no plano (001), empregando um único dopante.

$\mathrm{O}$ espectro de fotoluminescência da amostra \#920 mostra uma banda a 1,42 eV, localizada na mesma energia que a banda apresentada pelas amostras de GaAs(001):Si do tipo n altamente dopadas. Podemos assumir então, que a origem seja a mesma, um complexo do tipo 
aceitador composto pela incorporação de Si no sítio de As mais uma vacância de Ga. Esse resultado confirma nossas esperanças em relação ao futuro desse método porém, alguns pontos de verão ser ainda investigados, como a dependência da concentração de buracos com a concentração de Si, maneiras de controlar e reduzir as vacâncias de Ga durante o crescimento, e medidas Raman poderão fornecer a exata localização na rede dos átomos de Si e analisar a origem do efeito de compensação. 


\section{V - Camadas epitaxiais para dispositivos eletrônicos e optoeletrônicos}

\section{V.1 - Camadas com alta mobilidade eletrônica}

No capítulo anterior, estudamos várias técnicas de dopagem homogênea das camadas de GaAs. Todas elas tinham como objetivo a dopagem de uma camada espessa onde os portadores de carga ocupavam o mesmo espaço físico que as impurezas ionizadas de onde eram originários. Neste tipo de estrutura, os valores da mobilidade diminuem com o aumento da concentração dos portadores, sendo que acima de $10^{18} \mathrm{~cm}^{-3}$, mobilidades superiores a $1500 \mathrm{~cm}^{2} / \mathrm{Vs}$ são dificilmente alcançáveis em razão da interação coulombiana entre os portadores e as impurezas ionizadas. Em 1978, Dingle ${ }^{116}$ imaginou uma estrutura onde os portadores podiam ser separados dos átomos do dopante e ocupar um espaço físico diferente. Nesta estrutura, a dopagem era realizada numa camada de material com gap maior, separada fisicamente da região ativa do dispositivo, composta por uma camada de material com gap menor. Tratava-se na verdade de

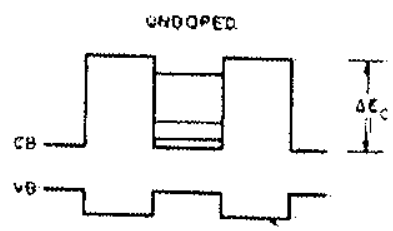

OWI FORMEY DOPEO

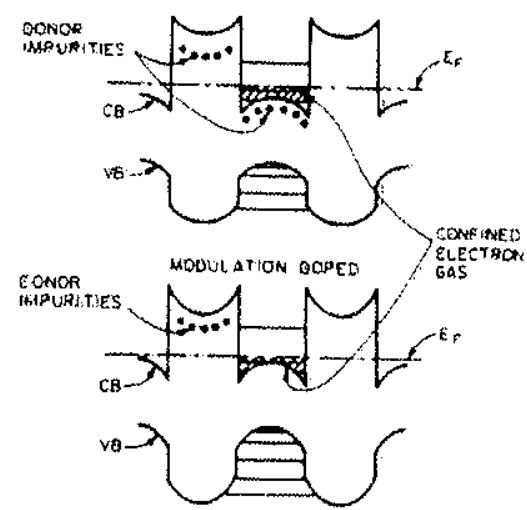

Figura $V-1$ - Diagramas de bandas de energia para amostras de poços quânticos miltiplos não dopados, com dopagem homogênea e dopagem modulada ${ }^{\prime \prime \sigma}$; os pontos pretos representam o nivel das impurezas doadoras que são presentes unicamente na barreira no caso da dopagem modulada; o gás de elétrons se encontra no material de menor gap que forma o poço.

uma estrutura de múltiplos poços quânticos onde a dopagem era realizada na barreira unicamente, em vez de ser na amostra inteira. Desta maneira, os portadores são transferidos para a camada ativa (na interface entre os dois materiais), de excelente qualidade cristalina e isenta de impurezas (intencionais), onde alcançavam altíssimas mobilidades. Este tipo de dopagem deu 
o nome à técnica de modulação de dopagem, onde os átomos do dopante são concentrados em algumas regiões da amostra, ao contrário da técnica de dopagem homogênea, até então utilizada.

Vários dispositivos foram elaborados a partir da idéia original de Dingle, o mais conhecido e popular sendo o transistor de alta mobilidade eletrônica, HEMT ${ }^{117}$ (high electronmobility transistor). HEMTs de $\mathrm{GaAs} / \mathrm{Al}_{\mathrm{x}} \mathrm{Ga}_{1-\mathrm{x}} \mathrm{As}$ são usados em numerosas aplicações onde altas freqüências de funcionamento são necessárias, e são atualmente os componentes mais produzidos industrialmente pela técnica MBE devido à superioridade incontestável do GaAs em relação ao silício nesta área. Em nosso caso, sua característica de alta mobilidade pode ser usada como teste da qualidade das amostras crescidas no sistema. A obtenção de altas mobilidades será uma conseqüência da alta pureza das camadas produzidas, da boa qualidade do vácuo na câmara e da alta cristalinidade da amostra.

A Figura V-2a mostra o caso mais simples de uma estrutura HEMT, como será adotada neste trabalho. Trata-se de uma camada espessa (buffer) de GaAs, acima da qual serão crescidas uma camada não dopada de AlGaAs, de largura variável, chamada de espaçador (spacer layer), a região de AlGaAs dopada com silicio, e finalmente a camada superior de GaAs, dopada também com silício, destinada a proteger a camada de AlGaAs e realizar os contatos elétricos. $O$ diagrama de bandas de energia próximo à heterointerface AlGaAs/GaAs é ilustrado na Figura V2b. O canal de alta mobilidade é formado na interface da heterojunção entre as camadas de AlGaAs e GaAs não dopadas, com o suprimento de elétrons sendo fornecido pela camada de AlGaAs dopada. Essa última é separada do canal pela camada de AlGaAs não dopada para minimizar a difusão dos átomos do dopante para dentro da camada de GaAs durante o crescimento, o que teria um efeito negativo sobre os valores da mobilidade. Nesta configuração, os niveis de energia das impurezas doadoras no AlGaAs permanecem acima do fundo da banda de condução do GaAs, fazendo com que os elétrons sejam difundidos para a camada de GaAs não dopada. Os portadores, são atraídos na região de menor gap, onde são confinados na interface, devido à interação coulombiana com as impurezas ionizadas, e formam um gás bidimensional de elétrons (2-dimensional electron gas - 2DEG). O campo elétrico resultante deforma a banda na heterointerface, criando um poço de potencial quase triangular, confinando os elétrons e blindando as impurezas ionizadas na camada de AlGaAs dopada. A alta temperatura, o principal mecanismo de espalhamento dos portadores é a interação com os fônons, enquanto que a baixa temperatura, a principal causa da limitação da mobilidade é o espalhamento por impurezas ionizadas, tanto na camada dopada de AlGaAs quanto na camada de GaAs não dopada (provenientes, neste último caso, de impurezas do gás residual ou da 
superficie do substrato).

Variando a espessura $d$ da camada espaçadora, pode-se controlar a concentração de portadores no poço. Quando ela for maior, obtém-se um aumento ${ }^{118}$ substancial da mobilidade devido à redução do espalhamento pelas impurezas ionizadas na camada dopada de AlGaAs, principalmente a baixa temperatura.

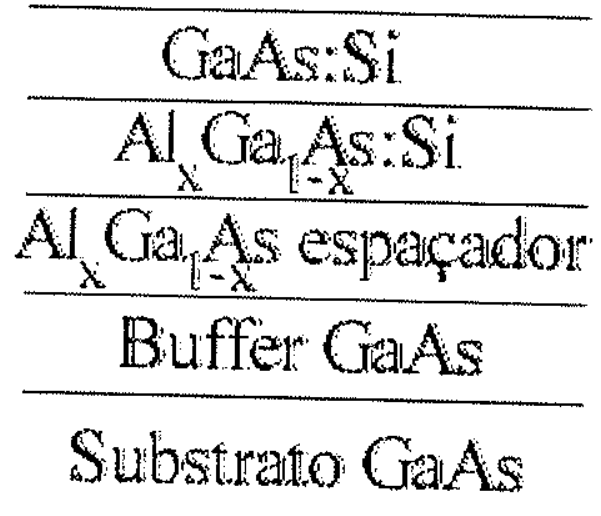

(a)

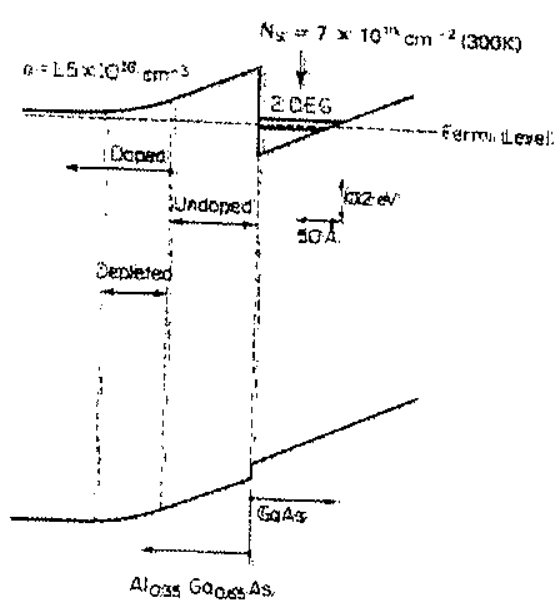

(b)

Figura $V-2$-... (a)esquema das estruturas do tipo HEMT crescidas em nosso sistema; (b)diagrama de bandas de energia próximo à interface $A l_{x} G a_{/ x} A s / G a A s^{l 19}$; neste tipo de estrutura, o gás de elétrons é bidimensional $e$ confinado mum poço de potencial estreito criado na interface entre os dois materiais.

Algumas estruturas HEMT foram crescidas, seguindo o modelo da Figura V-2a, sobre substratos de GaAs (100) semi-isolantes, variando-se a largura da camada espaçadora. Para todas as amostras, a espessura da camada buffer, da camada de AIGaAs dopada e da camada superior dopada foram respectivamente de $1,5 \mu \mathrm{m}, 800 \AA$ e $200 \AA$, sendo que a concentração nominal dos átomos de silício nas duas camadas dopadas foi de $2,0 \times 10^{18} \mathrm{~cm}^{-3}$. A temperatura de crescimento foi fixada em $580^{\circ} \mathrm{C}$, para a estrutura inteira, de maneira a limitar a difusão dos átomos do dopante, e interrupções de crescimento de 40 s foram realizadas em todas as interfaces. Taxas de crescimento em torno de $0,7 \mu \mathrm{m} / \mathrm{h}$ e $1,0 \mu \mathrm{m} / \mathrm{h}$ foram usadas respectivamente para as ligas GaAs e $\mathrm{Al}_{x} \mathrm{Ga}_{1 \times x} \mathrm{As}$. A concentração $x$ de aluminio na liga de $\mathrm{Al}_{x} \mathrm{Ga}_{1-x}$ As esteve em torno de $30 \%$ para todas as amostras.

A Tabela V-1 mostra alguns parâmetros do crescimento das amostras realizadas segundo a estrutura ilustrada na Figura V-2a. Os resultados experimentais de densidade de portadores e mobilidade não foram obtidos por medidas de efeito Hall, já que nestes sistemas os portadores não estão mais confinados numa camada tridimensional determinada pelo crescimento da camada dopada, mas sim num poço triangular, quase bidimensional, localizado na interface 
entre os dois materiais. Nestas condições, precisamse recorrer às medidas mais sofisticadas e demoradas de efeito Shubnikov-de Haas, que necessitam a medida da resistividade elétrica da

\begin{tabular}{cccccc}
\hline Amostra & $\begin{array}{c}\text { Orientação do } \\
\text { substrato }\end{array}$ & $\begin{array}{c}\text { Largura do } \\
\text { espaçador }(\AA)\end{array}$ & $\begin{array}{c}\mathrm{x} \text { do } \\
\text { aluminio }\end{array}$ & $\begin{array}{c}\text { Mobilidade } \\
\text { a 4K } \\
\left(10^{4} \mathrm{~cm}^{2} / \mathrm{Vs}\right)\end{array}$ & $\begin{array}{c}\text { Concentração } \\
\text { de elétrons }\left(10^{11}\right. \\
\left.\mathrm{cm}^{-2}\right)\end{array}$ \\
\hline$\# 842$ & $(100)$ & 150 & 0,30 & 60 & 4,2 \\
$\# 870$ & $(100)$ & 250 & 0,29 & 6,0 & 3 \\
$\# 871$ & $(100)$ & 350 & 0,29 & 2,5 & 1,8 \\
\hline
\end{tabular}

Tabela V-1 - Parâmetros de crescimento e resultados experimentais das estruturas HEMTs de GaAs/Al $G a_{1-x} A$ s

amostra em função do campo magnético aplicado perpendicularmente à superfície. Estas medidas foram realizadas em nosso grupo, pelo Professor Gusev, dentro de uma bobina supercondutora resfriada com hélio líquido. Este efeito de oscilação da resistividade em função do campo magnético é baseado numa teoria complexa que não convém descrever neste trabalho. Todavia, precisa-se saber que o espectro de Fourier destas oscilações revela a presença de várias freqüências características que são relacionadas com o número de bandas de energia populadas. A população de cada banda pode ser encontrada, o que fornece a densidade total de portadores. Esta técnica fornece também uma estimativa da mobilidade dos portadores dentro do poço de potencial

A amostra \#842 apresentou uma mobilidade da ordem de $600.000,00 \mathrm{~cm}^{2} / \mathrm{Vs}$ a $4 \mathrm{~K}$, o que representa a mais alta mobilidade já obtida numa amostra de GaAs crescida por MBE no Brasil. Este resultado demonstra que a qualidade da camada de GaAs é excelente. A mobilidade das outras amostras, crescidas nas mesmas condições mas com um espaçador maior, foi muito mais baixa, ao contrário do que se esperava. Isto pode ser explicado por uma má qualidade da camada de AlGaAs. De fato, se esta camada estiver contaminada ou apresentar uma alta densidade de centros profundos, seu alargamento pode aumentar a captura dos elétrons pelos defeitos que passam a possuir um estado final carregado e interagem com os portadores na interface, diminuindo dramaticamente a mobilidade. Esta má qualidade da liga de AlGaAs não foi uma grande surpresa, já que no decorrer do ano de 1997, a câmara de crescimento foi aberta seis vezes para realizar o conserto de várias partes mecânicas que apresentaram problemas inesperados. Como não dispúnhamos, na época, das cargas de material e de cadinhos novos, os mesmos foram usados após cada abertura. Isto não é aconselhado, pois impossibilita a limpeza das cargas e a desgaseificação completa dos cadinhos, o que prejudica consideravelmente a pureza das camadas epitaxiais. Como pôde ser constatado pelo excelente resultado da amostra \#842, as camadas de GaAs não foram muito afetadas, pois a carga pôde ser desgaseificada a 50 
ou $100^{\circ} \mathrm{C}$ acima da temperatura normal de uso, sem problema algum. O problema é muito mais sério com a célula de alumínio, já que ela precisa ser desgaseificada a mais alta temperatura, $\mathrm{e}$ durante mais tempo, em razão da presença de uma camada espessa de óxido sobre a carga e as paredes do cadinho. Como parte do material se acumula na borda do cadinho, onde a temperatura é sempre mais baixa, esta região não é desgaseificada eficientemente e a contaminação persiste. Pôde-se constatar, após as numerosas aberturas, a presença de uma camada de cor verde e marrom na borda do cadinho, devido à oxidação do material.

Portanto, com um sistema MBE limpo e equipado com cargas e cadinhos novos, acreditamos que valores de mobilidade muito mais altos possam ser obtidos num futuro próximo. Além disso, nenhum parâmetro de crescimento da estrutura foi otimizado, como por exemplo a largura do espaçador, o tempo de interrupção nas interfaces, a rugosidade da interface e a temperatura de crescimento da camada de AlGaAs.

Outras amostras de estrutura HEMT foram crescidas, para completar nossa pesquisa sobre estes dispositivos, mas não puderam ser caracterizadas em razão da falta de hélio líquido no Instituto nos últimos meses. Crescemos amostras parecidas com a \#842 sobre substratos (311)A para analisar a influência desta estrutura sobre os valores da mobilidade dos buracos, já que elas são geralmente muito baixas no caso de sistemas dopados homogeneamente do tipo $\mathrm{p}$ (da ordem de $100 \mathrm{~cm}^{2} / \mathrm{Vs}$ ). Estruturas $\delta$-HEMT, onde a camada de AlGaAs dopada homogeneamente foi substituída por uma camada dopada planarmente, foram também obtidas. Este tipo de dopagem é muito importante ${ }^{120}$, pois limita a espessura da camada dopada a alguns planos atômicos, o que diminui o tamanho vertical do dispositivo e melhora algumas de suas características. Esta dopagem planar (também chamada de dopagem $\delta$ ) é realizada parando-se o crescimento do AlGaAs e evaporando o silício sobre a superficie da amostra durante um certo tempo $^{121}$. Em seguida, o crescimento pode ser retomado normalmente, confinando o dopante na última camada crescida antes da interrupção. Todavia, na prática, a distribuição espacial das impurezas é mais larga devido à difusão durante o crescimento.

\section{V.2 - Espelhos de Bragg}

A técnica $\mathrm{MBE}$ começou a ser empregada nos anos 70 para a elaboração de dispositivos eletrônicos (como o HEMT) e optoeletrônicos devido a seu controle preciso das dopagens, das ligas e das interfaces entre materiais de natureza diferente. Diodos de emissão de luz (LED, light emitting diode) e diodos $\operatorname{laser}^{122}$ são o fruto desta tecnologia e já são freqüentemente encontrados no mercado. O princípio básico destes elementos ópticos é a presença de uma 
junção p-n polarizada diretamente, onde os portadores minoritários recombinam radiativamente (pelo processo de emissão espontânea ou estimulada, dependendo do tipo de dispositivo) com os portadores majoritários dentro da zona de depleção na interface. O LED é o sistema mais simples, pois não precisa de nenhuma cavidade óptica para funcionar, mas possui uma potência luminosa baixa, um espectro largo (300-400 $\AA$ ), uma radiação incoerente, e só pode ser modulado com freqüências inferiores ao gigaHertz. Todavia, devido a seu baixo custo de produção, ele é um dos componentes semicondutores mais utilizados em optoeletrônica, principalmente em displays luminosos e como fonte luminosa para comunicações ópticas quando sinais coerentes não são necessários. A estrutura de um diodo laser é muito parecida com a de um LED, mas uma cavidade óptica é necessária para aumentar a densidade de fótons na região ativa e iniciar o processo de emissão estimulada que providencia um sinal luminoso de maior intensidade, coerente, de maior pureza espectral e possibilitando modulações com freqüencias até 1000 vezes superiores. O tipo mais comum de diodo laser é baseado numa cavidade de Fabry-Pérot fabricada pela clivagem do cristal perpendicularmente ao plano das camadas epitaxiais, e a emissão luminosa é realizada pelas bordas da amostra (por isso é chamado laser a emissão lateral, edge-emission laser). Devido à baixa refletividade da interface semicondutor/ar (em torno de $30 \%$ ), a eficiência quântica externa (a razão entre o número de pares elétron/buraco injetados na junção e o número de fótons oriundos do dispositivo) deste tipo de estrutura é bastante baixa, o que impõe um tamanho inferior limite da ordem de $100 \mu \mathrm{m}$ e aumenta consideravelmente a corrente elétrica necessária para iniciar o efeito laser (limiar de corrente, threshold current).

Mais recentemente, um novo tipo de laser (o de emissão superficial com cavidade vertical, vertical-cavity surface-emitting laser, VCSEL) ${ }^{123,124}$, apareceu no mercado devido à possibilidade de fabricação in situ (dentro do sistema MBE) de cavidades de Fabry-Pérot de alta qualidade. Esta cavidade é cercada por dois espelhos de alta refletividade, os DBRs (distributed Bragg reflectors), que são constituídos por dezenas de pares de camadas de dois materiais semicondutores com índices de refração diferentes e possuindo uma largura bem definida. Com este tipo de estrutura, refletividades maiores que $99 \%$ são possiveis, o que aumenta drasticamente a eficiência quântica e possibilita a fabricação de dispositivos de menor dimensão (da ordem do micrômetro) ${ }^{125}$, possuindo portanto um limiar de corrente muito baixo.

O principal problema na construção de um laser a cavidade vertical é a otimização dos parâmetros de crescimento dos espelhos de alta reflexão. Trata-se basicamente de camadas alternadas de materiais com índices de refração diferentes ${ }^{126}$, possuindo uma largura de $\lambda / 4 n$ 
(por isso são chamadas espelhos quarto de onda), onde $\lambda$ é o comprimento de onda para o qual se deseja a maior refletividade possível (em nosso caso o comprimento de onda de emissão do laser) e $n$ o índice de refração do material. Como o índice de refração dos materiais GaAs e AlAs é respectivamente 3,52 e 2,95 (na verdade eles dependem da temperatura e do comprimento de onda considerado), necessita-se de um grande número de camadas para obter uma alta reflexão. Isto implica que o crescimento de uma estrutura laser completa possa levar até 20 horas, dependendo das especificações e dos sistemas de crescimento. Durante este tempo, qualquer variação dos parâmetros de crescimento pode prejudicar o desempenho final do dispositivo, o que requer um domínio completo do sistema e das condições de crescimento.

Nesse trabalho, estudamos o crescimento de espelhos de alta reflexão que foram caracterizados quanto a sua refletividade e qualidade das camadas crescidas. Obtivemos uma refletividade de $96 \%$ para 10 pares de AlAs/GaAs, valor que constitui o limite teórico para os parâmetros adotados neste caso.

O primeiro conjunto de amostras foi elaborado para obter-se um máximo de reflexão em $\lambda=810 \mathrm{~nm}$. A largura das camadas foi calculada por

$$
\frac{\lambda}{4 n}
$$

Usamos um índice de refração de 2,9 e 3,5 para o AlAs e GaAs respectivamente. No caso da liga $\mathrm{Al}_{x} \mathrm{Ga}_{1 \times \mathrm{x}} \mathrm{As}, n$ pode ser calculado por

$$
n=n_{\text {GaAs }}-x\left(n_{\text {GaAss }}-n_{\text {AIAS }}\right) \text {. }
$$

Foram crescidas quatro amostras variando-se as ligas das camadas. OS DBRs foram constituídos por dez pares de camadas alternadas de $\mathrm{Al}_{x} \mathrm{Ga}_{1-\mathrm{x}} \mathrm{As}(0,3 \leq \mathrm{x} \leq 1,0)$ e $\mathrm{Al}_{\mathrm{y}} \mathrm{Ga}_{1-\mathrm{y}} \mathrm{As}$ $(y=0$ ou 0,29). A estrutura das amostras é esquematizada na Figura V-3. As amostras foram preparadas segundo os procedimentos descritos no item $I .5 .2$ e crescidas sobre substratos de GaAs (100):Cr. Duas super-redes de $500 \AA$ de AlAs/GaAs (20/30 $\AA$ ) foram crescidas antes e depois do crescimento da camada buffer de GaAs (usamos as super-redes para evitar a migração do cromo contido no substrato). A pressão equivalente do fluxo de $\mathrm{As}_{4}$ foi fixada em torno de $10^{-5}$ Torr para todas as amostras, que foram crescidas à temperatura de $600^{\circ} \mathrm{C}$. Interrupções de crescimento foram utilizadas, sendo de 60 s após o crescimento das camadas de AlGaAs e GaAs e de 90s após o crescimento das camadas de AlAs (o alumínio possui um coeficiente de difusão menor que o do gálio, sendo necessário um tempo maior de interrupção no caso de altas concentrações desse material na liga). Foram adotadas velocidades de crescimento em torno de $1 \mu \mathrm{m} / \mathrm{h}$ em todas as camadas, exceto para as camadas de AlAs que foram crescidas com taxas de 
$0,6 \mu \mathrm{m} / \mathrm{h}(\# 655)$ e $0,3 \mu \mathrm{m} / \mathrm{h}(\# 656)$.

Todas as amostras foram terminadas por uma camada de GaAs pertencente ao espelho, exceto a amostra \#656 que recebeu uma camada superior de proteção (cap layer) de $100 \AA$ de GaAs sobre a última camada de AlGaAs. Todas as amostras foram constituídas por 10 pares de camadas e levaram de duas a cinco horas, cada uma, para serem crescidas. Apesar deste número

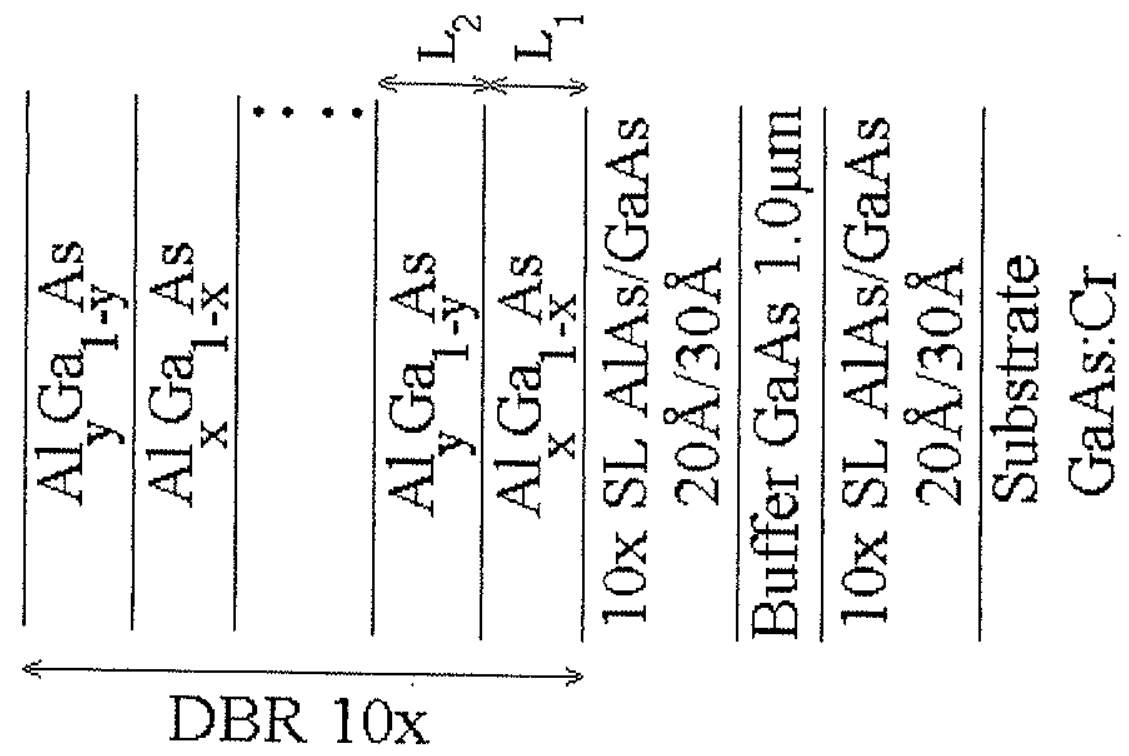

Figura V-3 - Diagrama esquemático dos espelhos de Bragg crescidos para $\lambda=810 \mathrm{~nm}$; a super-rede limita a migração dos átomos de cromo contidos no substrato; $L_{1}$ e $L_{2}$ indicam a largura da camada para cada material.

limitado de camadas não oferecer uma refletividade máxima, ele foi escolhido para minimizar o tempo total de crescimento. O padrão de difração $2 \times 4$, verificado após cada crescimento, apresentou-se com um feixe especular brilhante e bem definido (característica de uma amostra de boa qualidade) em todas as amostras, exceto para \#656. Outros detalhes do crescimento são mostrados na Tabela V-2.

\begin{tabular}{|c|c|c|}
\hline Amostra & Estrutura & $L(\AA)$ \\
\hline 653 & $\begin{array}{c}\text { GaAs } \\
\mathrm{Al}_{0,31} \mathrm{Ga}_{0,69} \mathrm{As}\end{array}$ & $\begin{array}{l}578.5 \\
609.9 \\
\end{array}$ \\
\hline 654 & $\begin{array}{c}\text { GaAs } \\
\mathrm{Al}_{0,6} \mathrm{Ga}_{0.4} \mathrm{As}\end{array}$ & $\begin{array}{l}578.5 \\
644.9 \\
\end{array}$ \\
\hline 655 & $\begin{array}{l}\text { GaAs } \\
\text { AlAs }\end{array}$ & $\begin{array}{l}578.5 \\
698.7 \\
\end{array}$ \\
\hline 656 & $\begin{array}{c}\mathrm{Al}_{0.29} \mathrm{Ga}_{0.71} \mathrm{As} \\
\mathrm{AlAs}\end{array}$ & $\begin{array}{l}609.9 \\
698.2\end{array}$ \\
\hline
\end{tabular}

Tabela V-2 - Dados do crescimento dos espelhos de Bragg para $2 . . .810 \mathrm{~mm} ;$ L é a largura das camadas em A.

Um segundo conjunto de amostras foi crescido para $\lambda=980 \mathrm{~nm}$, que é um dos mínimos 
de absorção das fibras ópticas atuais. A estrutura das amostras foi a mesma que no primeiro conjunto, exceto pelo uso de substratos de $\mathrm{GaAs}(001)$ sem cromo e pela ausência das superredes, usadas nas amostras anteriores antes e depois do crescimento da camada buffer. As temperaturas de crescimento foram de $580^{\circ} \mathrm{C}$ para o GaAs e $600^{\circ} \mathrm{C}$ para as camadas contendo alumínio, de maneira a minimizar a rugosidade desse material durante o crescimento. As interrupções de crescimento foram de $60 \mathrm{~s}$ em todas as interfaces. As taxas de crescimento utilizadas foram fixadas em torno de $1 \mu \mathrm{m} / \mathrm{h}$ para o crescimento do GaAs e AlGaAs. No crescimento do AlAs, usamos uma taxa de $0,7 \mu \mathrm{m} / \mathrm{h}$. Todas as amostras foram terminadas com uma camada de GaAs pertencente ao espelho e apresentaram um padrão de difração muito intenso após o crescimento. A Tabela V-3 mostra os detalhes do crescimento destas amostras.

Para os dois conjuntos, a calibração das taxas de crescimento das ligas foi realizada antes do crescimento de cada amostra para minimizar as variações de fluxo com o tempo. A amostra \#822 foi crescida usando-se o método de pseudo-liga no crescimento das camadas de AlGaAs. Esta técnica de crescimento é uma maneira alternativa de formar uma liga ternária. Em vez de se crescer uma camada possuindo a razão certa do número de átomos de cada espécie da família III (por exemplo $\mathrm{Al}_{\mathrm{x}} \mathrm{Ga}_{1 \times \mathrm{x}} \mathrm{As}$ ) pode-se crescer camadas finas (algumas camadas atômicas) e alternadas de AlAs e GaAs, cuja espessura é determinada pela concentração dos respectivos

\begin{tabular}{|c|c|c|}
\hline Amostra & Estrutura & $L(\AA)$ \\
\hline \multirow[b]{2}{*}{817} & GaAs & 700,0 \\
\hline & $\mathrm{Al}_{0.21} \mathrm{Ga}_{0.79} \mathrm{As}$ & 724,8 \\
\hline \multirow[b]{2}{*}{818} & $\mathrm{GaAs}$ & 700,0 \\
\hline & $\mathrm{Al}_{0,39} \mathrm{Ga}_{0,61} \mathrm{As}$ & 751,5 \\
\hline \multirow[b]{2}{*}{819} & GaAs & 700,0 \\
\hline & $\mathrm{Al}_{0.59} \mathrm{Ga}_{0.41} \mathrm{As}$ & 780,2 \\
\hline \multirow[b]{2}{*}{820} & GaAs & 700,0 \\
\hline & $\mathrm{Al}_{0.82} \mathrm{Ga}_{0.18} \mathrm{As}$ & 811,3 \\
\hline \multirow[b]{2}{*}{821} & GaAs & 700,0 \\
\hline & AlAs & 844,8 \\
\hline \multirow{3}{*}{822} & GaAs & 700,0 \\
\hline & AlAs/GaAs & \\
\hline & $(2 / 8 \mathrm{Mc})$ & 735,1 \\
\hline
\end{tabular}

Tabela $V-3$-... Dados do crescimento dos espelhos de Bragg para $\lambda . . .980 \mathrm{~mm}$; L. indica a largura das camadas em $A$; a amostra it 822 foi crescida usando-se o método de pseudo-liga.

elementos na liga desejada. Uma grande vantagem do uso desse método é a possibilidade de variação da liga durante o crescimento, sem qualquer variação da temperatura dos fornos. Desse modo, pode-se obter perfis de qualquer tipo e suavizar, se for necessário, a interface entre duas 
ligas diferentes. Esse método é muito usado no crescimento de DBRs dopados para utilização em lasers a cavidade vertical para reduzir a resistência elétrica dos espelhos de $\mathrm{Bragg}^{127,128}$, minimizando a acumulação do dopante nas interfaces. Obtivemos uma concentração de $20 \%$ de alumínio na liga ternária $\mathrm{Al}_{\mathrm{x}} \mathrm{Ga}_{1-\mathrm{x}} \mathrm{As}$ pelo crescimento de vinte e seis períodos de oito monocamadas de GaAs alternadas com duas monocamadas de AlAs. Essa amostra foi crescida para comparação com a amostra \#817 possuindo uma concentração nominal de alumínio de $21 \%$ na liga de $\mathrm{Al}_{\mathrm{x}} \mathrm{Ga}_{1-\mathrm{x}} \mathrm{As}$.

Todas as amostras foram caracterizadas pela técnica de raios $\mathrm{X}$ e de refletância para obterem-se informações sobre a estrutura cristalina das camadas e suas propriedades ópticas. $\mathrm{O}$ arranjo experimental para as medidas de refletância foi adaptado do sistema já existente para realizarem-se medidas de fotorefletância. Uma lâmpada com luz branca é posicionada na frente da entrada de um pequeno monocromador para que um comprimento de onda possa ser selecionado na saída. Esta radiação monocromática é incidida sobre a amostra e é detectada, após reflexão pela superfície, por um detector de silício. Variando a posição da grade de difração do monocromador, produz-se na saída uma radiação monocromática de comprimento de onda variável que possibilita a investigação da refletividade da amostra numa faixa de energia determinada.

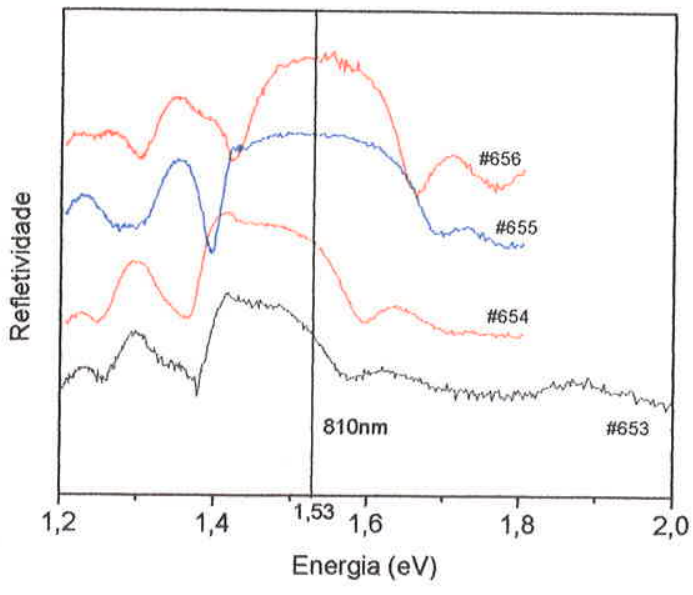

(a)

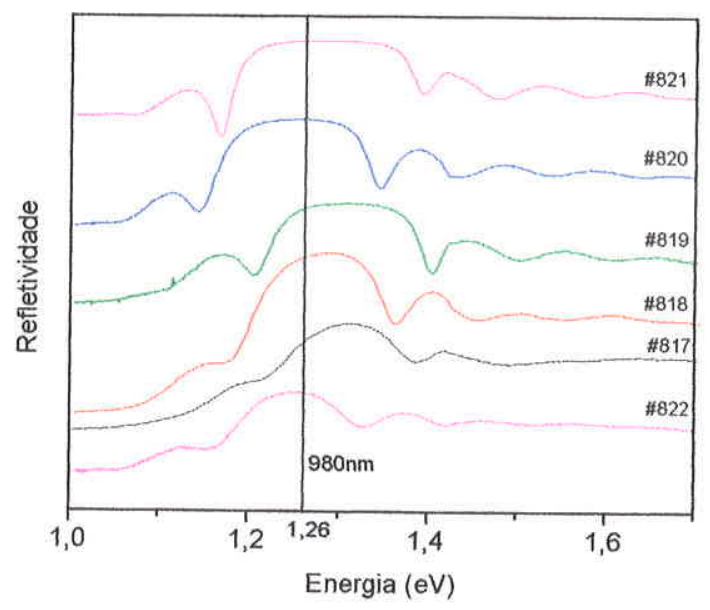

(b)

Figura V-4 - Medidas de refletividade dos espelhos de Bragg; são apresentados os gráficos normalizados da refletividade das amostras (a)do primeiro conjunto, crescido para obter-se um máximo em $\lambda=810 \mathrm{~nm}$ e (b)do segundo conjunto com $\lambda=980 \mathrm{~nm}$.

As medidas de refletividade mostram que os DBRs de AlAs/GaAs (\#655 e \#821) são de melhor qualidade, apresentando uma maior refletividade e uma largura de banda de reflexão maior e mais constante que para as outras amostras. Isso é principalmente devido ao fato que a 
diferença dos índices de refração é máxima entre esses dois materiais e vai diminuindo monotonicamente no caso do segundo conjunto, levando a uma diminuição da refletividade total e de sua largura de banda. Uma refletividade absoluta máxima de $96 \%$ foi obtida para a amostra \#821, o que constitui o valor teórico máximo para estas ligas e o número de pares escolhido.

Da Figura V-4b, vemos que as curvas das amostras \#817 e \#822 possuem o mesmo perfil e se diferenciam apenas pelo deslocamento em relação ao valor nominal do comprimento de onda (980nm), sendo que a amostra crescida pelo método de pseudo-liga (\#822) permanece mais centralizada que a crescida pelo método tradicional de formação da liga. Acreditamos que este deslocamento seja o resultado da variação de um dos fluxos (provavelmente o de gálio) e não de uma diferença intrínseca relacionada com a técnica convencional.

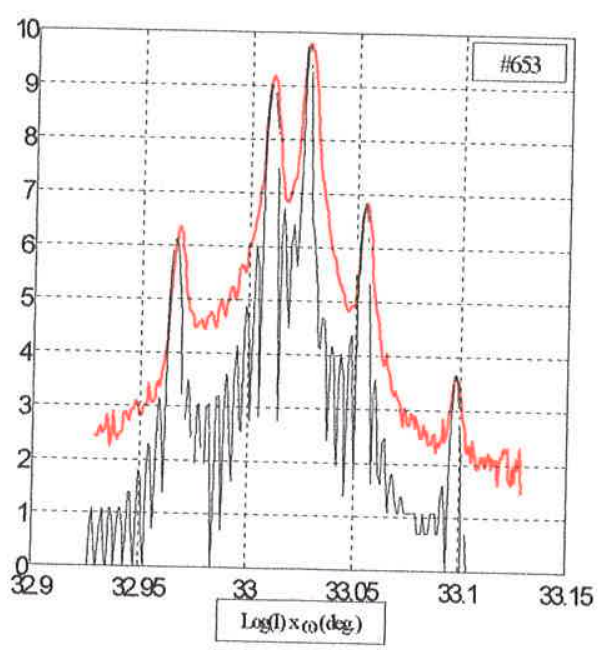

(a)

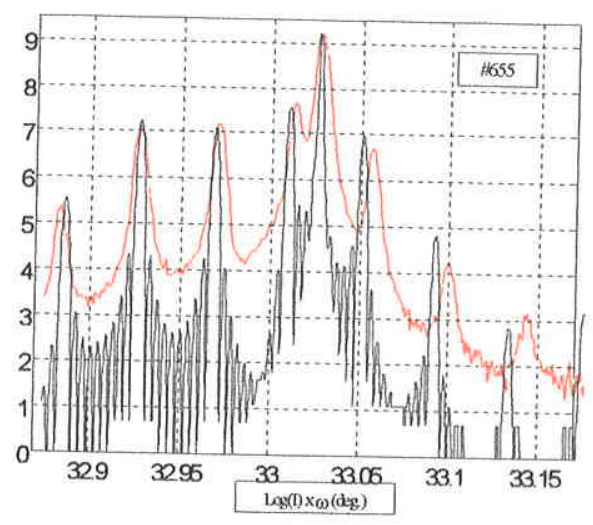

(c)

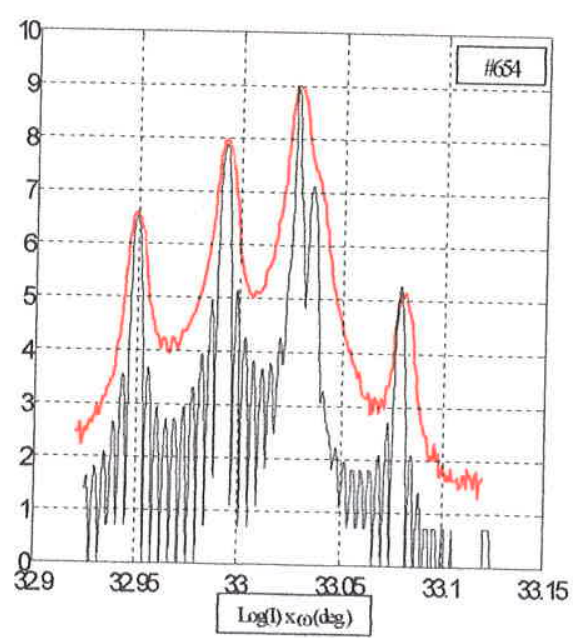

(b)

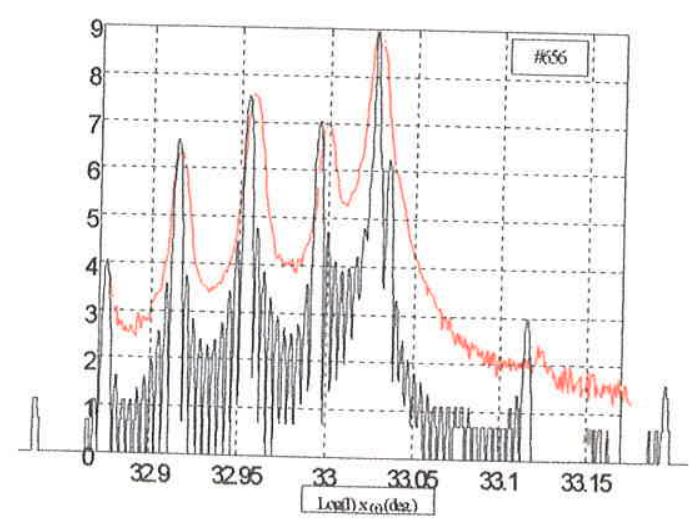

(d)

Figura V-5 - Espectro de raios X das amostras do primeiro conjunto obtido com a configuração de cristal duplo; na ordenada temos o logaritmo do mímero de contagem I e na abcissa o ângulo de espalhamento, em graus; a curva vermelha representa os dados experimentais e a preta a simulação teórica com os dados nominais do
crescimento.

As Medidas de raios X realizadas com o primeiro conjunto mostram que as amostras 
possuem geralmente parâmetros experimentais (liga, espessura das camadas) em bom acordo com os valores nominais. Segundo estes resultados, os parâmetros reais da amostra \#655 (que era a melhor do conjunto a nivel da refletividade absoluta) estão um pouco diferentes dos nominais. Todavia, como a largura de banda é muito grande para esta combinação de ligas, a faixa de refletividade está ainda bem centrada no valor nominal de $\lambda$. Apesar de não termos ainda otimizado completamente este tipo de estrutura, a refletividade total não parece ser influenciada significativamente pela rugosidade microscópica das interfaces, como poderia se esperar de uma estrutura baseada no fenômeno de interferência. Isto é devido ao fato importante que todas as camadas de mesma natureza possuem a mesma largura média na escala do comprimento de onda usado, que é muito maior que qualquer rugosidade gerada pelo crescimento.

No futuro, acreditamos que seja possível produzir espelhos deste tipo, baseados em camadas de AlAs e GaAs para maximizar as características ópticas, possuindo uma refletividade total superior a $99 \%$ para a fabricação de lasers semicondutores a cavidade vertical. O crescimento da estrutura inteira poderá ser executado sobre substratos (311)A para que a dopagem dos espelhos e o crescimento da junção $\mathrm{p}$-n possam ser realizados com um único dopante (o silício). 


\section{CONCLUSÃO}

Este trabalho foi o primeiro a ser realizado em nosso grupo e orientado na produção de camadas epitaxiais para aplicação em dispositivos eletrônicos e optoeletrônicos. Após um extenso estudo do sistema de crescimento e de seu manuseio, as condições de crescimento do GaAs e AlGaAs foram determinadas.

Conseguimos, pela primeira vez no Brasil, dopar uma camada de GaAs do tipo p sem utilizar o elemento berílio, geralmente empregado neste caso. Este fato é muito importante, pois o berílio apresenta vários tipos de problemas relacionados com seu alto coeficiente de difusão no material hospedeiro, além de sua alta toxicidade e dificuldade de ser bombeado fora da câmara de crescimento após seu uso. Este tipo de crescimento, necessitando a evaporação de átomos de silício sobre substratos de GaAs(311)A, é difícil, pois o resultado depende criticamente da razão de fluxo dos elementos III-V e da temperatura do substrato que precisam ser controlados com muita precisão.

Uma outra tentativa de dopagem do tipo p com substratos de $\mathrm{GaAs}(001)$, completamente inédita, foi também um sucesso, pois possibilitou a obtenção de altas densidades de buracos $\left(1,2 \times 10^{18} \mathrm{~cm}^{-3}\right)$. Atribuímos a origem desta dopagem ao complexo $\mathrm{Si}-\mathrm{X}\left(\mathrm{Si}_{\mathrm{As}}-\mathrm{V}_{\mathrm{Ga}}\right)$ responsável pela compensação das amostras altamente dopadas com silício, quando crescidas pela técnica habitual. Nosso novo método ainda apresenta vários problemas relacionados com a baixa mobilidade dos portadores e uma eficiência elétrica em torno de 30\%, mas acreditamos que uma otimização das condições de crescimento possa melhorar significativamente estes resultados.

Realizamos os primeiros testes de crescimento de estruturas de alta mobilidade (HEMT) e alcançamos uma mobilidade de $600.000 \mathrm{~cm}^{2} / \mathrm{Vs}$ a $4,2 \mathrm{~K}$ para uma heterojunção $\mathrm{Al}_{0.3} \mathrm{Ga}_{0.7} \mathrm{As} / \mathrm{GaAs}$, um espaçador de $150 \AA$ e uma densidade eletrônica de $4,2 \times 10^{11} \mathrm{~cm}^{-2}$. Este resultado, o melhor já obtido com uma amostra fabricada no Brasil, é muito promissor, já que o sistema de crescimento não tinha sido preparado para estes fins.

Iniciamos o crescimento, muito promissor também, de espelhos de Bragg que são atualmente usados para a fabricação de lasers semicondutores a cavidade vertical. Obtivemos $96 \%$ de refletividade para 10 pares de camadas $\mathrm{AlAs} / \mathrm{GaAs}$, o que é muito próximo do limite teórico para esta configuração. 


\section{REFERENCIAS}

${ }^{1}$ G.D. O'Clock, L.P. Erikson e T.J. Mattord, Microwaves 20, 8, 101 (1981)

${ }^{2}$ R. Dingle, H. L. Störmer, A.C. Gossard e W. Wiegmann, Apl. Phys. Lett. 37, 805 (1978)

${ }^{3}$ A.Y. Cho e H. C. Casey, Jr., Appl. Phys. Lett. 25, 288 (1974)

${ }^{4}$ A. Y. Cho, R.W. Dixon, H.C. Casey Jr. e R.L. Hartman, Appl. Phys. Lett. 28, 501 (1976)

${ }^{5}$ L. Esaki e R. Tsu, IBM J. Res. Develop.14, 61 (1970) (em A.Y. Cho (ed.), Key Papers in Applied Physics - Molecular Beam Epitaxy, p. 365, AIP Press, Nova York, 1994)

${ }^{6}$ A.Y. Cho, M.B. Panish e I. Hayashi, Proc. Symp. GaAs and Related Compounds 2, 18 (1970) (em A.Y. Cho (ed.), Key Papers in Applied Physics - Molecular Beam Epitaxy, p. 63, AIP Press, Nova York, 1994)

${ }^{7}$ A.Y. Cho, J. Appl. Phys. 46, 1733 (1975) (em A.Y. Cho (ed.), Key Papers in Applied Physics Molecular Beam Epitaxy, p. 307, AIP Press, Nova York, 1994)

${ }^{8}$ A.Y. Cho, Appl. Phys. Lett. 19, 467 (1971) (em A.Y. Cho (ed.), Key Papers in Applied Physics - Molecular Beam Epitaxy, p. 370, AIP Press, Nova York, 1994)

${ }^{9}$ A.Y. Cho, J. Appl. Phys. 41, 2780 (1970) (em A.Y. Cho (ed.), Key Papers in Applied Physics Molecular Beam Epitaxy, p. 245, AIP Press, Nova York, 1994)

${ }^{10}$ Fonte: Molecular Beam Epitaxy - Varian, thin film technology division, 3550 Basset street, Santa Clara, Califórnia

${ }^{11}$ C.L. Phillips e R.D. Harbor, "Feedback Control Systems", 1991

12 J.A. Stroscio e W.J. Kaiser, "Scanning Tunneling Microscope", Methods of Experimental Physics Vol 27, p.38, 1993

13 em ref. 12, pg. 06

${ }^{14}$ E.M. Machado e A.A. Quivy, "Sistema computacional para a automatização do processo de crescimento de semicondutores por MBE", apresentação oral no XII Congresso de Iniciação Científica e Tecnologia em Engenharia, 13-16 de dezembro de 1994, São Carlos, SP

${ }^{15}$ D.I. O'Connor, B.A. Sexton, R.St.C. Smart(eds.), "Surface Analysis Methods in Materials Science", Springer-Verlag, pg.67 (1992)

${ }^{16}$ M.A. Herman e H. Sitter, "Molecular Beam Epitaxy - Fundamentals and Current Status", Springer-Verlag, $2^{\text {a }}$ ed., pg.3 (1996)

${ }^{17}$ M. Wutz, H. Adam, W. Walcher, "Theory and Practice of Vacuum Technology", VIEWEG, 
Germany, pg. 278, 1989

${ }^{18}$ em ref. 17 , pg. 417

${ }^{19}$ em ref. 17, pg. 425

${ }^{20}$ Apostila "Curso de Tecnologia do Vácuo", Instituto de Física da USP, pg. 22, 1992

${ }^{21}$ Manual de instalação e operação "Modline Plus - Infrared Pirometer", sec. 07, 4a ed., junho, 1990

${ }^{22}$ EPI Application Note, "A Heatable, Low-Strain Viewport for Use in MBE", October, 1993

23. Manual Varian "Molecular Beam Epitaxy - GEN II MOD", vol. III, sec. 1, dec., 1986

${ }^{24}$ E.H.C. Parker (ed.), "The Technology and Physics of Molecular Beam Epitaxy", pg. 18, Plenum, Nova York, 1985

${ }^{25}$ W. Steckelmacher, Rep. Prog. Phys. 49, 1083 (1983)

${ }^{26}$ em ref. 16 , pg. 36

${ }^{27}$ EPI components for MBE - 1993 product guide, Sait Paul, Minnesota 55101 U.S.A.

${ }^{28}$ J.N. Miller, J. Vac. Sci. Technol. B 10, 803 (1992)

${ }^{29}$ G.W. Turner, B.A. Nechay e J.S. Eglash, J. Vac. Sci. Technol. B 8, 283 (1990)

${ }^{30}$ R. Fernandes, A. Harwit e D. Kinell, J. Vac. Sci. Technol. B 12, 2, 1023 (1994)

3 A.P. Lima, "Crescimento e Caracterização de semicondutores crescidos por MBE", dissertação de mestrado do Instituto de Física da USP, São Paulo, pg.56 (1994)

${ }^{32}$ H.K. Lee, "Estudo do contato metal-semicondutor em GaAs e sua contribuição na construção de MESFET", dissertação de mestrado da Escola Politécnica da USP, São Paulo, apêndice III (1990)

${ }^{33}$ K.S.A. Butcher, R.J. Egan, T.L. Tansley e D. Alexiev, J. Vac. Sci. Technol. B 14, 1, 152 (1996)

${ }^{34}$ Y.G. Chai, Y-C. Pao e T. Hierl, Appl. Phys. Lett. 47, 12, 1327 (1985)

${ }^{35}$ EPI Application Note, "The EPI Uniblock: Excellente Performance and Convenience with a Non-bonded Substrate Holder", August, 1996

${ }^{36}$ A. Y Cho e J.R. Arthur, Prog. Solid-State Chem. 10, 157 (1975)

${ }^{37}$ B.A. Joyce, Rep. Progr. Phys. 37, 363 (1974)

${ }^{38}$ J.R.Arthur and T.R. Brown, J. Vac. Sci. Technol. 12, 200 (1975)

${ }^{39}$ C.T. Foxon ad B.A. Joyce, Surf. Sci. 64, 293 (1977)

${ }^{40}$ R. Dingle, W. Wiegmann and C.H. Henry, Phys. Rev. Lett. 33, 827 (1974) 
${ }^{41}$ D. Leonard, M. Krishnamurthy, C.M. Reaves, S.P. Denbaars e P.M. Petroff, Appl. Phys. Lett. 63, 3203(1993)

42 J.A. Venables, G.D.T. Spiller, M. Hanbuecken, Rep. Prog. Phys. 47, 399 (1984)

${ }^{43}$ C. Kittel, "Introduction to Solid State Physics", 7" ed., pg. 21, Wiley, Nova York, 1996

${ }^{44}$ J. Singh, "Semicondctor Optoeletronics - Physics and Technology", McGraw-Hill internatinal editions, Nova York, pg. 09, 1995

${ }^{45}$ em ref. $44, p g .521$

${ }^{46}$ J.R. Arthur, J. Phys . Chem. Solids 28, 2257 (1968)

${ }^{47}$ J.R. Arthur, Surf. Sci. 43, 449 (1974)

${ }^{48}$ S. Martini, "Propriedades Óticas de Poços Quânticos de InGaAs crescidos por MBE sobre Substratos Desorientados de GaAs", dissertação de mestrado do Instituto de Física da USP, São Paulo, pg.10 (1997)

${ }^{49}$ B.A. Joyce, Rep. Prog. Phys. 48, 1637 (1985)

${ }^{50}$ N.W. Ashcroft e N.D. Mermin, "Solid State Physics", Saunders College Publishing Intenational Edition, pg. 86, 1976

${ }^{5 !}$ A. Y. Cho, Thin Solid Films 100, 291(1983)

52 em ref. 43 , cap. 1

${ }^{53}$ I. Hernández-Calderón e H. Höchst, Phys. Rev. B 27, 8, 4961 (1983)

${ }^{54}$ J. H. Neave, B.A. Joyce, P.J. Dobson e N. Norton, Appl Phys. A 31, 1 (1983)

${ }^{55}$ A.Y. Cho, J. Appl. Phys. 41, 2780 (1970)

${ }^{56}$ A. Kahn, Surf. Rev. Lett. 3, 4, 1579(1996)

${ }^{57}$ W.A. Harrison, J. Vac. Sci. Technol. 16, 1492 (1979)

${ }^{58}$ M.D. Pashley, Phys. Rev. B 40, 1048 (1989)

${ }^{59}$ H.H. Farrel, J.P. Harbison and L.D. Peterson, J. Vac. Sci. Technol. B5 (5), 1482 (1987)

${ }^{60}$ J.J. Harris and B.A. Joyce, Surf. Sci. 103, L90 (1981)

${ }^{61}$ C.E.C Wood, Surf. Sci. Lett. 108, L441 (1981)

62 J.H. Neave, P.J. Dobson, B.A. Joyce e Jin Zhang, Appl. Phys. Lett. 47, 2, 100 (1985)

${ }^{6.3}$ B.A. Joyce, P.J. Dobson, J.H. Neave, K. Woodbridge, J. Zhang, P.K. Larsen e B. Boelger, Surf. Sci. 168, $423(1986)$

${ }^{64}$ J.H. Neave, B.A. Joyce, P.J. Dobson, Appl. Phys. Lett. A 34, 179 (1984)

${ }^{65}$ B.F. Lewis, F.J. Grunthaner, A. Madhukar, T.C. Lee, R. Fernandes, J. Vac. Sci. Technol. B 3, 
$1317(1985)$

${ }^{66}$ F.Y. Juang, P.K. Bhattacharya e J. Singh, Appl. Phys. Lett. 48, 290 (1986)

${ }^{67}$ P.J. Dobson, B.A. Joyce, J.H. Neave e J. Zhang, J. Cryst. Growth 81, 1, (1987)

${ }^{68}$ B.F. Lewis, T.C. Lee, F.J. Grunthaner, A. Madhukar, R. Fernandez, J. Maserjian, J. Vac. Sci. Technol. B 2, 419, (1984)

${ }^{69}$ B.F. Lewis, F.J. Grunthaner, A. Madhukar, T.C. Lee, R. Fernandez, J. Vac. Sci. Technol. B 3, $1317(1985)$

${ }^{70}$ T. Shitara, D.D. Vvedensky, M.R. Wilby, J. Zhang, J.H. Neave e B.A. Joyce, Phys. Rev. B 46, 11, $6825(1992)$

${ }^{71}$ J. Sudijono, M.D. Johnson, C.W. Snyder, M.B. Elowitz and B.G. Orr, Phys. Rev. Lett. 69 (19), $2811(1992)$

${ }^{72}$ C. Orme and B.G. Orr, Surface Review and Letters 4 (1), 71 (1997)

${ }^{73}$ J.M. Moison, C. Guille, F. Houzay, F. Barthe e M. Van Rompay, Phys. Rev. B 40, 9, 6149 (1989)

${ }^{74}$ K. Radhakrishnan, S.F. Yoon, R. Gopalakrishnan e K.L. Tan, J. Vac. Sci. Technol. A 12, 4, 1124 (1994)

${ }^{75}$ R. Köhrbrück, S. Munnix, D. Bimberg, E.C. Larkins e I.S. Harris Jr., Appl. Phys. Lett. 54, 7, $623(1989)$

${ }^{76}$ J. Dabrowski e M. Scheffler, Phys. Rev. Lett. 60, 2183 (1988)

${ }^{77}$ D. Bimberg, D. Mars, J.N. Miller, R. Bauer e D. Oertel, J. Vac. Sci. Technol. B 4, 4, 1014 (1986)

${ }^{78}$ M.A. Herman, D. Bimberg e I. Christen, J. Appl. Phys. 70R1, 2 (1991)

${ }^{79}$ J.H. Neave, B.A. Joyce, P.J. Dobson e N. Norton, Appl. Phys. A 31, 1 (1983)

${ }^{80}$ F. Turco, J. Massies e J.P. Contour, Revue Phys. Appl. 22, 827 (1987)

${ }^{81}$ M. Tanaka e H. Sakaki, Superlattices and. Microstrutures. 4, 2, 237 (1988)

${ }^{82}$ M. Tanaka e H. Sakaki, J. Crist. Growth 81, 153 (1987)

8.3 V.C. Montanher, "Propriedades Óticas de Heteroestruturas Semicondutoras de GaAs/AlGaAs", dissertação de mestrado do Instituto de Física da USP, São Paulo, 1997

${ }^{84}$ P.M. Petroff, R.C. Miller, A.C. Gossard e W. Wiegmann, Appl. Phys. Lett. 44, 2, 217 (1984)

${ }^{85}$ L.E, Oliveira, Phys. Rev. B 38, 10641 (1988)

${ }^{86}$ J. Sudijono, M.D. Johnson, C.W. Snyder, M.B. Elowitz e B.G. Orr, Phys. Rev. Lett. 69, 2811 
(1992)

${ }^{87}$ C. Orme e B.G. Orr, Surf. Rev, Lett. 4, 1, 71 (1997)

${ }^{88}$ A. Cho (ed.), "Key papers in Apllied Physics - Molecular Beam Epitaxy", AIP Press, Nova York, cap. 4, pg. 305, 1994, ref. A. Y. Cho e I. Hayashi, Met. Trans. 2, 777 (1971)

${ }^{89}$ A. Y. Cho, C.N. Dunn, R.L. Kuvas e W.E. Schroeder, Appl. Phys, Lett. 25, 224 (1974)

${ }^{90}$ J.V. DiLorenzo, W.C. Niehaus e A.Y. Cho, J. Appl. Phys 50, 951 (1979)

${ }^{91}$ C.E.C. Wood e B.A. Joyce, J. Appl. Phys. 49, 4854 (1978)

${ }^{92}$ A.Y. Cho, J. Vac. Sci. Technol. 8, S31 (1971)

${ }^{93}$ B.A. Joyce e C.T. Foxon, Jpn. J. Appl. Phys. 16, 17 (1982)

${ }^{94}$ M. Ilegems, J. Appl. Phys. 48, 1278 (1977)

${ }^{95}$ Y. Horikoshi, A. Fisher, E.F. Shubert e K. Ploog, Jpn. J. Appl. Phys. 25, 1566(1986)

${ }^{96}$ R. Murray, R.C. Newman, M.J.L. Sangster, R.B. Beall, J.J. Harris, P.J. Wright, J. Wagner e M. Ramsteiner, J. Appl. Phys. 66, 6, 2589 (1989)

${ }^{97}$ R.C. Newman, Semicond. Sci. Technol. 9, 1749 (1994)

${ }^{98}$ J.H. Neave, P.J. Dobson, B.A. Joyce e jen Zhang, Appl. Phys. Lett. 47, 100(1985).

${ }^{99}$ Y.G. Chai e R. Chow, Appl. Phys. Lett. 39, 800(1981).

${ }^{100}$ W.I. Wang, E.E. Mendez, T.S. Kuan e L. Esaki, Appl. Phys. Lett. 47, 8, 826 (1985)

${ }^{101}$ T. Takamori, T. Fukunaga, J. Kobayashi, K. Ishida e H. Nakashima, Jpn. J. Appl. Phys. 26, 7, 1097 (1987)

${ }^{102}$ W.Q. Li, P.K. Bhattacharya, S.H. Kwork e R. Merlin, J. Appl. Phys. 72, 7, 3129 (1992)

${ }^{103}$ K. Agawa, K. Hirakawa, N. Sakamoto, Y. Hashimoto e T. Ikoma, Appl. Phys. Lett. 65, 9, $1171(1994)$

${ }^{104}$ N. Sakamoto, K. Hirakawa e T. Ikoma, Appl. Phys Lett. 67, 10, 1444 (1995)

${ }^{105}$ Y. Hsu, W.I. Wang e T.S. Kuan, J. Vac. Sci. Technol. B 12, 4, 2584 (1994)

${ }^{106}$ K. Agawa, K. Hirakawa, N. Sakamoto, Y. Hashimomto e T. Ikoma, Appl. Phys. Lett. 65 (9), 1171(1994).

${ }^{107}$ N. Sakamoto, K. Hirakawa e T. Ikoma, Appl. Phys. Letl. 67 (10), 1444(1995).

${ }^{108}$ R. Nötzel, L. Däweritz e K. Ploog, Phys. Rev. B 46 (8), 4736(1992).

${ }^{109}$ A.M. Ceschin, A.A. Quivy, E.C.F. da Silva, J.A.N.T. Soares, R. Enderlein, L.M.R. Scolfaro, I.R. Leite, E.A. Meneses e J.B.B. Oliveira, Superlattices and Microstmuctures 11, 333(1994). ${ }^{110}$ A.S. Tabata, A.M. Ceschin, A.A. Quivy, A. Levine, J.R. Leite, R. Enderlein, J.B.B. Oliveira, 
E. Laureto e J.L. Gonçalves, Material Science \& Engineering B 35, 401(1995).

${ }^{111}$ Y.A. Pusep, M.T.O. Silva, S.W. da Silva, J.C. Galzerani, L.M.R. Scolfaro, R. Enderlein, A.A. Quivy, A.P. Lima, e J.R. Leite, Phys. Rev. B 54 (19), 13927(1996)

112 A. Levine, E.C.F. da Silva, L.M.R. Scolfaro, D. Beliaev, A.A. Quivy, R. Enderlein e J.R. Leite, "Spatially direct recombinations observed in multiple delta-doped GaAs layers", Superlattices and Microstructures, in press (1997).

${ }^{113}$ M. Henini, P.J. Rodgers, P.A. Crump, B.L. Gallagher e G. Hill, J. Cryst. Growth 150, 451 (1995)

${ }^{114}$ A.A. Quivy, M. Frizzarini, E.C.F. da Silva, A.L. Sperandio e J.R. Leite, Braz. J. Phys. 27/A, 4, (1997)

${ }^{115}$ J.H. Neave, B.A. Joyce e P.J. Dobson, Appl. Phys. Lett. A 34, 179 (1984)

${ }^{116}$ R. Dingle, H.L. Störmer, A.C. Gossard e W. Wiegmann, Appl. Phys. Lett. 33, 665 (1978)

${ }^{117}$ H.L., Störmer e W.T. Tsang, Appl. Phys. Lett. 36, 8, 685 (1980)

${ }^{118}$ T.J. Drummond, H. Morkoç e A.Y. Cho, J. Appl. Phys.52, 1380 (1981)

119 E.H.C. Parker (ed.), "The technology and Physics of Molecular Beam Epitaxy", Plenum Press, Nova York, pg. 186, 1985

${ }^{120}$ K. Ploog, J. Cryst. Growth 81, 304 (1987)

${ }^{121}$ E.F. Shubert, Y. Horikoshi e K. Ploog, Phys. Rev. B 32, 1085 (1985)

122 J. Singh, "Semiconductor Optoeletronics - Physics and Technology", McGraw-Hill, New York, 1995

${ }^{12.3}$ R.S. Geels, S.W. Corzine e L.A. Coldren, IEEE J. Quantum Electron. 27, 6, 1359(1991)

${ }^{124}$ N.C. Frateschi, "Optoeletronic Devices Based on Low Threshold InGaAs/GaAs Quantum Well Lasers Grown on Structured Substrates", dissertation presented to the Faculty of the Graduate School - University of Southern California in partial fulfillment of the requirement for the degree Doctor of Philosophy (Electrical Engeneering), August(1993)

${ }^{125}$ J.L. Jewell, J.P. Harbiison, A. Scherer, Y.H. Lee, and L.T. Florez, IEEE J. Quantum Electron. $27,6,1332(1991)$

${ }^{126}$ G.R. Fowles, "Introduction to Modern Optics", Rinehart and Winston, INC, 1975

${ }^{127}$ K.L. Lear e R.P. Schneider Jr., Appl. Phys. Lett. 68, 5, 605(1996)

${ }^{128}$ M.G. Peters, D.B. Young, F.H. Peters, B.I. Thibealt, J.W. Scott, S.W. Corzine, R.W. Herrick e L.A. Coldren, Proc. SPIE 2147, 1(1994) 